University of Rhode Island

DigitalCommons@URI

Open Access Dissertations

2017

\title{
The Blame Game: The Effect of Recommendation Context on Product Outcome Attributions
}

Stephanie L. Jacobsen

University of Rhode Island, Stephbarnes6@gmail.com

Follow this and additional works at: https://digitalcommons.uri.edu/oa_diss

\section{Recommended Citation}

Jacobsen, Stephanie L., "The Blame Game: The Effect of Recommendation Context on Product Outcome Attributions" (2017). Open Access Dissertations. Paper 652.

https://digitalcommons.uri.edu/oa_diss/652

This Dissertation is brought to you for free and open access by DigitalCommons@URI. It has been accepted for inclusion in Open Access Dissertations by an authorized administrator of DigitalCommons@URI. For more information, please contact digitalcommons-group@uri.edu. 
THE BLAME GAME: THE EFFECT OF RECOMMENDATION CONTEXT ON PRODUCT OUTCOME ATTRIBUTIONS

BY

STEPHANIE L. JACOBSEN

A DISSERTATION SUBMITTED IN PARTIAL FULFILLMENT OF THE REQUIREMENTS FOR THE DEGREE OF

DOCTOR OF PHILOSOPHY

IN

BUSINESS ADMINISTRATION

UNIVERSITY OF RHODE ISLAND 


\section{DOCTOR OF PHILOSOPHY DISSERTATION}

OF

STEPHANIE L. JACOBSEN

\section{APPROVED:}

Dissertation Committee:

Major Professor Christy Ashley

Hillary A. Leonard

Ian Reyes

Nasser H. Zawia

DEAN OF THE GRADUATE SCHOOL

UNIVERSITY OF RHODE ISLAND

2017 


\begin{abstract}
Written online communications between consumers have emerged to play an important role in the consumer decision-making process (Cheung and Lee 2012). Though electronic word of mouth (eWOM) has been studied widely, less is known about how reviews and, more specifically, product recommendations, affect attribution of credit or blame for a post purchase outcome. Attribution is important because it can affect repurchase behavior, loyalty, and word of mouth. Therefore, this dissertation experimentally examines how recommendation context affects attribution of credit or blame to consumers, reviewers, and retailers. It tests the thesis that context factors that are independent of the product recommendation can affect how consumers assign responsibility for the product's performance.
\end{abstract}

Study 1 demonstrates that, relative to offline recommendations from friends, retailers get less blame for a poorly performing product when recommendations are online. In contrast to the existing literature, the results suggest the source of the recommendation can affect who consumers blame or assign credit for the purchase outcome. The results indicate that online recommendations may create a buffer for the retailer against blame for a negative purchase outcome, and may garner the retailer more credit for a positive purchase outcome.

In Study 2, reviews from friends and strangers are communicated online and the sole focus is negative purchase outcomes. Identification with the firm was measured as another factor that can affect attribution of blame. While there were not significant differences between blame assigned to the retailer or reviewer based on the source of the review, identification with the retailer helped protect the retailer from blame 
following a negative purchase outcome, regardless of the review source. These results have implications for the literature, as there is debate over whether feeling close to a retailer can protect or hurt the retailer during a negative experience.

Study 3 focuses on online reviews from strangers. It tests whether incentivized reviews undermine the effects of identification with the retailer on attribution of blame to the retailer. The results suggest incentivized reviews are a boundary condition to the effect of identification that is found in Study 2. This finding is consistent with previous research that shows when consumers feel strongly that they have been wronged by a retailer, identifying with the retailer increases, instead of decreases, blame. This also adds incentivizing reviewers as a new contributing factor for the change in attribution by consumers that identify with the firm.

The dissertation concludes with a discussion of the role of reviews in postpurchase processes and the theoretical and managerial implications of retailers' strategies related to posting online reviews, considering contextual factors such as whether the retailer has earned strong identification from its consumers and whether the retailer offers incentives for reviews. 


\section{ACKNOWLEDGMENTS}

I would like to thank my major advisor, Christy Ashley for her guidance, commitment and support during the writing of this dissertation. She somehow managed to make this process enjoyable and I have learned so much from her. There is no way to thank her for what she has given me. All of the faculty at the University of Rhode Island, specifically my marketing professors and my committee, have provided me with the knowledge and tools that I need to succeed and their commitment to my educational success has both inspired me, and allowed me to write this dissertation.

I am forever grateful for the love, encouragement and motivation from my entire family. I consider myself to be unimaginably lucky in having the most amazing family who has supported me throughout this journey. I would not have pursued a doctorate, never mind completed a dissertation without the influence and example of my mother. I am honored to be following in her footsteps. This dissertation is dedicated to her. Though I am following a path set forth by my mother, I would not be who I am without my father. His love and support has always allowed me to believe that I can do anything I set my mind to. I believe there is no greater gift a father can give a daughter. I would also not be where I am today without my brother whose love of reading and learning inspired me to do the same. To my husband, who unselfishly supported my pursuit of a doctorate, your hard work and dedication to your career motivated me to work hard and to make you proud. I love you with all my heart.

I am a combination of the many great people who have been a part of my life. Grandparents, teachers, friends and family have all led me down this path and were instrumental in the writing and completion of this dissertation. 


\section{TABLE OF CONTENTS}

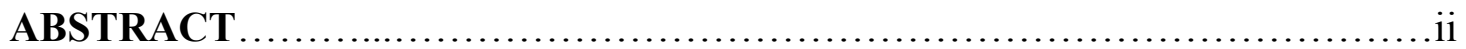

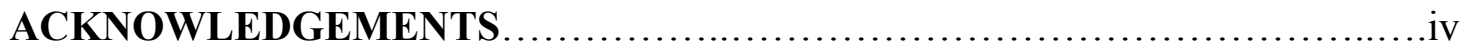

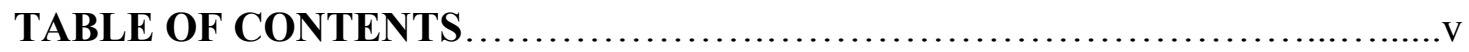

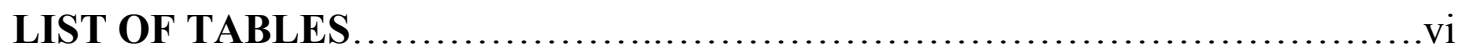

LIST OF FIGURES....................................................

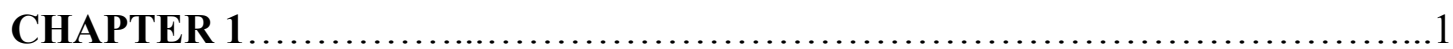

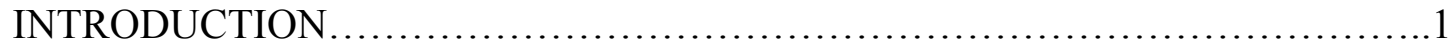

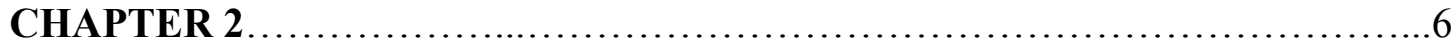

REVIEW OF LITERATURE............................................6

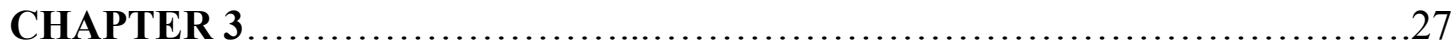

HYPOTHESES DEVELOPMENT AND MODEL ..............................27

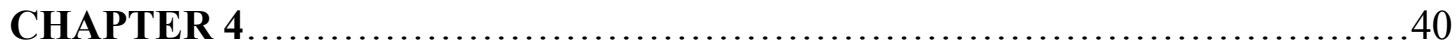

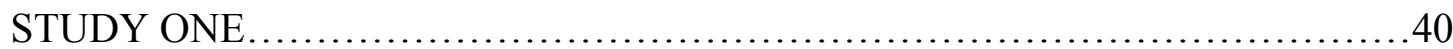

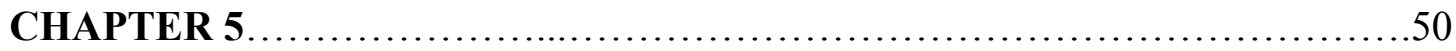

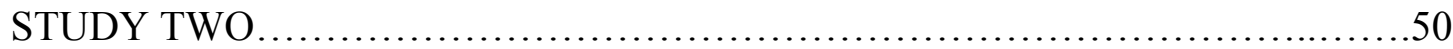

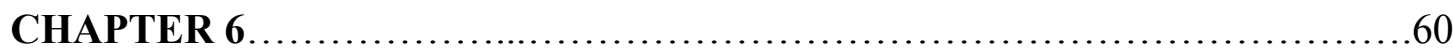

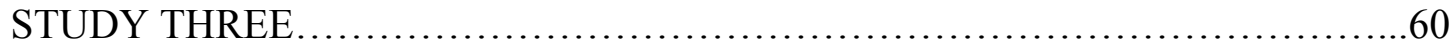

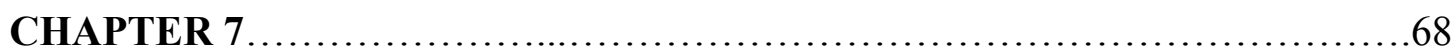

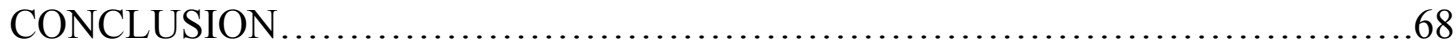

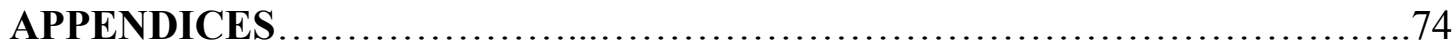

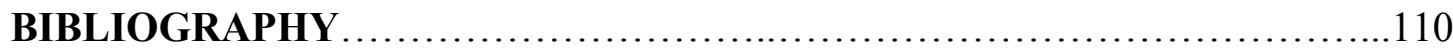




\section{LIST OF TABLES}

TABLE

PAGE

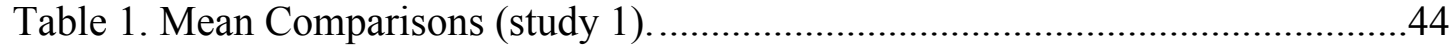

Table 2. Reasons for friends/reviewers making positive recommendations ...............47

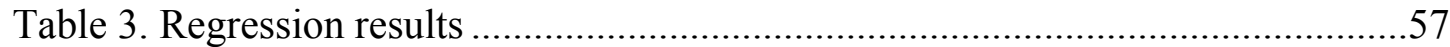




\section{LIST OF FIGURES}

\section{FIGURE}

PAGE

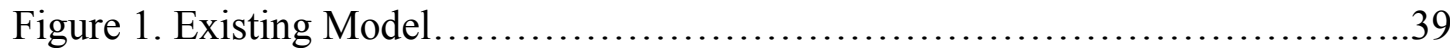

Figure 2. New Model.................................................... 39

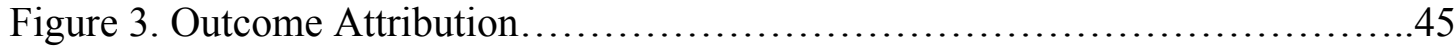

Figure 4. Attribution of blame to the retailer...................................65 


\section{CHAPTER 1}

\section{INTRODUCTION}

\section{Statement of the Problem}

Does the context of product reviews affect who gets credit or blame for a product's performance? Previous research has studied many contextual factors, like whether reviews are verbal or written, whether a review is relevant, or ambiguous, or whether people engage in information sharing behavior (e.g., Berger \& Milkman, 2012; Berger \& Schwartz, 2011; Cheema \& Kaikati, 2010; Wojnicki \& Godes, 2011). The typical outcomes that have been studied are product evaluations or product preferences, and research on the relationship between reviews and post-purchase behavior is focused on product returns (Minnema, Bijmolt, Gensler, \& Wiesel, 2016).

A question remains about whether recommendations can impact attributions of causality for a product's performance. Attributions of causality, defined as cause and effect patterns that enable individuals to make inferences in order to establish the driver of a given outcome, are important because they have been shown to affect consumer attitudes and behaviors toward the product and the retailer that sold the product (increased positive WOM, loyalty, trust, repurchase behavior) (Curren \& Folkes, 1987; Folkes, 1988; Tsiros, Mittal, \& Ross, 2004; Swanson \& Kelley, 2001).

To address this gap in the literature, the research project experimentally examines how the word-of-mouth channel (offline, electronic) interacts with the valence (positive, negative) of the purchase outcome (Study 1); how the relationship 
with the electronic word-of-mouth source (friend, stranger) interacts with consumer identification with the retailer (Study 2); and how knowledge that the electronic wordof-mouth source was incentivized interacts with retailer identification (Study 3); to affect consumers' attributions of credit or blame for product performance.

For the purposes of these studies, the online retailer is operationalized as a major brand that would be positively associated with a specific purchase on their site, not a brand purchased from them. For instance, when you buy Purina dog food from Amazon, you may credit Purina for a quality purchase instead of Amazon. However, when you buy a scarf from Macy's, you may not know the brand, and are more likely to credit Macy's with the purchase. As retailer identification is important in the second and third studies, using a retailer who represents the overall products being sold is important. Thus, use of marketplace sites like Amazon, eBay, and Etsy are not considered for these three studies.

\section{Justification for and Significance of the Study}

Product reviews and recommendations from customers are important to marketers because these reviews can shape consumer decision-making and product diffusion (e.g. Anderson \& Magruder, 2012; Berger, 2014). The impact of reviews is amplified in an online environment, which allows consumers to view product information and opinions from a wider range of friends and strangers (Jones, 2013; Packard \& Berger, 2015; You, Vadakkepatt, \& Joshi, 2015). In fact, according to a study by BrightLocal (2014), 88\% of consumers report they trust online reviews as much as a personal recommendation from a friend or family member. Perhaps as a result, word-of-mouth (WOM) and electronic word-of-mouth (eWOM) have been 
studied extensively in the literature (see Appendix A). Although the impact of reviews on consumer evaluations and purchases has been established, less is known about how the type of review impacts post-purchase evaluations. These post-purchase evaluations are important, as they affect consumer relationships and repurchase behavior (Gilly, 1987; Swanson \& Kelley, 2001; Grewal, Roggeveen, \& Tsiros, 2008).

\section{Contributions of the Research}

The research advances knowledge and makes several important contributions to marketing theory and practice. Specifically:

1. This research addresses a gap in WOM knowledge. It provides evidence that reviews' contextual factors can impact who gets credit or blame for product performance.

2. The use of controlled experiments allowed for the isolation of the causal effects of contextual factors of reviews in varying conditions.

3. Results from the studies build a link between social identity theory and attribution theory.

4. The results are actionable, and they should help managers improve communications about reviews and use reviews, and identifiers from social media, more strategically.

\section{Organization of the Dissertation Studies}

Chapter 2 begins with a review of the relevant literature, namely Attribution Theory, Word of Mouth (WOM), Electronic Word of Mouth (eWOM), Social Identity Theory, and Identification with the Retailer. This is followed by the hypotheses development in chapter 3 . 
Chapter 4 outlines Study 1, which examines the effect of review source on outcome attribution when a product is recommended by either a friend (offline) or a stranger (online). The outcome is attributed to either the retailer, a friend or online reviewer, or self. Importantly, attribution theory states that a cause can be attributed to an external factor (retailer, friend or online reviewer) or an internal factor (self) (Weiner, 1980). The attribution literature typically cites the retailer as the main recipient of purchase attribution (Curren \& Folkes, 1987), however when a product is recommended by a friend or a stranger, it is possible they could also receive some of the blame or credit (Weiner, 1980). The findings of Study 1 demonstrate a distinct desire for consumers to avoid blame for an unsuccessful purchase and credit themselves for a successful one. They also show that consumers will blame a third party (online reviewer), lessening the blame the retailer experiences.

Chapter 5 discusses Study 2, which focuses on negative product outcomes, and examines whether the source of the online review (friend or stranger) and consumer identification with the retailer interact to affect consumer attribution of blame. The literature demonstrates that identification with the retailer by a consumer can protect the retailer from blame (Einwiller, Fedorikhin, Johnson, \& Kamins, 2006; Schmalz and Orth, 2012). Therefore, this study seeks to demonstrate that in an online review context, retailer identification will protect the retailer and increase blame to the friend or stranger. The findings of Study 2 demonstrate that when a consumer identifies with the retailer, the blame the retailer receives is lessened and blame to the friend or stranger is greater. 
Chapter 6 focuses on Study 3, which extends the first two studies and examines what happens when a reviewer is compensated for the review. It focuses on reviews from strangers because the hypotheses from Studies 1 and 2 suggest reviews from strangers may offer retailers more protection from blame than friends. Study 2 did not find a difference between friends and strangers in the context of online reviews, and the ability to identify friends in online reviews is still somewhat rare. The literature shows that retailers have been using incentives to increase the numbers of reviews on their sites (Pinch \& Kesler, 2011; Cabral \& Li, 2015). What has not been looked at is whether this incentivizing increases or decreases the blame to the reviewer. On the one hand, the reviewer has been influenced and may be biased. Importantly though, this bias was caused by the retailer, and therefore the consumer may feel the retailer has unjustly influenced the reviewers, and betrayed the consumer. The results of study 3 show that consumers felt betrayed by retailers when the reviewer was incentivized. This effect was more pronounced when a consumer identified with the retailer, as if the retailer deceived them. This section concludes with a discussion of the findings and implications.

Chapter 7 concludes by summarizing the overall results of the three studies. This is followed by the implications these findings have on theory, as well as how these results should be used in the marketplace. 


\section{CHAPTER 2}

\section{REVIEW OF LITERATURE}

This chapter is organized into six sections. The first part describes Attribution Theory, while the second part provides background on Word of Mouth. Next, the Internet and electronic Word of Mouth (eWOM) are discussed. Social Identity Theory and Retailer Identification are also discussed, since they provide a theoretical base for the development of hypotheses.

\section{Attribution Theory}

Attribution theory was introduced in Fritz Heider's (1958) book, the Psychology of Interpersonal Relations, to explain why and how people gather information to form causal judgments. Harold Kelley (1967) explored the idea of attribution, categorizing the causal nature of occurrences into low factors (attributing them internally/personally) or high factors (attributing them to situations). Attribution theory holds great significance for the field of consumer behavior as marketers strive to understand how consumers decide who is responsible for their experiences and interactions, and how these decisions can have an effect on repurchasing, word of mouth and brand loyalty (e.g. Folkes, 1988; Grewal, Roggeveen, \& Tsiros, 2008).

Previous research has found that attribution is based on three key factors: causal stability, causal locus and causal controllability (Weiner, 1980). While all of these contribute to how consumers make attributions, Folkes (1984) found that the 
dominant attribution dimension for satisfaction is locus of causality. Consumers primarily are concerned with where the responsibility lies. Causality is usually examined as something that is either internal or external. When we attribute our satisfaction or dissatisfaction with an internal cause, we acknowledge we could have or did do something to affect the outcome. In contrast, while internal causality would lead to the consumer feeling responsible for the outcome, external causality would hold the retailer responsible for the outcome in a purchase situation (Weiner, 1980). Therefore, in a purchasing context, unless the consumer specifically caused an unsuccessful outcome (possibly by choosing a cheaper product, therefore ending up with something of lesser quality, or by not taking the time to research or explore other options) the retailer will receive the blame.

Existing literature has shown evidence of retailer attribution for purchases regardless of the outcome (Curren \& Folkes, 1987). Some research has focused on the attribution of dissatisfaction (Landon \& Emery, 1975; Valle \& Wallendorf, 1977), while others have looked at the attribution of satisfaction (Muller, Tse, \& Venkatasubramaniam, 1991; Tsiros, et al., 2004) and the effect of attribution on repurchase intentions (Grewal, Roggeveen, \& Tsiros, 2008). Previous research points to seller/retailer attribution for negative outcomes associated with a purchase, but internal/self-attributions for positive outcomes associated with a purchase (See Appendix B for a review). Thus, consumers are quick to give themselves credit for a successful purchase and yet hold the retailer responsible when something goes wrong. This self-serving bias protects the consumer in either outcome context, while negatively impacting the retailer. 
Research has not focused on the influence of a third party that could contribute to the attribution of causality for a purchase outcome. Research shows that word-ofmouth communications, with amplified reach in social media environments, impacts consumer decision-making (Pentina, Bailey, \& Zhang, 2015), but it is not clear if it impacts post-purchase evaluations. If word-of-mouth affects attribution of credit or blame for a purchase outcome, it could have important implications for post-purchase evaluations, satisfaction, word-of-mouth, and repurchase intentions (Swanson \& Kelley, 2001; Grewal et al., 2008). Therefore, the influence of an outside recommender, whether it is a known or unknown source, on the attribution of a purchase outcome warrants further examination.

\section{Word of Mouth}

Today, we understand "word of mouth" to be a unique contrast to the spread of information through media (one source, mass receivers). One person can spread a message or share their thoughts or opinions to one person or several people. The message can then spread over time as they tell more people, or as that audience shares what they have heard with others. Traditionally it is a slower communication channel centered on personal relationships. Building on the work of Whyte (1954), who first conceptualized WOM, Katz and Lazarsfeld (1965) stressed the idea that in many common situations, exposure to others can be more influential than exposure to the media using their two-step flow of communication model. Their study was intended to demonstrate the influence the media has in consumer decision making. Instead, they found that people are far more influenced by interpersonal communication with those closer to use (ie. friends, family, coworkers etc). This is still relevant today as we 
frequently seek the opinions, or are the receivers of information from those around us.

In 1966, Dichter published a study identifying product involvement, self enhancement, other involvement and message involvement as the four key motivations for engaging in WOM in the Harvard Business Review. One of these motivations, other involvement (or using WOM to interact with others), was highlighted by the well-known Bass-model (1969), which demonstrated that every consumer is connected to every other consumer. This connection allows consumers to have access to a variety of information and information sources. Due to this connection with others, the WOM literature began to focus on the diffusion process.

Research on the diffusion of WOM notes how quickly information can spread and identifies the drivers that allow WOM to disseminate quickly (Barnett, 1953; Rogers, 1962; Arndt, 1967; Bass, 1969; Sheth, 1971 Brown, 1981; Norton and Bass, 1987; Mahajan, Muller, and Wind 2000). Researchers have found that WOM is able to spread quickly due to the personal influence people have over others in their decision-making (Katz \& Lazarsfeld, 1965). Typically, we are most influenced by those we find credible or knowledgeable and are therefore more likely to gather opinions from those sources (Haywood, 1989). As a result, we have come to rely on our social network for information on any and all topics relevant to us.

The potential power of influence made opinion leaders of interest for much of the early research on WOM (Katz \& Lazarsfeld, 1965; Arndt, 1967). Feick and Price (1987) suggested that some of those disseminating information about products were doing so based on their knowledge and prior expertise or involvement in the product. These opinion leaders were referred to as 'market mavens' (Feick \& Price, 1987). 
Their information went beyond that of the traditional opinion leader in that information was not only about a product but also about the marketplace as they shared information about prices, best places to make purchases and couponing. These influencers, if they were identified, could play a critical role in promoting a particular product or service (for a review of WOM and its drivers see Berger, 2014). Therefore, market mavens became a key part of the WOM process, as they are not only trusted for general market information, but they are essential for learning in-depth information in regards to important shopping decisions.

While the influence of others is a key factor in the dissemination of WOM, another key factor for information sharing is valence. Beginning with Arndt's 1967 study of the effects of positive WOM (PWOM) and negative WOM (NWOM), communication valence has become a very important and complicated focus for WOM researchers. Arndt (1967) concluded that PWOM is more frequent compared with NWOM, and consumers are eight times more likely to receive favorable WOM than unfavorable WOM. More recently, East, Hammond, and Lomax (2008) found that consumers were only three times more likely to receive PWOM than NWOM across several categories. In addition to reception likelihood, there has been some debate in the literature over which type of WOM is more impactful. East et al. (20008) found that generally PWOM has more of an impact than NWOM, whereas others have claimed that NWOM can be more influential than PWOM (Bayus 1985).

Following in the footsteps of Engel, Kegerreis \& Blackwell (1969), who advised businesses that 'your best salesman is a satisfied customer', Breazeale (2008) concluded that NWOM has a more powerful influence on consumers due to the fact 
that dissatisfied customers disseminate their experience and feelings more frequently than those who are satisfied. While generally we do see those who are dissatisfied, quickly and loudly share their experience, consumers know that some people are difficult or hard to please. Today, most consumers look for a well-rounded view of a company or product, or seek advice from multiple sources in order to balance the positive or negative information. Despite the mixed results in the literature, East and others have found that both positive and negative WOM have a definite effect on purchasing behavior. Consequently, whether a consumer is sharing a positive or negative outcome, it is important for retailers to consider the influence this is having on other consumers.

A great deal of research has demonstrated that word of mouth affects choice, diffusion, and sales. Consumers are more likely to buy DVDs their friends recommend (Leskovec, Adamic, \& Huberman, 2007), and doctors are more likely to prescribe prescription drugs that other doctors whom they know have prescribed previously (Iyengar, Van den Bulte, \& Valente, 2011). This demonstrates what researchers have found for many years: that others have significant influence on our decision making. This is important, as the typical shopping process is primarily concerned with the consumer-retailer interaction. Recognizing that a third party can influence the purchasing process may have significant impact on who receives credit or blame for a positive or negative purchasing outcome.

\section{The Internet}

There is no doubt that the Internet has changed how we function. Our face-toface communication continues to move online, resulting in an unprecedented amount 
of consumer-generated information that impacts all aspects of decision-making, including those surrounding the purchase and use of goods and services (Goldsmith and Horowitz 2006). The online option has become the vehicle of choice for many to exchange opinions and share information (Hennig-Thurau, Gwinner, Walsh \& Gremler, 2004; Gruen, Osmonbekov \& Czaplewski, 2006; Brown, Broderick \& Lee, 2007; Edwards, Fisher, Jonach \& Manowitz, 2010). The internet has provided a space for consumers whether they are complete strangers or share an offline relationship, to connect with one another. This has given rise to what is commonly referred to as social media. Mirriam-Webster defines social media as "forms of electronic communication (such as websites for social networking and microblogging) through which users create online communities to share information, ideas, personal messages, and other content (such as videos)."

Today, social media is revolutionizing how businesses relate to consumers, who have the potential to connect with each other in new and powerful ways (Rayport \& Sviokla, 1994). The importance of this is highlighted by Armstrong and Hagel $(1995,1996$, p. 86) who proposed that 'commercial success in the online arena will belong to those businesses that organize electronic communities to meet multiple social and commercial needs.'

As early as 1995 , researchers recognized the importance of online conversations for businesses to build customer loyalty, competitive advantage and increase market share (see especially Armstrong \& Hagel, 1995). Several studies have emphasized the role of the Internet in building brands (Breakenridge, 2001) and managing customer relationships (Osenton, 2002). It has been suggested that 
businesses adopt new models to understand consumers who are actively involved online (Wind, Mahajan, \& Gunther, 2002). This means that companies should not be utilizing their previous internet strategies of mainly having a presence (whether that be through a website or blog) and instead focus on making connections between consumers. This can be done by creating brand communities, creating experiences for consumers who visit your site or who follow you on Facebook or Twitter (ie. Contests and giveaways), and generally creating more retailer-consumer and consumerconsumer interactions.

The social commerce handbook (Marsden \& Chaney, 2013) suggests 20 secrets for turning social media into social sales, including the allowance of reviews, interaction between shoppers, and an increase in shopping information that will allow consumers to make better purchasing decisions. This would provide consumers with the ability to make more informed decisions, which in turn should lead to more successful purchase outcomes. As a result of the influx of consumer shopping, searching and discussion online, marketers are aware that online word of mouth (electronic word-of-mouth [eWOM]) can - and will - impact sales, reputations, and brands. Therefore, it is essential for retailers to focus on eWOM and its impact on purchasing outcomes.

\section{EWOM}

Electronic word of mouth (eWOM) is defined as "any positive or negative statement made by potential, actual, or former customers about a product or company, which is made available to a multitude of people and institutions via the Internet" (Hennig-Thurau et al. 2004). Researchers have investigated numerous 
issues pertaining to both WOM and now its electronic partner eWOM. From why people share, to what they share, to how this impacts purchases, and how businesses can capitalize on this, researchers have made considerable contributions to the literature, and offered practitioners immediate solutions to their online problems. Written online communications between consumers (also consumer-consumer interactions by Yadav \& Pavlou [2014]) have emerged to play an important role in the consumer decision-making process (Cheung \& Lee, 2012). The Internet offers expansive options for communications; eWOM is available through new communication opportunities including blogs, social networking sites (Twitter, Facebook etc.), discussion/bulletin boards, and review sites (Goldsmith, 2006). A growing number of consumers trust online communications more than traditional media communications (Bickart \& Schindler, 2001; Goldsmith \& Horowitz, 2006). Based on this, more companies are now hiring staff, creating departments and increasing budgets in order to manage the eWOM process (Moorman, 2014). Hence, there is evidence that companies care about the eWOM and factors that can impact the outcomes related to eWOM.

This increased participation in eWOM has led to a variety of studies on its impact and diffusion (for a review on eWOM see King et al., 2014). We know that diffusion is impacted by not only what we share but also where or how we share it (Berger \& Iyengar, 2013). For example, Floyd and his colleagues (2014) presented a meta-analysis demonstrating the significant impact online reviews have on sales. You, Vadakkepatt and Joshi (2015) looked at eWOM, on blogs, forums, and social networking sites finding it significantly impacted sales. The main commonality in this 
research is the definite relationship between eWOM and sales. This means that, just as WOM impacted offline purchasing situations, online, the influence of other consumers is of great importance to the purchasing process. Therefore, retailers should utilize the power of eWOM to assist consumers in making purchasing decisions.

Online reviews are a form of eWOM that has been gaining more attention in the literature as of late (for a review see Trenz \& Berger, 2013). Online review research has investigated the effect reviews have on purchasing decisions (Park \& Lee, 2009; Zhu \& Zhang, 2010; Blazevic, Hammedi, Garnefeld, Rust, Keiningham, Andreassen \& Carl, 2013); a website's content effectiveness (Schlosser 2011, Ludwig De Ruyter, Friedman, Brüggen, Wetzels, Pfann, 2013); and the impact of positive and negative reviews on product evaluations (Sen and Lerman 2007, Chen \& Lurie, 2013).

These last two studies focused specifically on situations when positive and negative reviews may be more or less impactful. Sen and Lerman (2007) found that readers exhibit a negativity bias for utilitarian products, however when reading reviews of hedonic products, readers are more likely to attribute a negative review to the reviewer and not the retailer. This is important because it demonstrates the motivational factors consumers consider when reading reviews from others. Logically, hedonistic products are purchased for enjoyment and expectations may greatly differ person to person. Similarly, Chen and Lurie (2013) found that the timing of the review reduced attribution to the reviewer. Essentially, if a review is written immediately following the purchasing experience, it is more likely to be trusted and assumed accurate. These studies present unique situations where a third party's opinion is evaluated as part of the purchasing process. This is important, as 
online shopping continues to become more social.

Most online review studies have investigated various aspects of the online review itself, including the length, linguistics and valence (Wu, 2013; Floh, Koller \& Zauner, 2013; Chen \& Lurie, 2013; Packard \& Berger, 2015; Koo, 2015). These studies generally find that reviews that are too short, overly general or overly negative or positive are less helpful. Consumers look for reviews with details, that show pros and cons and are generally informative. Other studies have focused on what makes a review more trustworthy, credible or persuasive (Xu, 2014; Kusumasondjaja, Shanka \& Marchegiani, 2012; Pentina et al., 2015).

$\mathrm{Xu}$ found that both a reviewer profile picture and reviewer reputation information (i.e. reviewer rating) influenced a consumers trust, reviewer reputation was more influential overall. Kusumasondjaja, Shanka and Marchegiani found that when a reviewer is identified, a negative review is deemed more credible, but a positive review leads to greater initial trust. This difference disappears when the reviewer is not identified. Petina and collegues also discovered differences in relation to valence, finding that positive reviews (on Yelp) were seen as more trustworthy, credible and helpful when compared to negative reviews. Yelp also allows users to see reviewer information and ratings, therefore both studies demonstrate higher trust when readers have some information about the reviewer. Lastly, researchers have focused on the impact a review has on the reviewer and the reader of the reviews, highlighting that reviewers write reviews in order to help others, to enhance their reputation, and to relieve/reduce stress (Picazo-Vela et al., 2010; De Angelis, Bonezzi, Peluso, Rucker \& Costabile, 2011; King et al., 2014). These drivers are important, as 
retailers begin to utilize online reviews it is necessary to understand why people are driven to write reviews.

One area of online reviews that has been less explored is attribution of purchase outcomes. Understanding how the content that online users share will impact the attribution of a purchase outcome is vitally important because the existence of reviewers provides consumers with a third party with which to give credit or blame to. This means reviews could get some credit for a positive outcome, or blame for a negative one. More online retailers are adding reviews to their websites without knowing if these reviews will increase the likelihood that a successful purchase will be attributed to the retailer, or if they will help minimize the damage of a negative purchasing experience, as opposed to multiplying the impact of a failure. Therefore, this dissertation studies several components which may impact the attribution of credit or blame for a purchase, including: social identity, retailer identification and incentivization.

\section{Social Identity Theory}

Social identity is relevant in the context of product recommendations because consumption is one of the most significant ways we form and convey our identity. The image that we project demonstrates our belonging to specific social categories (Tajfel, 1978). Our social identities are composed of the attitudes, beliefs, and actions of these social categories (Kleine, Kleine, \& Kernan, 1993; Burke \& Stets, 2009). Individuals use their social identities to signal self-categorization and behavioral guidance (Markus \& Wurf, 1987), as well as self-verification (Swann, 1983) through

processes of regulating actions in order to appear in accordance with acceptable social 
standards (Oyserman, 2009; Reed, Forehand, Puntoni, \& Warlop, 2012). Essentially, our membership in a group (like a circle of friends) significantly impacts our behavior, attitudes and beliefs, shaping our idea of "self." In order to best assimilate, many times people will mirror the behaviors of those around them whom they find represent their ideal identity (Asch, 1955; Bearden, Netemeyer, \& Teel, 1989; Burnkrant \& Cousineau, 1975; Sherif, 1936). This is not limited to those in our social circle, but also prominent or influential individuals or groups that represent the beliefs of our aspirational identity (Berger \& Heath, 2007, 2008; Escalas \& Bettman, 2003, 2005). This means that we will buy things based on what those in our social circle will buy, or what our favorite celebrity or influencer would have. Sometimes we will even avoid buying things because we see others have them, commonly referred to as "bucking the trend" (think ponchos, kale, or fidget spinners). Therefore, the influence these people have over daily consumption experiences is significant.

Typically, we are friends with those that we feel we share similarities with. Many studies have looked at students sharing common spaces, classes, or characteristics and found these similarities to be important drivers for friendship (Mehra, Kilduff \& Brass, 1998; Frank, Muller \& Mueller, 2013; Easterbrook \& Vignoles, 2015). From a young age friends influence our involvement and participation (Berndt \& Keefe, 1995). Friendship plays a special role in our lives when we are searching for our identity (ex. teens or retirees) (Misztal, 2013). Friends enhance our self-esteem and contribute to our evaluation of self by accepting us and showing us they value our thoughts, beliefs and friendship (Misztal, 2013). A study by Siebert and colleagues (1999) found friendship identity meanings to be the 
strongest predictor of life satisfaction. This can be seen in our daily lives as we rely on our friends, whether it be for communication through phone calls and texts, sharing in enjoyable activities or helping with anything from moving to child care. This means that friends function as a trusted resource, and as a result greatly influence our consumption behavior.

Past literature has indicated that a message supplied by someone who is seen as similar to the receiver, like a friend, is more influential than a message from someone dissimilar (Simons et al., 1970; Woodside \& Davenport, 1974). Feick and Higie (1992) support the idea that similar communicators are perceived as being more influential than dissimilar ones. Burger, Messian, Patel, del Prado, \& Anderson (2004) found that people are more likely to agree to something when asked by someone who shared an incidental similarity with themselves. Source similarity or homophily is the degree to which individuals are similar in relation to specific attributes (Brown \& Reingen, 1987), and friends frequently share more similarities with us than acquaintances. This means that we are more likely to trust and be influenced by those who we share similarities with, highlighting how influential friends and family can be.

Many researchers have identified the significance of source similarity to the communication process. The source-attractiveness model and the theory of social comparison suggest that receivers can best identify with senders who are seen as similar to themselves, and similar people are thought to have similar needs and wants (Kelman, 1961; Festinger, 1954). Having similar needs and wants typically leads to engaging in mutually pleasurable activities that enhance one's sense of self (Werner \& Parmelee, 1979). This is frequently how circles of friendship develop. People who 
enjoy engaging in similar activities and have overlapping interests and commonalities share time, information and conversation, becoming a social circle. This means that friendship is an important bond, not only influencing us but also assisting in our identity formation.

The operationalization of "friend" is less clear. The social identity literature mainly considers social identity to be a unidimensional construct, concentrating on group affiliation or belongingness (Jetten, Spears \& Manstead, 1996). However social identity theory as defined by Tajfel (1978) should allow for 3 components: Cognitivebeing aware of membership in a social group, Evaluative- feeling positively or negatively towards being attached to this group, and Emotional- being emotionally involved in the group (Ellemers \& Mlicki, 1996). This makes sense as friendship can come in many forms. Many of us have what we might consider "best friends" who we may be significantly more close to than say a friend at work, whom we may spend time with socially, but wouldn't for example count on in an emergency. This variation in the meaning of friend is relevant for the current studies operationalization as it is hard to define the type of relationship (very close vs more casual), as well as what is at the core of the relationship (bonded through work, sports, schooling, family etc.).

The literature typically operationalizes the relationships with friends or strangers using strong and weak ties. This concept of relationship closeness, termed "tie strength" was first introduced by Mark Granovetter in his 1973 paper "The Strength of Weak Ties" (Granovetter, 1973). The core of his concept was the differentiation between two types of relationships which he characterized as "strong" and "weak" ties. Strong ties are typically people who you trust most, have frequent 
contact with and many commonalities. In contrast, weak ties are typically acquaintances with whom we have less contact or overlapping interests. This means that typically strong tie relationships would be with those we trust more and who have a greater impact on our identity. Thus, these relationships should be the most significant in terms of influence in a consumption setting.

Measuring these relationships has proved difficult in the literature. Granovetter suggested four predictors of tie strength: amount of time, emotional intensity, intimacy and reciprocal services. Subsequent research has gone on to highlight other factors such as informal social circles and network topology (Burt, 1995), emotional support (Wellman \& Wortley, 1990), and social distance (differences in political views, socioeconomic status, education levels, age, race and gender (Lin, Ensel \& Vaughn, 1981). Other researchers have focused on communication (reciprocity, recency and frequency) as well as shared friends (Friedkin, 1980; Shi, Adamic, \& Strauss, 2007; Lin, Dayton \& Greenwald, 1978). Both Marsden and Campbell $(1984,1990)$ and Gilbert and Karahalios (2009) found emotional closeness best represented tie strength. This disparity in the key factors that predict tie strength has made operationalizing social identity difficult.

Many researchers, including Marsden and Campbell (1984, 1990), point out that measuring relationship closeness requires participant recollection and description of a relationship. This description may not always be accurate. Gilbert and Karahalios (2009) utilized both participant interviews and Facebook data and yet still found that not all key factors could accurately predict tie strength due to unique relationship factors that can be difficult to understand. For instance, someone may 
feel emotionally close to an ex whom they do not communicate or interact with frequently, or a coworker who differs from them in race, age, political views and education level.

To complicate things further, even if tie strength can be accurately predicted, individuals utilize social networks differently depending on their needs. For instance, individuals may seek more emotional support from those closest to them, but may reach out to weaker ties when job hunting or requesting information from a wider array of individuals. In this example, weaker ties may have less in common with you and your inner network and therefore would have more contacts, ideas and information that do not overlap with your own. This means that while strong ties are more trusted and can be more influential, depending on the topic, this may not always be the case. For example, you may have a weaker tie friend who is a sports expert who you would more readily consult with on current sports topics, than a close tie friend who is not aware of most sporting news. This means that strong ties may not always be the most influential in a purchasing context. Therefore, it is not enough to consider only a strong tie relationship or a weak tie relationship but also the type of information gained from these relationships.

This decision (using strong ties or weak ties) can depend on the number of ties one has at various tie strength levels and also the utility of different strength ties (Pool, 1980). This means that though someone may generally find weak ties to be more helpful, they may not be able to utilize them if they do not have a lot of weak tie relationships in their social circle. Thus, measuring relationship closeness is difficult 
due to both the aforementioned challenges in measuring tie strength and understanding what type of source a person would use when making a purchase.

While we commonly think of friends or family as people we share similarities with and form relationships with, in marketing it is important to also consider relationships with retailers. As consumers, we are able to form relationships with retailers the same way we do with people in our everyday lives.

\section{Retailer Identification}

In the marketing context, consumers identify and associate themselves with brands that reflect and reinforce their self-identities (Bhattacharya \& Sen, 2003). Consumer-brand identification in this context refers to the individual's overall sense or feeling of sameness with a particular brand (Tuskej, Golob \& Podnar, 2011). Previous research conceptualizes consumer identification with a retailer as an active, intentional action, motivated by the desire to fulfill personal identity related needs (Dutton, Dukerich \& Harquail, 1994; Pratt, 1998). Kim et al. (2001) define the level of consumer-brand identification as "the degree to which the brand expresses and enhances a consumers' identity."

Researchers agree that brands are important in creating and communicating consumer identity (Kuenzel \& Vaux Halliday, 2008; Rodhain, 2006). Even though the consumer-brand relationship is not interpersonal, the relationship marketing literature has shown that we find similar values such as trust, commitment and love as important for our relationships with brands as it is for personal relationships (Palmatier, Dant, Grewal \& Evans, 2006; Ortiz \& Harrison, 2011). In this circumstance the brand fills the role of "other" that the consumer identifies with and consumers are able to 
humanize the brand (Fournier, 1998). Consumers tend to create powerful relationships with brands because they express and enhance one's identity, and can be included in their identity formation as an extension of self (McEwen, 2005; Belk 1988). Consumers are more likely to consider a brand's identity attractive when the brand's identity matches their own sense of who they are because this allows the consumption of the brands products to more realistically represent their ideal sense of self (Bhattacharya \& Sen, 2003).

Brands can positively benefit from and utilize consumer identification. Consumers who identify with a brand will be more fully committed and loyal to the brand, are more likely to repurchase from them, and generate more positive WOM (Tuskej, Golob \& Podnar, 2011; Kim, Han \& Park, 2001; Kuenzel \& Vaux Halliday, 2008). Hong and Yang (2009) found that identification mediates the influence of organizational reputation on positive WOM. Keh and Xie (2009) found that identification influences commitment and willingness to pay a price premium.

Companies have utilized the benefits of brand communities (ie. Jeep Clubs or TJMaxx's Maxxinista's) to capitalize on consumer identification. Brand communities reinforce a connection from each consumer to the brand and also to each other (Muniz \& O'Guinn, 2001). Consumers can also seek identification even when they are not actual members of a particular group: 'To the extent that the group category is psychologically accepted as part of the self, an individual is said to be identified with the group' (Scott \& Lane, 2000, p.46). This means that groups can significantly impact a consumers purchasing habits, whether they are actually in the group, or just identify with it. Therefore, having brand communities will increase the likelihood that 
consumers may aspire to become a member and emulate their purchasing habits.

\section{Incentives}

Loyal customers are important for a retailer, especially as they look for consumers to write online reviews. While online reviews do lead to an increase in sales, many people do not write reviews. While many consumers participate in the consumption process many times over days, months and weeks, they frequently do not write a review for these experiences. Thus, what can companies do to encourage more reviews?

Several studies have looked at the impact incentivization has on consumers writing reviews. Petrescu, O’Leary, Goldring and Mrad (2017) found that incentivizing reviewers on Amazon led to an increase in the number of reviews not only during the incentivization campaign but also after. This is important because it demonstrates the ability to motivate consumers long-term which is always preferable and cost effective when it leads to sales. Tercia and Teichert (2017) found that while incentives may get consumers to write more reviews, it does not necessarily mean they will write the reviews the retailer wants. They found that men were actually less likely to write a review that was in line with retailer intentions, where-as women were more likely to comply with behavioral norms. The relationship between incentives and reviews raises questions about how incentives affect attributions of review outcomes.

There are also privacy concerns related to incentivized reviews. In 2009, the FTC updated its policies in regards to online messages shared on behalf of a retailer including incentivized reviews (FTC, 2009). Users are now required to disclose that 
they received an incentive for writing the review. This means that consumers now see that reviewers were given an incentive and may now feel like these reviews are biased or misleading. This is demonstrated in a recent study by Martin (2016) that found that when consumers are aware the reviewer was incentivized, the reviewer is found to be less trustworthy. This is important because if we want consumers to trust positive reviews, the consumer must trust the reviewer. Thus, retailers need to be very careful when implementing incentive-based review strategies. An understanding of how incentivized reviews affect consumer attributions of product performance outcomes can help inform these strategies. 


\section{CHAPTER 3}

\section{HYPOTHESES DEVELOPMENT AND MODEL}

\section{Social Identity and Attribution of Causality}

Existing literature shows evidence of retailer attribution for purchases (Curren \& Folkes, 1987; Landon \& Emery, 1975; Valle \& Wallendorf, 1977; Curren \& Folkes, 1987; Richins, 1983; Tsiros, Mittal \& Ross, 2004). However, when we are influenced by a source outside of the retailer, who is likely to receive the credit or blame for a purchase outcome?

Traditionally, we trust friends and have no obvious allegiance to strangers. Friends are a part of our identities (Prelinger, 1959). When a friend does something right, it is likely to reflect positively on oneself (Maxwell \& Dornan, 1997). Therefore, when we receive recommendations from friends, if the end result of the product experience is positive, we would give credit to our friends. However, if the outcome is negative we tend to give them the benefit of the doubt, and in the case of a consumption activity, we place the blame on the retailer. A 2014 study on negative WOM attribution (Ebeid \& Gadelrab, 2014) found that on average, people attribute the negativity of WOM to brands more than their attribution to the communicator. They argued that this was likely due to the trust and credible nature of an offline WOM source. This study seeks to see if this occurs when reading reviews from strangers in an online environment. Do they receive the blame for an unsuccessful purchase, and/or lessen the blame to the retailer? 
There is also evidence of a self-serving, internal attribution for positive events that contrasts with an external attribution for negative events (e.g. Campbell \& Sedikides, 1999; Moon, 2003). The research suggests that in order to protect one's self-esteem or protect one's ego, consumers may take credit for successful purchase outcomes, while attributing negative purchase outcomes to the retailer (Moon, 2003). Research has not focused on the influence of a third party, a reviewer, on the attribution of a purchase outcome. The first three hypotheses aim to address this gap in the literature as it investigates the influence of an outside recommender, whether it be an offline (known) source or an online (unknown) external source, on the attribution of a purchase outcome.

The way consumers attribute causality for product outcomes is important because people engage in consumption behavior, in part, to construct their selfconcepts and to create their personal identity (e.g., Belk, 1988; Richins, 1994; Escalas $\&$ Bettman, 2005). This process begins at an early age with the help of parents, family members, friends, schooling and the media (Chaplin \& Lowrey, 2010; Littlefield \& Ozanne, 2011; Kratzer \& Lettl, 2009; Richins \& Chaplin, 2015). Belk’s (1988) seminal article noted that consumers use items or objects to expand on their core selves. These items become part of the extended self, and can be used to satisfy psychological needs, such as reinforcing and expressing self-identity, and allowing one to differentiate oneself and assert one's individuality (e.g., Ball \& Tasaki, 1992; Belk, 1988; Kleine, Kleine, \& Allen, 1995).

Possessions can also serve a social purpose by reflecting social ties to one's family, community, and/or cultural groups, including brand communities (Muniz \& 
O'Guinn, 2001; Escalas \& Bettman, 2005; Algesheimer, Dholakia \& Herrmann, 2005). Products can signal our status (Wang \& Griskevicius, 2014), our individuality (Quester \& Steyer, 2010; White, Simpson, \& Argo, 2014), or our relationships (Fuchs, Schreier, \& van Osselaer, 2015). Therefore, a self-serving bias influences how consumers assign credit or blame for product outcomes, since the outcomes relate to their identities.

A consumer's extended self is not only created through the purchase of products. Another key component in our identity formation are the relationships we form (McClelland, 1951; Prelinger, 1959; Belk, 1988). Friends, family and acquaintances all impact our daily lives and serve as important influencers of our selfperception. Other people are both fundamental to the self and also potentially used as possessions that form part of our extended self (Goldner, 1982; Belk, 2013). Aron, Aron, Tudor, and Nelson (1991) even found that the love we have for others involves a fusing of identities, leading to one's sense of self growing to include the loved other.

As we expect our relationships to be a reflection of us, we would expect friends to behave in our best interest. We try to make good decisions and behave in a way that positively influences those around us, and we anticipate that our friends will model similar behavior. This is a logical extension, because similarities are often the cornerstone of a friendship (Simpkins, Parke, Flyr, \& Wild, 2006). Based on this, when making a purchase due to the recommendation of a friend, purchase attribution should be directed towards the friend. If we are satisfied with our purchase based on their recommendation, satisfaction will be attributed to the friend, not the retailer.

H1: When a review is made offline (WOM), attribution to the reviewer is more likely when post purchase outcome is positive rather than negative. 
If we believe there is a concern for us from the other person, we are less likely to blame them for an outcome that seems inconsistent with this view (Kollock, 1994). If the outcome is negative, we are less likely to believe our friend intentionally directed us toward an unsatisfactory product and are quick to forgive them (McCullough \& Witvliet, 2002). Further, protecting the friend, who can be part of the extended self, from blame is also a way of protecting oneself from blame. Therefore, if we are unhappy with our purchase, this dissatisfaction will be attributed to the retailer, not the friend making the recommendation.

H2: When a review is made offline (WOM), attribution to the retailer is more likely when post purchase outcome is negative rather than positive.

The Internet enables WOM to be more powerful than ever before, offering more opportunities for both businesses and consumers due to the extensive reach of the message. Online reviews now provide the consumer with the opportunity to experience eWOM by receiving information shared by a complete stranger from anywhere in the world.

Several studies have shown that consumers are using reviews for decision making, and that factors such as valence and length of the review, similarities between the reviewer and reader (characteristics, linguistic styles) and product characteristics all play a role in whether or not a consumer will make a purchase based on a review (Chevalier \& Mayzlin, 2006; Zhu \& Zhang, 2010; Zhang, Craciun \& Shin, 2010; Ludwig, De Ruyter, Friedman, Brüggen, Wetzels, \& Pfann, 2013). Senecala and Nantel (2004) found that consumers who consulted product recommendations were twice as likely to buy the product than those who did not consult recommendations. Based on findings from Cisco (Fretwell et al., 2013), it appears that online consumers 
are willing to trust online reviews when making a purchase, despite the anonymous and distant nature of reviewers.

While they may be willing to trust an online reviewer's recommendation, they do not have a close personal relationship with the recommender. Social Media Sites (SMS) allow users to interact with others in their social circle (or desired social circle) (Correa, Hinsley, \& De Zuniga, 2010). A well designed narrative of who you are and who you prefer to interact with is easily created using pictures, posts, likes and follows (Ellison, 2007; Livingstone, 2008; Lata \& Singh; 2016). Popular retailer websites do not allow users to utilize this network in order to make purchases. Therefore, purchasing decisions must be made without the knowledge of how those who have played a role in shaping your social identity feel about the purchase.

When considering the relationship a consumer has with the brand itself, some important distinctions exist. The feelings a consumer has for the brand exist both on and offline (as it would in a personal relationship). Fournier (1998) described a strong relationship as containing "affective and socioemotive attachments (love/passion and self-connection), behavioral ties (interdependence and commitment), and supportive cognitive beliefs (intimacy and brand partner quality) (Fournier, 1998). This brand relationship can function similar to a traditional relationship between two individuals. If you purchase a product, the purchase is attributed to the retailer, with whom you can form a relationship with more easily than a reviewer. Specifically, when you make a purchase and your purchase was satisfactory, due to the lack of relationship formed with the online reviewer who recommended the product, consumers will attribute their satisfaction to the retailer. 
H3: When a review is made online (eWOM), attribution to the retailer is more likely when post purchase outcome is positive rather than negative.

Wan, Hui and Wyer (2011) found that relationship closeness attenuated the effect of service failures. When there is a closer relationship between the consumer and retailer (service provider) and the outcome is negative, the consumer is inclined to give the retailer the benefit of the doubt, as they do for their friends WOM recommendation. When dealing with the brand or organization specifically, the company is more empowered to take responsibility and to correct any mistakes that were made. Nyquist, Bitner, and Booms (1985) found that even service delivery system failures can be remembered as highly satisfactory encounters if they are handled properly.

In contrast, online reviews come from strangers. The "benefit of the doubt" or ability to right a wrong, is not available for someone when no relationship exists. As the reviewer(s) would be the only contact person in the situation, their influence on the consumer can be significant. A study of relationship marketing in the life insurance industry found clients' satisfaction with their contact person to be a significant predictor of overall satisfaction with the service (Crosby \& Stephens, 1987). More notably, studies have shown that when people feel they are victims, they have a tendency to hold other victims responsible as they should have already known and therefore prevented the injury to others (Celsi, Rose, \& Lee,1993; Folkes \& Kotsos, 1986). The reviewer provides another external party to which blame may be assigned and, unlike the retailer, the consumer did not choose the reviewer. Therefore, if a reviewer recommends an unsatisfactory product, they are the least protected in the 
consumer's defense of his/her own ego, and are likely receive more blame than a friend or the retailer.

H4: When a review is made online (eWOM), attribution to the reviewer is more likely when post purchase outcome is negative rather than positive. When consumers make a purchase and are satisfied or unsatisfied, they can also assign credit or blame internally, or to themselves, for the outcome (Moon, 2003). Literature on self-attribution first found a relationship between attributions and satisfaction over 30 years ago (Krishnan and Valle 1979; Valle and Wallendorf 1977; Folkes, 1984; Richins, 1985). These findings, in conjunction with those of Weiner, Russell, and Lerman (1978), suggest that when referring to product purchases, consumers are more likely to assign causality for satisfactory (vs. dissatisfactory) purchase outcomes to internal (vs. external) sources (Oliver \& DeSarbo, 1988).

The self-attribution literature also states that typically we consider whether or not the results of a purchase were in our control or that of external factors (Machleit \& Mantel, 2001). Generally, researchers have found a self-serving attribution bias to occur, where consumers are more likely to take responsibility for success and less likely to assume blame for a failure (Miller \& Ross, 1975; Arkin, Appelman \& Burger, 1980). This self-attribution bias is unlikely to be impacted by communications on or offline, as our willingness to shield ourselves from blame should not change. In addition, for the purposes of this study, the attribution to "self" should not change based on the consideration of a third party review. Therefore, the study aims to replicate two previously supported hypotheses:

H5: When a review is made offline (WOM), attribution to self is more likely when post purchase outcome is positive rather than negative. 
H6: When a review is made online (eWOM), attribution to self is more likely when post purchase outcome is positive rather than negative.

\section{Identification with the Retailer and Attribution of Causality}

The first study will test hypotheses 1-6, which investigate whether attributions of responsibility for a product outcome (credit or blame) shift depending on the nature of the product outcome (positive or negative) and the source of the review (offline or online). The hypotheses suggest credit or blame is assigned to external sources (an offline reviewer/friend, an online reviewer/stranger, the retailer) based on the sources' respective links to the consumer's identity. The second study will focus on negative product outcomes, and will examine whether the source of the online review (friend or stranger) and consumer identification with the retailer interact to affect consumer attribution of blame.

The social identity literature suggests that friends are more likely to gain credit for successful product outcomes and protection from blame via the same self-serving bias that affects internal attribution, since friendships can serve as an extension of the self (Belk, 1988). Einwiller and Kamins (2008) noted this protection, finding that those who identified with the target of a rumor were less likely to believe an aversive rumor. Consumer ties to specific social categories, including friendships, can result in the defense of attitudes, beliefs, and actions of others that belong to those social categories (Kleine, Kleine, \& Kernan, 1993; Burke \& Stets, 2009). Consumers regulate their actions to adhere with acceptable social standards from their friendship groups (Oyserman, 2009; Reed, Forehand, Puntoni, \& Warlop, 2012), and adopt the behaviors of those around them whom they find represent their ideal identity (Asch, 
1955; Bearden, Netemeyer, \& Teel, 1989; Burnkrant \& Cousineau, 1975; Sherif, 1936).

Another way friendship may influence the attribution of causality is the influence of the reviewer based on similarity to the consumer. Past literature has indicated that a message supplied by someone who is seen as similar to the receiver is more influential (Simons, Berkowitz, \& Moyer, 1970; Woodside \& Davenport, 1974; Feick \& Higie, 1992), even when the similarity seems irrelevant in the context of the communication (Burger, Messian, Patel, del Prado, \& Anderson, 2004). Therefore, an online review from a friend may trigger a self-serving bias, whereas an online review from a stranger does not.

While friends have been shown to significantly impact our identity formation, the relationship marketing literature has shown that consumers are able to form strong bonds with retailers (Berry, 1983; Blackston, 1992; Crosby, Evans, \& Cowles, 1990; Morgan \& Hunt, 1994). If a consumer identifies with a retailer, the retailer becomes an extension of the consumer. Therefore, consumers may feel more motivated to defend the retailer in the same way the consumers would defend themselves (Lisjak, Lee, \& Gardner, 2012; Dunn \& Dahl, 2012). In other words, when a consumer identifies with the retailer, the retailer is likely to be protected from blame following a negative purchase outcome because they trigger a self-serving bias.

There is mixed support for the idea that relationships with retailers protect them in the event of a negative purchase outcome (for a review on service recovery see Van Vaerenbergh and Oringher [2016]). Ahluwalia and her colleagues (2000) found evidence that commitment protected brands from negative information. 
Chaudhuri and Holbrook (2001) found that when a brands performance was below expectations, customers with stronger brand identification tend to be less dissatisfied. Bhattacharya and Sen (2003) found that those with stronger brand identification were more resilient to negative information and experiences involving the brand. There is also evidence that a consumer's relationship with the firm can impact the way consumers respond to purchase outcomes, as it makes consumers more tolerant of service failures (e.g. Evanschitzky, Brock, \& Blut, 2011).

On the other hand, Grégoire and Fisher (2008) found evidence that attributions of a firm's control over a service failure affected the likelihood of retaliation, and, in some instances, led to greater retaliation in response to negative purchase outcomes from consumers who were in relationships with the firm. Grégoire, Tripp and Legoux (2009) suggest that consumers in relationships with service providers are more likely to respond positively to service recovery efforts following a service failure than their less committed counterparts, even if recovery efforts are poor. However, in the absence of service recovery efforts, committed customers are more likely to hold onto a grudge following a service failure. Wan et al. (2011) found that when in a communal (friendship) relationship with a service provider, and a service failure is viewed as a clear violation, consumers react more negatively than consumers who are in an exchange relationship.

In the context of negative publicity, Einwiller and her colleagues (2006) found evidence that while identification with the firm protects the firm from moderately negative publicity, it did not protect the firm from extremely negative publicity. Schmalz and Orth (2012) found that consumer relationships protected brands from 
negative consumer judgements when they made moderate ethical missteps, but did not protect brands when the ethical missteps were extreme. Trump (2014) found that brand relationships did not protect firms when the brand transgression was ethical in nature or was personally relevant to the consumer.

To address this conflict in the literature in the context of attribution of blame, and to study how consumer relationships with retailers might interact with the source of a review to affect consumer attributions following a negative product outcome, hypotheses 7, 8 and 9 suggest that the consumer's relationship with the retailer can affect attribution of blame to reviewers and retailers. Specifically:

H7: When a favorable review is made online (eWOM) and the purchase outcome is negative, attribution of blame to the reviewer is greater when the reviewer is a stranger than when the reviewer is a friend.

H8: When a favorable review is made online (eWOM) and the purchase outcome is negative, attribution of blame to the retailer is greater when the reviewer is a friend than when the reviewer is a stranger.

H9: Identification with the retailer moderates the relationship between review source and attribution of blame to the retailer, such that identification with the retailer protects the retailer from blame.

\section{Incentivized Reviews}

Study three will extend the first two studies and examine what happens when a reviewer is compensated for the review. It focuses on reviews from strangers because the hypotheses from studies 1 and 2 suggest reviews from strangers may offer retailers more protection from blame than friends. 
One significant difficulty for retailers is actually getting consumers to write online reviews. More than half (55 percent) of all consumers and $69 \%$ of consumers making more than $\$ 150,000$ who are not writing reviews, lack the motivation to do so (PowerReviews, 2014). Research has shown that incentives can increase the rate of reviews (Pinch \& Kesler, 2011; Cabral \& Li, 2015). The quality is not always better (Wang, Xie, Liu, \& Yu, 2012), but increasing the incentive amount can increase the quality of the review (Pavlou \& Wang, 2015). Stephen, Bart, du Plessis, and Gonçalves (2012) found that these reviews can be seen as more helpful, but only when the incentive was not disclosed, which decreased perceptions the review was helpful. This is further complicated by the FTC mandating that retailers have to communicate if they have compensated someone for a review (FTC, 2009).

Do retailer incentives impact attribution of blame to the retailer following a negative product outcome? If the retailer that the consumer identifies with incentivized the positive review and the consumer has a negative product outcome, the consumer may assign blame to the retailer. Because the negative product outcome is personally relevant and might be seen as more of an ethical misstep, particularly if the consumer feels the retailer rigged the review process, identification with the retailer may not protect the retailer (Einwiller, et. al, 2006; Schmalz \& Orth, 2012; Trump, 2014). In fact, identification may increase the blame assigned to the retailer, particularly if the consumer feels betrayed (Grégoire \& Fisher, 2008). Study 3 tests whether:

H10: Incentives for consumer reviews increase attribution of blame to the retailer following a negative purchase outcome. 
H11: Identification with the retailer moderates the relationship between incentives and attribution of blame to the retailer, such that identification with the retailer increases the blame attributed to the retailer.

The following models demonstrate what has been previously looked at in the literature (Figure 1) and what this research is adding to that literature (Figure 2).

Figure 1. Existing Model
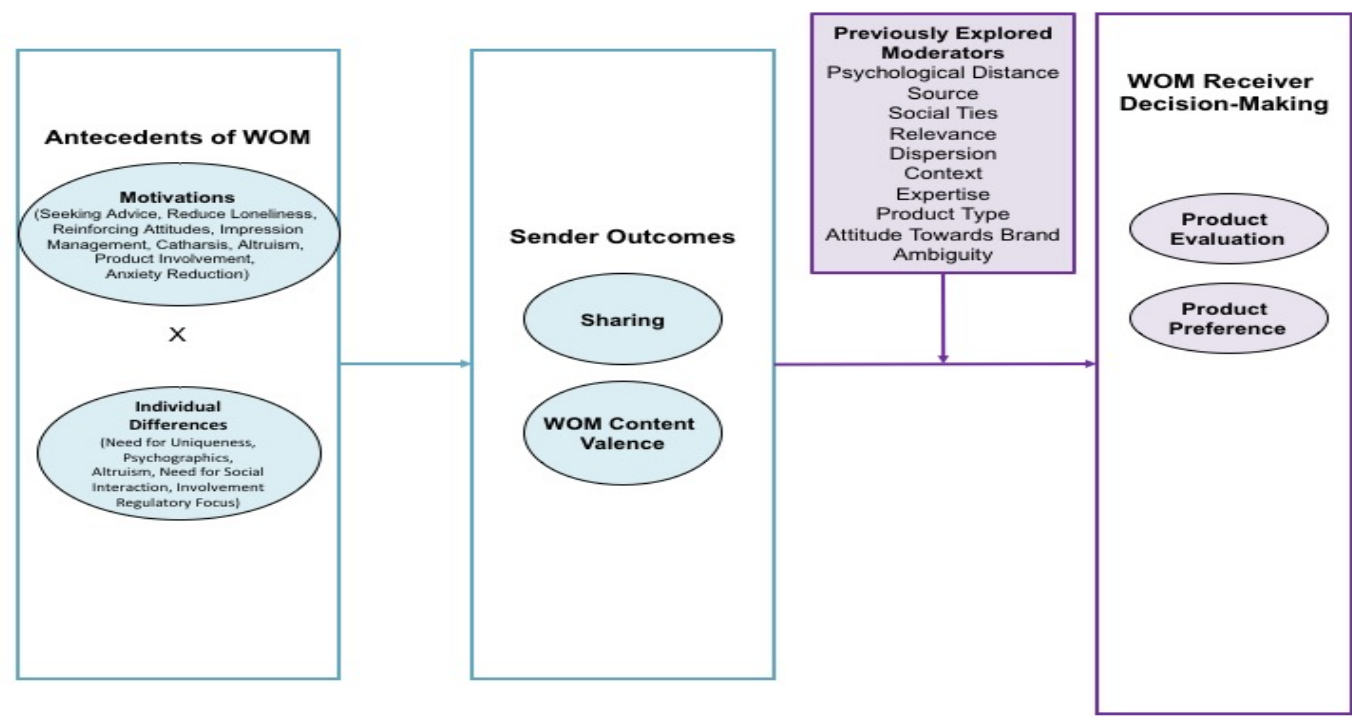

Figure 2. New Model
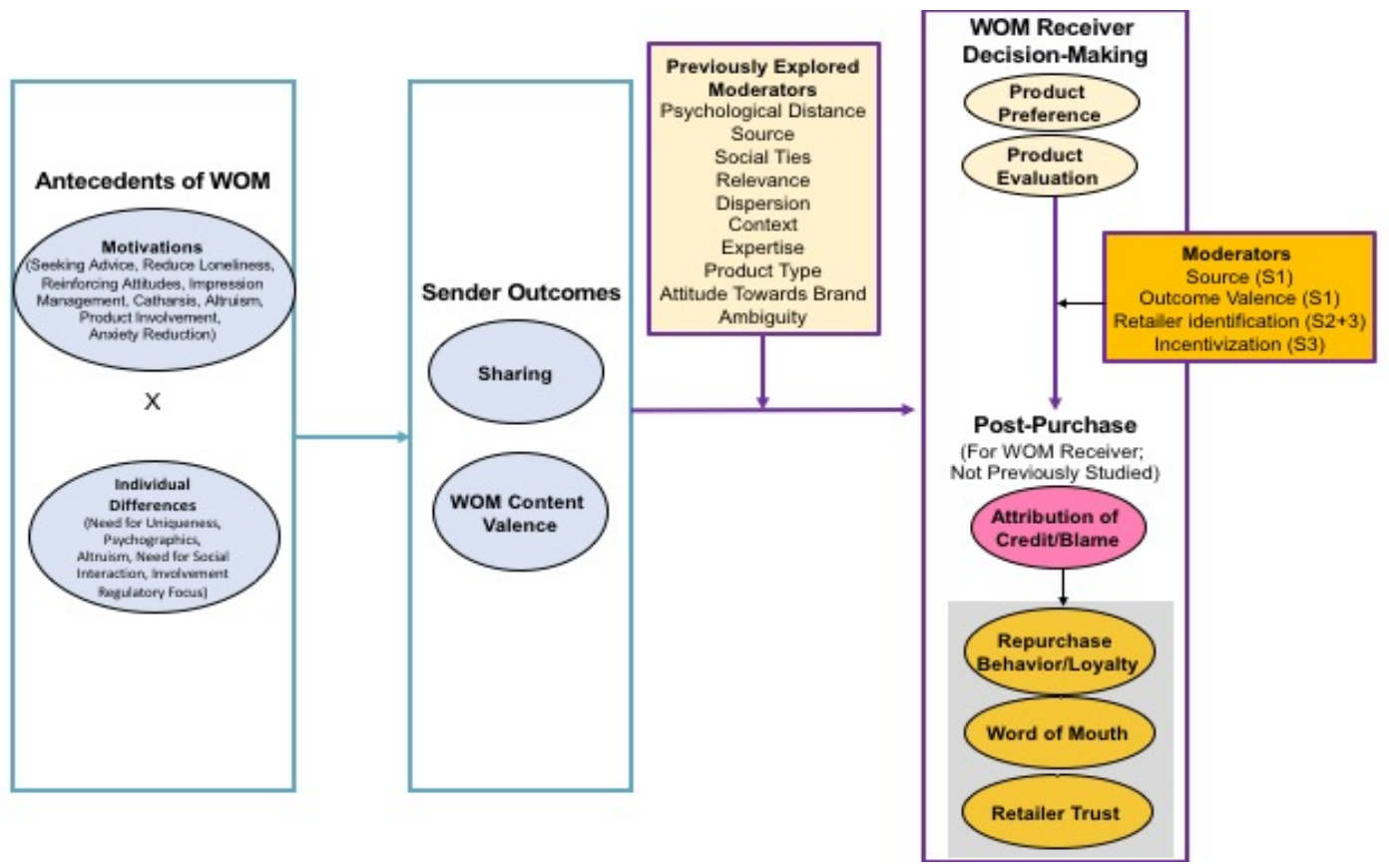


\title{
CHAPTER 4
}

\author{
STUDY ONE
}

\section{Overview}

The objective of study 1 is to measure whether review modality (online vs. offline) and the valence of the purchase outcome (positive vs. negative) change attribution of credit or blame for the purchase outcome to the retailer, reviewer, or consumer (H1-6). Study 1 consists of a 2 x 2 between-subjects full factorial experimental design. The first manipulation is whether the reviews are communicated online or offline (WOM vs. eWOM). The second manipulation is whether the purchase outcome was positive or negative. One hundred thirty-seven undergraduate students from a large North American university were randomly assigned to one of four conditions. All study participants voluntarily participated for course extra credit.

\section{Method}

\section{Procedure}

Participants were tested by completing an online survey. When they clicked the link, they read an informed consent document and agreed to participate in the study. Written scenarios were used to manipulate the variables, which have been employed in prior services research (e.g. Bitner, 1990; Voss, Parasuraman \& Grewal, 1998). The scenario either suggested the reviews were provided offline by three friends (WOM condition) or online by three reviewers (eWOM condition). Controlling for the nature of strong ties and weak ties in an experiment has proven 
difficult in previous literature that considers social identity, and the current study does not try to resolve the challenge. Instead, it allows participants to naturally consider the purchase without calling to mind specific close friends (who may or may not be helpful shopping companions).

Participants in the WOM conditions were asked to read the reviews associated with the scenario out loud to increase their engagement with the content and the realism (Westerman et al., 2013). To control for expectations, participants were asked how satisfied they expected to be with the product on a 1-5 scale with not at all satisfied to very satisfied as endpoints.

Then, a second part of the scenario explained that they were either satisfied (positive outcome) or dissatisfied (negative outcome) with the product. Participants in the positive (negative) outcome condition were instructed to assume they purchased the product from the online retailer and were satisfied (dissatisfied) with the purchase. They were either told they had a similar experience to their friends or the reviewers and found the t-shirt exceeded expectations, or they were told that despite their friends' or the reviewers' satisfaction, the t-shirt was below their expectations.

The purchase outcome portion of the scenario was pre-tested with 36 respondents from the same population. It showed participants in the positive outcome condition $(M=3.4)$ perceived satisfaction with their purchase to be higher than those in the negative condition $(\mathrm{M}=1.8 ; \mathrm{t}(36)=-17.23, p<.03)$. While $93 \%$ of pre-test participants in the positive outcome condition reported they would be likely to purchase from the online retailer in the future, $94 \%$ of pre-test participants in the negative outcome condition said they would be less likely to purchase from this 
retailer again. The scenarios are included in the Appendix.

\section{Dependent Variables}

The dependent variables of interest are the attribution of credit or blame for the product outcome to three different sources: Retailer, Reviewer, and Self. Participants were asked: "To what do you attribute your satisfaction (dissatisfaction) to?” and were asked to choose Reviewers/Friends, Retailer, or Self. Next, they were asked to rate how much they attributed their satisfaction (dissatisfaction) to the retailer, friends or reviewers, and self on a 0-6 scale with "not at all" and "completely" as endpoints.

\section{Additional Measures}

As a manipulation check, participants were asked: "Specifically, who recommended the product to you- friends, online reviewers or other?" One respondent was unable to correctly answer and was removed from the data set. The second manipulation check revealed that participants in the positive outcome condition $(\mathrm{M}=3.6$, on a 1-4 scale anchored by very unsatisfied and very satisfied) perceived satisfaction with their purchase to be higher than those in the negative outcome condition (M=1.9), and $90 \%$ of those in the positive outcome condition would be likely to purchase from this retailer in the future (compared to $93 \%$ of those in the negative outcome condition being less likely to purchase from this retailer again). Covariates included familiarity with online shopping, time spent online and technological skills. Each was evaluated and none was found to be significant ( $\mathrm{p}>.30)$, so they are not included in the analysis.

Participants were also asked "How much of an effect does your purchase satisfaction (dissatisfaction) have on your expectation to purchase from this retailer in 
the future?" with options of No effect, less likely and more likely to purchase again. Participants were asked how likely they would be to try another product that was recommended by these friends (reviewers on this retailers' website) on a 0-6 scale (not at all likely-very likely). Cognitive responses were included in order to better understand consumer processing. Participants were asked: "Why do you think your friends (the reviewers) highly recommended the product? (for the negative conditions the following was added: "and yet you were dissatisfied?").

\section{Results}

The sample consisted of 136 student participants (49\% female, aged 18-34). Participants indicated that they shop online fairly often $(M=2.5$, on a scale of $1-4$, anchored by "Always" and "Never"), have strong technological skills (when it comes to using the Internet and social media platforms $)(M=6$, on a scale of 1-7, anchored by "Not very strong" and "Very strong"), and frequently consult friends and family and positive online reviews (roughly $75 \%$ of participants) when they shop online. The descriptive statistics suggest that participants in the sample had relevant experience in the online retail context and were appropriate participants for this study.

\section{Test of Hypotheses}

A 2 (WOM vs. eWOM) x 2 (positive vs. negative outcome) MANOVA was performed using the different potential objects of attributions as dependent variables. The overall MANOVA was significant $(\mathrm{F}(9,396)=6.161, p<.001)$. As predicted, the overall models used to predict attribution to the retailer $(\mathrm{F}(3,133)=5.431, p<$ $.001)$ and attribution to friends $(\mathrm{F}(3,133)=6.839, p<.001)$ were significant. The model that predicted attribution to self was also significant $(\mathrm{F}(3,133)=13.403, p$ 
$<.001)$. Mean comparisons were then examined. The results are shown in Table 1.

Table 1. Mean Comparisons (study 1).

\begin{tabular}{|c|c|c|c|c|}
\hline & \multicolumn{4}{|c|}{ Conditions } \\
\hline Attribution & $\begin{array}{l}\text { Positive } \\
\text { eWOM } \\
(\mathrm{N}=33)\end{array}$ & $\begin{array}{l}\text { Negative } \\
\text { eWOM } \\
(\mathrm{N}=33)\end{array}$ & $\begin{array}{l}\text { Positive } \\
\text { WOM } \\
(\mathrm{N}=35)\end{array}$ & $\begin{array}{l}\text { Negative } \\
\text { WOM } \\
(\mathrm{N}=35)\end{array}$ \\
\hline Retailer & $\begin{array}{l}\mathrm{M}=5.06 \\
\mathrm{Sd}=1.32\end{array}$ & $\begin{array}{l}3.97 \\
1.47\end{array}$ & $\begin{array}{l}5.05 \\
1.24\end{array}$ & $\begin{array}{l}4.23 \\
1.57\end{array}$ \\
\hline Reviewer/Friend & $\begin{array}{l}4.27 \\
1.59\end{array}$ & $\begin{array}{l}4.24 \\
1.37\end{array}$ & $\begin{array}{l}5.74 \\
1.4\end{array}$ & $\begin{array}{l}4.60 \\
1.90\end{array}$ \\
\hline Self & $\begin{array}{l}4.21 \\
1.58\end{array}$ & $\begin{array}{l}2.88 \\
1.83\end{array}$ & $\begin{array}{l}5.31 \\
1.28\end{array}$ & $\begin{array}{l}3.80 \\
1.71\end{array}$ \\
\hline
\end{tabular}

Pairwise comparisons show support for four of the six hypotheses. H1, which predicts that when a review is made offline (WOM), attribution to the friend is more likely when post purchase outcome is positive $(M=5.74)$ rather than negative $(M=$ 4.60) was supported $(\mathrm{t}(69)=24.69, p<.001) . \mathrm{H} 2$, which predicted that when a review is made offline, attribution to the retailer is most likely when the outcome is negative, was not supported. The results suggest that when a review is made offline (WOM), attribution to the retailer is less likely when post purchase outcome is negative ( $\mathrm{M}=$ 4.23) rather than positive $(\mathrm{M}=5.06 ; \mathrm{t}(69)=24.67, p=.015)$.

H3 was supported. When a recommendation is made online (eWOM), attribution to the retailer is more likely when post purchase outcome is positive ( $\mathrm{M}=$ 5.06) rather than negative $(\mathrm{M}=3,97 ; \mathrm{t}(65)=24.60, p=.002)$. H4 predicted that when a recommendation is made online (eWOM), attribution to the reviewer is more likely 
when post purchase outcome is negative $(M=4.24)$ rather than positive $(M=4.27)$. This was not supported $(p=.938)$.

H5 and H6 were both supported, demonstrating that consumers will be more willing to take credit for a successful purchase. Attribution to self is more likely when the purchase outcome is positive, regardless of communication method. For eWOM, attribution to self was more likely when the outcome was positive $(\mathrm{M}=4.21)$ than when the outcome was negative $(\mathrm{M}=2.88 ; \mathrm{t}(65)=15.79, p<.001)$. The same was true for WOM. Consumers were more likely to attribute the positive outcome $(\mathrm{M}=$ 5.31) to themselves than the negative outcome $(\mathrm{M}=3.80 ; \mathrm{t}(69)=22.67, p<.001)$.

Figure 3. Outcome Attribution

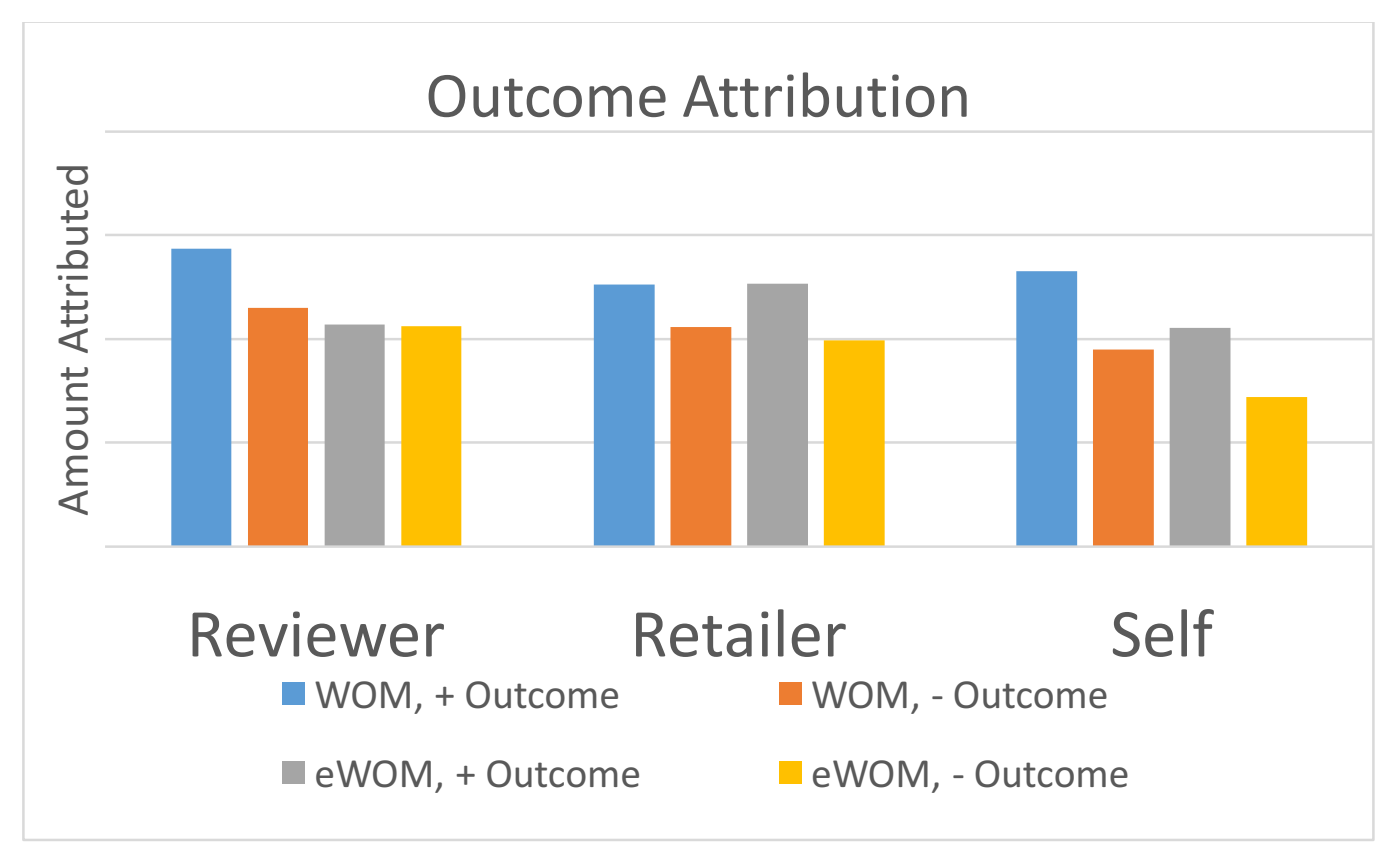

Additional Analyses

The cognitive responses were coded based on the core reason for the reviewer making the recommendation. There were two independent coders and disagreements 
were resolved by discussion (interrater reliability was .95). Answers like "my taste is different from theirs" and "we like different things" were coded as personal differences (between the participant and the reviewer). Other responses were central to product quality (coded: Quality Product), while many respondents were concerned with fake or sponsored reviews (Employee/Company reviews and Sponsored reviews).

Cognitive responses indicate what has commonly been found in the literaturethat participants believed friends would make recommendations that were in their best interest. This belief was seen by $100 \%$ of participants responding that the product was recommended due to its quality, the recommenders love of the product, and their belief their friend would also love it. This belief of behaving in a friends best interest was found even if the experience was negative. Ninety-one percent of respondents believed the product was recommended for the right reasons. Of the remaining $9 \%$, $6 \%$ of respondents did not know why their friends recommended the product, while $3 \%$ suspected the retailer incentivized the friends.

Online, the overall belief that someone recommended the product for unselfish reasons was not as apparent, specifically for the negative condition. Table 2 demonstrates that in the positive WOM and eWOM scenarios, the most common reason for the recommendation was product quality or the reviewers liking the product. For the negative WOM condition (review from friends) the friends liking the product was also predominantly thought to be the reason for the positive review ( $70 \%)$. In total, $91 \%$ of respondents in the positive eWOM condition believed the recommendation was made with unselfish or helpful intentions including their love of the product and their belief others would love it as well. Several participants (9\%) 
mentioned that the reviews may be fake or sponsored by the retailer. In the negative eWOM condition this number increases to $50 \%$, with participants suspecting either fake reviews or incentives from the retailer. This is interesting because despite suspecting fake reviews as a manipulation by the retailer, attribution was still greater for the reviewer than the retailer itself.

Table 2: Reasons for friends/reviewers making positive recommendations

\begin{tabular}{|l|c|c|c|c|}
\hline & $\begin{array}{c}\text { Positive } \\
\text { eWOM } \\
(\mathrm{N}=32)\end{array}$ & $\begin{array}{c}\text { Negative } \\
\text { eWOM } \\
(\mathrm{N}=30)\end{array}$ & $\begin{array}{c}\text { Positive } \\
\text { WOM } \\
(\mathrm{N}=31)\end{array}$ & $\begin{array}{c}\text { Negative } \\
\text { WOM } \\
(\mathrm{N}=34)\end{array}$ \\
\hline Good Product & $91 \%$ & $0 \%$ & $10 \%$ & $6 \%$ \\
\hline $\begin{array}{l}\text { They liked the } \\
\text { product }\end{array}$ & $0 \%$ & $0 \%$ & $87 \%$ & $70 \%$ \\
\hline Personal Differences & $0 \%$ & $50 \%$ & $3 \%$ & $15 \%$ \\
\hline $\begin{array}{l}\text { Employee/ } \\
\text { company reviews }\end{array}$ & $9 \%$ & $37 \%$ & $0 \%$ & $0 \%$ \\
\hline Sponsored reviews & $0 \%$ & $13 \%$ & $0 \%$ & $3 \%$ \\
\hline Don't Know & $0 \%$ & $0 \%$ & $0 \%$ & $6 \%$ \\
\hline Total (N=127) & $100 \%$ & $100 \%$ & $100 \%$ & $100 \%$ \\
\hline
\end{tabular}

\section{Discussion}

Study 1 demonstrates that review modality (online vs. offline) and the valence of the purchase outcome (positive vs. negative) change attribution of credit or blame for the purchase outcome to the retailer, reviewer, or consumer. As expected, friends are credited with recommending a product they believe another friend will like. When a review is made offline (WOM), attribution to the friends is more likely when post purchase outcome is positive rather than negative. Online (eWOM), when there is a lack of relationship with the reviewers, retailers receive more credit for a positive 
purchase outcome than blame for a negative outcome. Contrary to expectations, there was some evidence that friends were not protected from blame. This may be due to the operationalization of the "friends." Due to the difficulty in controlling for closeness between friends and relationship with the source, participants were not instructed to think of specific friends and relationships were not measured. It is possible the lack of association with any real friends led to a lack of protection for the imaginary friend. The results also demonstrated that while online, the reviewers received more blame for an unsuccessful purchase compared to self or the retailer, yet there was not a significant difference between the credit they received for a positive purchase outcome and the blame they received for a negative one. This result suggests an overall lack of affect due to the anonymity/lack of relationship with the reviewer.

The idea that reviews from online reviewers can result in more credit given to the retailer for a successful product outcome and less blame given to the retailer for a negative product outcome points to a previously unexplored benefit of providing online reviews on ecommerce sites. Research has shown that online reviews can lead to increased sales however, the marketing literature has shown that what happens after a purchase can be just as important. This study finds that even in the event of a negative outcome, online reviews can help diminish blame to the retailer. This result is especially true when online reviews are from strangers.

This study provides evidence for not only using online reviews, but maintaining a separation between retailer or review sites and social media sites. Some review sites have begun to let you connect to your social circle and see reviews from your friends. Other sites provide in depth information about the reviewers (photos, 
interests, body types, age). This study suggests that retailers should reconsider using strategies that encourage a relationship between the consumer and the reviewer.

There are several limitations to this study, despite using a student population that shops online and is familiar with using online reviews, they are not representative of the entire consumer market. Also, this study used hypothetical scenarios. It would be beneficial to replicate these results in an actual purchasing situation in order to gain more realistic insights. Lastly, this study uses a relatively inexpensive product (t-shirt) and should be tested on other product categories. Studies two and three attempt to build on this by testing a more expensive/higher quality product (scarf).

While study 1 shows that retailers can protect themselves from the attribution of blame following a negative purchase outcome, there may be other ways for retailers to use reviews to their benefit. Study 2 investigates whether consumer identification with the retailer works with online reviewers to provide an even stronger buffer for ecommerce retailers when product outcomes are negative. 


\section{CHAPTER 5}

\section{STUDY TWO}

\section{Overview}

The objective of this study is to measure the change in where blame lies (Online Retailer, Reviewer or Self) due to who reviewed the product online $\left(\mathrm{eWOM}_{\text {stranger }} \mathrm{vs}\right.$. $\left.\mathrm{eWOM}_{\text {friend }}\right)$ and whether or not the consumer identifies with the retailer (Identification with retailer vs. No identification with retailer). Specifically, whether attribution of blame for a negative purchase outcome is affected by the review source (stranger or friend) and whether the review source interacts with the respondent's identification with the retailer $(\mathrm{H} 7-\mathrm{H} 9)$. Hypothesis 7 suggests that reviewers will get more of the blame when the online reviews come from strangers rather than friends. Hypothesis 8 suggests that retailers will get more blame when the online reviews come from friends rather than strangers. However, hypothesis 9 suggests that if the reviews on a retailer's website come from strangers, attribution of blame to the retailer is higher when the consumer does not identify with the retailer compared to when s/he does.

Study 2 consists of a $2 \times 2$ between-subjects full factorial experimental design which manipulates whether the reviews are communicated online via a friend or a stranger and whether the participants identify with the retailer or not. One hundred and eighty participants completed this study using Amazon's Mechanical Turk.

\section{Method}

Procedure 
Participants were tested by completing an online survey using Amazon Mechanical Turk. When they clicked the link, they read an informed consent document and agreed to participate in the study. In order to manipulate retailer identification, participants in the identification condition were instructed to think about a retailer "that you frequently visit and with which you feel connected. In other words, you perceive a great deal of overlap between who you are and what you stand for and who the brand is and what it stands for." The lower identification condition respondents were only instructed to think of an apparel retailers' website that they frequently visit. They were also instructed to focus on a specific retailer, such as North Face, Macy's, or Banana Republic, as opposed to a marketplace like Amazon or Etsy. Then, as used by Bartz \& Lydon (2004, p .70), participants were asked to think of a time they recently shopped on the website and to write a sentence or two about their thoughts and feelings regarding themselves and their relationship to this retailer.

Next, in order to measure their level of identification, participants were asked to describe the level of overlap between their identity and the retailer's identity (Bagozzi \& Dholakia, 2006), followed by a series of questions pertaining to the participants' relationship with the retailer. All participants viewed written scenarios, which have been employed in prior services research (e.g. Bitner, 1990; Voss, Parasuraman \& Grewal, 1998). The scenario either suggested the reviews were provided online by three friends $\left(\mathrm{eWOM}_{\text {friend }}\right.$ condition) or online by three reviewers

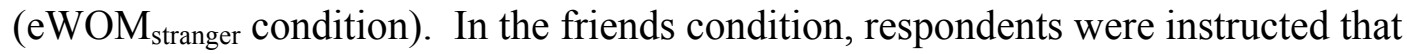
their friends would be referred to as reviewers going forward. To control for expectations, participants were asked how satisfied they expected to be with the 
product (scarf) on a 1-7 scale with extremely dissatisfied and extremely satisfied as endpoints.

They were then instructed to assume they purchased the product from the online retailer and were dissatisfied with the purchase:

Despite the reviewers' satisfaction with the scarf, you are dissatisfied with the purchase. It does not meet your minimum expectations.

The manipulation was tested in an exploratory pre-test $(\mathrm{N}=36)$, which showed $95 \%$ of participants were anywhere from somewhat dissatisfied to extremely dissatisfied with their purchase.

Dependent Variables

The dependent variables of interest were the attribution of blame to the reviewer and the retailer. With options of friends or online reviewers, retailer, self and random chance, participants were asked: "To what do you attribute your satisfaction (dissatisfaction)?" This was followed by asking how much they attributed their satisfaction (dissatisfaction) to the retailer, friends or reviewers, self, and random chance on a 0-6 scale with "not at all" and "completely" as endpoints. Participants were then asked to rate a series of statements based on McAuley, Duncan and Russell (1992). Three items were used to measure attribution of blame to the self $(\alpha=.80)$, three items were used to measure attribution of blame to the reviewers $(\alpha=.90)$, and three items were used to measure attribution of blame to the retailer $(\alpha=.94)$. The measures associated with each attribution object were averaged to created three separate scores. These items were followed by another series of statements about the participants' behavioral intentions towards the retailer (Cronin, Brady \& Hult, 2000; $\alpha$ 
$=.97)$.

Additional Measures

An attention check item was included to make sure the respondents were carefully reading each item. Covariates of familiarity with online shopping, technological skills, gender and age were evaluated and not found to be significant ( $\mathrm{p}>.30)$, so they are not included in the analysis. Participants were also asked "How much of an effect does your purchase dissatisfaction have on your expectation to purchase from this retailer in the future?" with options of No effect, less likely and more likely to purchase again. Participants were asked how likely they would be to try another product that was recommended by these friends (reviewers on this retailers' website) on a 0-6 scale (not at all likely-very likely). Cognitive responses were included in order to better understand consumer processing. Participants were asked: "Why do you think your friends (the reviewers) highly recommended the product and yet you were dissatisfied?"

\section{Results}

All participants were screened for their online shopping experience and if they consult online reviews prior to making a purchase. Anyone who had no experience shopping online or using reviews was not allowed to respond to the other items. Respondents who did not respond correctly to the attention check, the review source manipulation check, or the item which asked them to list an online retailer that was not a marketplace, like Amazon, were eliminated from further analysis.

The usable sample consisted of 162 participants using Amazon's Mechanical Turk (55\% female, aged 20-72). Sixty-five percent of participants indicated that they 
shop online frequently $(\mathrm{M}=2.1$, on a scale of $1-4$, anchored by "Always" and "Never"), and have strong technological skills (when it comes to using the Internet and social media platforms $)(\mathrm{M}=5.94$, on a scale of $1-7$, anchored by "Not very strong" and "Very strong"). The descriptive statistics suggest that participants in the sample had relevant experience in the online retail context and were appropriate participants for this study.

Three items were used as a manipulation check for the identification variable. The items had good internal consistency $(\alpha=.81)$, so they were averaged to create a score. The respondents in the higher identification group $(M=4.96)$ had significantly higher identification scores than respondents in the lower identification groups $(\mathrm{M}=$ $4.4 ; \mathrm{F}(1,161)=7.12, \mathrm{p}=.008)$.

Hypotheses Tests

Two separate ANOVA's were performed using attribution of blame to the reviewer and attribution of blame to the retailer as the dependent variables and the review source (friend vs. stranger) and high vs. low identification with the retailer as independent variables. The first ANCOVA was used to test H7, which predicted respondents would attribute more blame to reviewers when they were strangers than when they were friends. It used attribution of blame to the reviewer as the dependent variable, the review source as the independent variable, and identification, time spent online, attribution to random chance, and purchase satisfaction as covariates. The ANCOVA was not significant $(\mathrm{F}(5,156)=1.68, \mathrm{p}>.10)$, and $\mathrm{H} 7$ was not supported.

The second ANCOVA used attribution to the retailer as the dependent variable and review source and identification with the retailer as the independent variables, and 
time spent online, attribution to random chance, and purchase satisfaction as covariates. The ANCOVA was significant $(\mathrm{F}(6,155)=3.50, \mathrm{p}=.003)$. Identification had a significant relationship with attribution of blame toward the retailer $(\mathrm{F}(1,155)=$ $4.7, \mathrm{p}=.03$ ), such that respondents who did not identify with the firm were significantly more likely $(\mathrm{M}=4.22)$ to blame the firm than respondents who identified with the firm ( $M=3.66$, where the responses were reverse coded for interpretation), so H8 was supported. Belief that random chance was a factor was the only significant covariate $(\mathrm{p}<.001)$. The interaction between review source and identification was not significant $(\mathrm{p}>.20)$ and $\mathrm{H} 9$ was not supported.

\section{Additional Analyses}

Cognitive responses for study 2 are similar to those of study 1 . The cognitive responses were coded based on the core reason for the reviewer making the recommendation. There were two independent coders and disagreements were resolved by discussion (interrater reliability was .97). Answers like "my taste in fashion is different" and "we prefer different things" were coded as "Different tastes" (between the participant and the reviewer), which represented $35 \%$ of the responses. Nearly $30 \%$ of participants believed the reviewers recommended the product because they legitimately liked it. Some responses were more surprising like 7\% of respondents believing they got a bad scarf despite the reviewer getting a good one or that their standards are much higher than those of the reviewers (9\%). Roughly $15 \%$ of respondents were concerned with fake or sponsored reviews.

A one-way ANOVA with identification and reviewer type as the dependent variables was $F(5,157)=1.435$ overall, and shows a marginally significant main effect 
for reviewer type (friend vs. stranger) $(\mathrm{F}(5,157)=1.965, \mathrm{p}=.087$ but not between the identification/no identification conditions $(\mathrm{p}=.215)$. When the review is from a friend, participants were less likely to believe the reviews were fake or incentivized ( $9 \%$ in the friend conditions vs. $20 \%$ in the online reviewer conditions). Identifying with the retailer did not significantly impact this with the same number of participants in each condition believing they may have read fake reviews (14\% identification vs $16 \%$ no identification). One-third of participants who read reviews from friends believed the friend was making the recommendation because they legitimately liked the product, compared to $25 \%$ of those who read a review from an online reviewer.

Six behavioral intention measures were averaged to create one behavioral intentions score. A regression was run using behavioral intentions as the dependent variable and identification with the retailer, attribution to the reviewer, retailer, and random chance as well as overall satisfaction as independent variables. Results show that attribution of blame to the retailer has a significant effect on behavioral intentions $(\mathrm{F}(6,156)=7.574, \mathrm{p}<.001)$. The more blame is attributed to the retailer, the less likely participants were to want to shop with, spend money on or recommend this retailer. Identification with the retailer is significant $(\mathrm{p}=.001)$, as well as attribution to the retailer (.005). Attribution to the reviewer was marginally significant $(\mathrm{p}=.058)$ (See Table 3). 
Table 3. Regression results

\begin{tabular}{|l|c|c|c|c|c|}
\hline & $\mathrm{B}$ & $\begin{array}{c}\text { Std. } \\
\text { Error }\end{array}$ & $\begin{array}{c}\text { Standardized } \\
\text { Coefficients } \\
\text { Beta }\end{array}$ & $\mathrm{t}$ & $\mathrm{Sig}$. \\
\hline Constant & 1.615 & .672 & & 2.403 & .017 \\
\hline Identification & .268 & .081 & .238 & 3.324 & .001 \\
\hline Attribution to self & -.132 & .087 & -.131 & -1.509 & .133 \\
\hline Attribution to the reviewer & .173 & .091 & .160 & 1.909 & .058 \\
\hline Attribution to the retailer & .208 & .073 & .228 & 2.836 & .005 \\
\hline $\begin{array}{l}\text { Attribution to random } \\
\text { chance }\end{array}$ & .098 & .059 & .128 & 1.663 & .098 \\
\hline Overall satisfaction & .108 & .125 & .064 & .863 & .390 \\
\hline
\end{tabular}

\section{Discussion}

Study 2 found another benefit of online reviews, specifically as it relates to respondents who identify with a firm. Those who do were significantly less likely to blame the firm for a negative purchase outcome. This is important as the literature shows many decisions about a product and a company are made post-purchase. To support this, post-hoc analysis shows that if a consumer identifies with the retailer, and a purchase outcome is not positive, the consumer will still be likely to behave positively towards that retailer (purchase from them in the future, recommend them etc.). When a consumer does not identify with the retailer however, if they blame them for a negative purchasing experience, they will be less likely to have positive future behavioral intentions.

The cognitive responses show some evidence of there being more trust to the friend than the online reviewer, contrary to recent studies (Fretwell et al., 2013; 
BrightLocal, 2014). More people who bought a product based on an online recommendation and were unhappy, attributed their dissatisfaction to the possibility of fake/incentivized reviews. This was less likely to be the case for a friend.

This study provides further evidence for companies that online reviews can help their business, specifically by decreasing blame for a negative outcome for those who identify with the retailer. This is relevant to the literature as it offers another way retailers can protect themselves, and another reason to utilize online reviews. It also supports the previous literature on the benefits of consumer identification with the retailer. Retailers could use this to encourage loyal customers to read reviews, send them emails that directly contain online reviews, and specifically encourage these customers to shop online.

There are several limitations to this study. There is some disagreement in the literature about the generalizability of MTurk populations, despite the participants being familiar with shopping online and using reviews. Also, participants imagined going through the scenarios. No actual purchase was made, decreasing the realness of the situation. Lastly, this study utilized an accessory. This study could be replicated using electronics, or household goods to see if the results extend to other product categories.

While this study found that identifying with the retailer can help protect them in a negative post purchase context, it is possible that this effect does not always hold true. Research shows that when a retailer commits what a consumer believes to be a significant violation, and the consumer identifies with that retailer, they will actually 
be more upset than a normal consumer would be (Einwiller et al., 2006; Schmalz and Orth, 2012; Trump, 2014).

Study 3 attempts to test incentivization as a potential boundary condition. If identifying consumers believe that the reviewers were paid to write reviews, and then the purchase outcome is negative, will the consumer blame the retailer more, or will identifying with the retailer still protect that retailer from blame? This is managerially relevant as the FTC mandates that reviewers disclose if an incentive is given to write a review, and it is common practice now for consumers to receive a free product, discount, refund etc. for writing a review. Also, the results of studies 1 and 2 show that consumers are concerned that positive reviews may be written by someone who was incentivized. 


\section{CHAPTER 6}

\section{STUDY THREE}

\section{Overview}

The objective of this study is to measure the change in where blame lies (Online Retailer, Reviewer or Self) when a product is purchased due to online reviewers who were or were not incentivized to write the reviews, when the customer identifies or does not identify with the retailer. Specifically, whether attribution of blame for a negative purchase outcome is affected by the reviewers being incentivized by the retailer (H10) and whether or not incentivizing a reviewer interacts with the identification to the retailer to increase the amount of blame given to the retailer (H11). Hypothesis 10 suggests that incentives for consumer reviews increase attribution of blame to the retailer following a negative purchase outcome. However, hypothesis 11 suggests that identification with the retailer moderates the relationship between incentives and attribution of blame to the retailer, such that identification with the retailer increases the blame attributed to the retailer.

Study 3 consists of a 2 x 2 between-subjects full factorial experimental design, which manipulates whether the reviewers were incentivized and whether or not the participants identify with the retailer. One hundred and eighty participants completed this study using Amazon's Mechanical Turk.

\section{Method}

\section{Procedure}

Participants were tested by completing an online survey using Amazon 
Mechanical Turk. When they clicked the link, they read an informed consent document and agreed to participate in the study. In order to manipulate retailer identification, participants in the identification condition were instructed to think about a retailer "that you frequently visit and with which you feel connected. In other words, you perceive a great deal of overlap between who you are and what you stand for and who the brand is and what it stands for." The lower identification condition respondents were only instructed to think of an apparel retailers' website that they frequently visit. They were also instructed to focus on a specific retailer, such as North Face, Macy's, or Banana Republic, as opposed to a marketplace like Amazon or Etsy. Then as used by Bartz \& Lydon (2004, p .70), participants were asked to think of a time they recently shopped on the website and to write a sentence or two about their thoughts and feelings regarding themselves and their relationship to this retailer.

Next, in order to measure their level of identification, participants were asked to describe the level of overlap between their identity and the retailer's identity (Bagozzi \& Dholakia, 2006), followed by a series of questions pertaining to the participants' relationship with the retailer. All participants viewed written scenarios, which have been employed in prior services research (e.g. Bitner, 1990; Voss, Parasuraman \& Grewal, 1998). The scenarios suggested the reviews were provided online by three reviewers. In order to manipulate reviewer incentives, the incentivized conditions had a disclosure included with their reviews: The reviewers received a $\$ 10$ store credit in exchange for their reviews. To control for expectations, participants were asked how satisfied they expected to be with the product (scarf) on a 1-7 scale with extremely satisfied and extremely dissatisfied as endpoints. 
They were then instructed to assume they purchased the product from the online retailer and were dissatisfied with the purchase:

Despite the reviewer' satisfaction with the scarf, you are dissatisfied with the purchase. It does not meet your minimum expectations.

The manipulations were tested in an exploratory pre-test $(\mathrm{N}=34)$, which showed $97 \%$ of participants were anywhere from somewhat dissatisfied to extremely dissatisfied with their purchase.

Dependent Variables

The dependent variable of interest is the attribution of blame to the retailer. With options of friends or online reviewers, retailer, self and random chance, participants were asked: “To what do you attribute your satisfaction (dissatisfaction)?" This was followed by asking how much they attributed their satisfaction (dissatisfaction) to the retailer, friends or reviewers, and self on a 0-6 scale with "not at all" and "completely" as endpoints. Participants were then asked to rate a series of statements based on McAuley, Duncan and Russell (1992). Three items were used to measure attribution of blame to the retailer $(\alpha=.94)$. The measures were averaged to create a score. These items were followed by another series of statements about the participants' behavioral intentions towards the retailer (Cronin, Brady \& Hult, 2000; $\alpha=.97)$.

\section{Additional Measures}

An attention check item was included to make sure the respondents were carefully reading each item. Covariates of familiarity with online shopping, technological skills, gender and age were evaluated and not found to be significant 
( $p>35)$, so they are not included in the analysis. Participants were also asked "How much of an effect does your purchase dissatisfaction have on your expectation to purchase from this retailer in the future?" with options of No effect, less likely and more likely to purchase again. Participants were asked how likely they would be to try another product that was recommended by these reviewers on this retailers' website on a 0-6 scale (not at all likely-very likely). Cognitive responses were included in order to better understand consumer processing. Participants were asked: "Why do you think the reviewers highly recommended the product and yet you were dissatisfied?"

\section{Results}

All participants were screened for their online shopping experience and if they consult online reviews prior to making a purchase. Anyone who had no experience shopping online or using reviews was not allowed to respond to the other items. Respondents who did not respond correctly to the attention check, the review source manipulation check, or the item which asked them to list an online retailer that was not a marketplace, like Amazon, were eliminated from further analysis.

The usable sample consisted of 152 participants using Amazon's Mechanical Turk (59\% female, aged 20-74). Sixty-two percent of participants indicated that they shop online frequently ( $\mathrm{M}=1.95$, on a scale of $1-4$, anchored by "Always" and "Never"), and have strong technological skills (when it comes to using the Internet and social media platforms $)(\mathrm{M}=6.05$, on a scale of $1-7$, anchored by "Not very strong" and "Very strong"). The descriptive statistics suggest that participants in the 
sample had relevant experience in the online retail context and were appropriate participants for this study.

Three items were used as a manipulation check for the identification variable. The items had good internal consistency $(\alpha=.81)$, so they were averaged to create a score. The respondents in the higher identification group $(M=4.96)$ had significantly higher identification.

\section{Test of Hypotheses}

An ANOVA was performed using whether or not the reviewer was given an incentive and high vs. low identification with the retailer as independent variables and attribution of blame to the retailer as the dependent variable. A marginally significant main effect was found for incentivization (.076). The results show support for H10, suggesting that respondents who read incentivized consumer reviews $(M=2.46)$ were significantly more likely to blame the retailer following a negative purchase outcome when compared to those who did no read an incentivized consumer review $(\mathrm{M}=$ 2.797, where the responses were reverse coded for interpretation).

Next, an ANCOVA was used to test H11, which predicted that Identification with the retailer moderates the relationship between incentives and attribution of blame to the retailer, such that identification with the retailer increases the blame attributed to the retailer. It used attribution of blame to the retailer as the dependent variable, the use of an incentive and high vs. low identification as the independent variables, using time spent online, attribution to random chance, and purchase satisfaction as covariates. When controlling for these variables, there was a significant interaction effect $(\mathrm{F}(1,146)=3.854, \mathrm{p}=.05)$ (Figure 5). 
Figure 4. Attribution of blame to the retailer

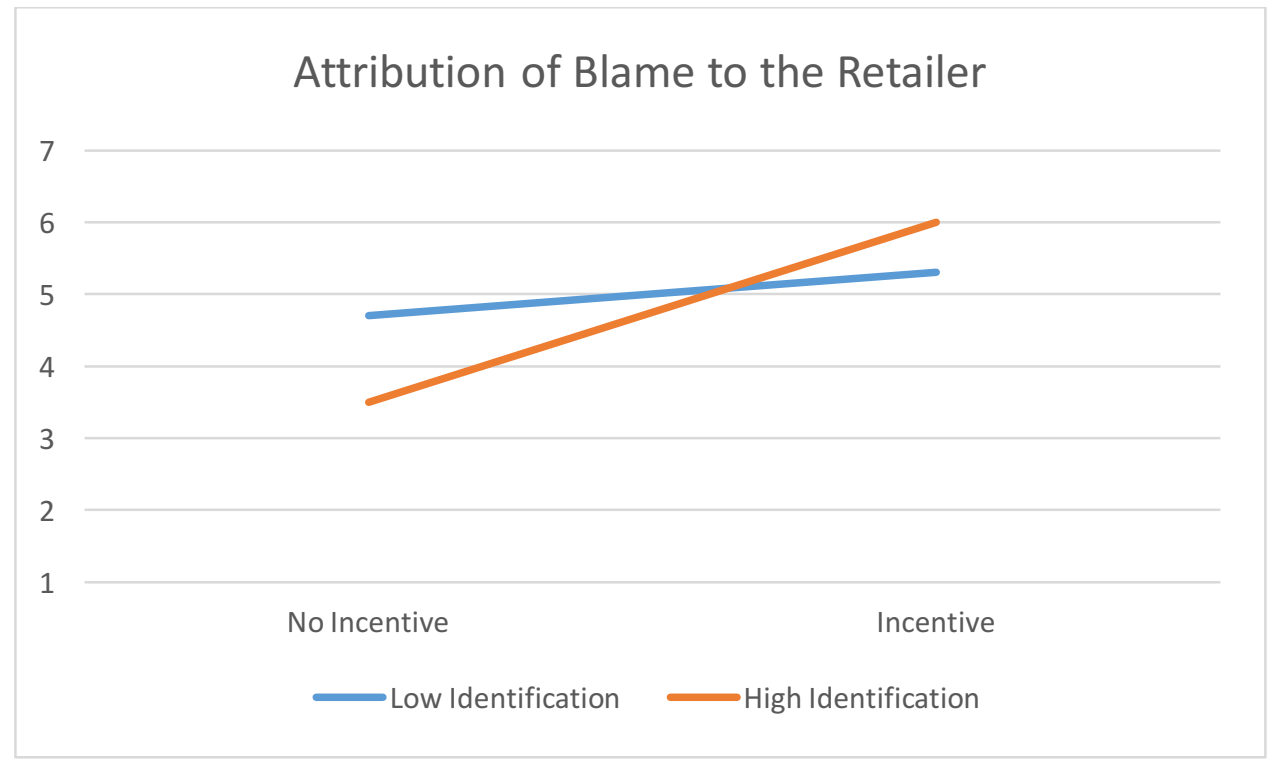

Additional Analyses

Cognitive responses for study 3 are similar to those of studies 1 and 2 . The cognitive responses were coded based on the core reason for the reviewer making the recommendation. There were two independent coders and disagreements were resolved by discussion (interrater reliability was .96). Answers like "my taste in fashion is different" and "we prefer different things" were coded as "Different tastes" (between the participant and the reviewer), which represented 18\% of the responses. Other results were similar to study 2 with $5 \%$ of participants believing they got a bad/defective scarf despite the reviewer getting a good one (coded: They got a higher quality scarf), and 6\% believing the reviewer had lower standards. Not surprisingly, nearly half (47\%) of respondents were concerned with fake or sponsored reviews.

A one-way ANOVA shows a main effect for the incentive conditions $(\mathrm{F}(1,144)=75.190, \mathrm{p}<.001)$ only. This makes sense as the incentive conditions were told that participants were incentivized. Nearly $80 \%$ of participants in the 
incentivization conditions cited the reviewer being paid as the main motivation for the product being recommended.

\section{Discussion}

Study 3 provides a boundary condition for the protections of consumer identification with the retailer. Despite identification protecting the retailer from blame when post purchase evaluation is negative, if the reviewer has been incentivized the consumer blames the retailer more than consumers that do not identify with the retailer. This demonstrates a difficulty that has been found both in the literature and in practice: incentivizing consumers to write reviews can lead to more reviews in general and also more helpful reviews (Gonçalves, 2012). However, when the consumer knows that the reviewer has been incentivized, they no longer find the review unbiased, therefore mitigating the helpfulness of the review. This negative effect of incentivization is even more significant for consumers who identify with the retailer.

This negative impact of incentivization complicates things for companies, now that the FTC requires disclosure of any incentives given for a review (2009). There are ethical and legal implications for not disclosing the incentives, however, consumers are currently not viewing incentivized reviews in a positive light. This is shown through the cognitive responses with nearly $80 \%$ of those in the incentivization condition blaming their negative purchasing experience on the fact that the reviewer was incentivized to write the review.

The more ubiquitous incentivized reviews are, the more people may accept them, but currently there is a dilemma for companies. Researchers should continue to 
look at different types of incentives and find if some strategies work at making reviews appear less bias than others.

This study has similar limitations to study 2, using MTurk, hypothetical scenarios and one product category. The primary focus of this study is looking at incentivized reviews. Today, companies do this in many ways, by offering free samples of products, complementary gifts, rebates, gift cards etc. This study only uses one incentivization method (store credit). It would be beneficial to test others as well. As long as incentivized reviews continue to be less trusted, researchers should look at other ways to get people to write reviews. 


\section{CHAPTER 7}

\section{CONCLUSION}

The results of three studies have demonstrated that while online reviews can be helpful to retailers, there are circumstances in which they may be detrimental.

Study 1 findings show that when a product is recommended to someone, whether it be by a friend or an online reviewer, the retailer gets credit for a successful purchase, while avoiding some of the blame for a negative outcome. Study 2 looks at identification with the retailer, finding that identifying with the retailer leads consumers to blame the retailer less when there is a negative purchase outcome. Study 3 first shows that when consumers read incentivized reviews and then the purchase outcome is negative, they are more likely to blame the retailer (than if they were to read a review from someone who was not incentivized). Study 3 also discovers a boundary condition for the positive impact of retailer identification. When identifying with the retailer and reading an incentivized review, if the purchase outcome is negative, even more blame is attributed to the retailer.

These findings have significant implications for the WOM literature. First, they demonstrate a connection between previously explored moderators (source and valence) and purchase outcome attribution that has not been looked at. Studies 2 and 3 also highlight two previously unexplored moderators- retailer identification and incentivization- and show their impact on outcome attribution. Behavioral intention measures support previous attribution literature, finding that increased blame to the 
retailer lowers a consumer's likelihood to purchase from or recommend this retailer in the future.

In agreement with the online review literature, study 1 shows support for retailers using online reviews. Retailers receive credit for positive purchase outcomes, and are able to avoid some of the blame for negative purchase outcomes. This is important, as it generates positive consumer post-purchase behaviors (the overall goal for retailers). The retailer identification findings (consistent with the literature) from study 2 encourage retailers to target consumers who identify with their company, as these consumers are less likely to blame the retailer for a negative purchase outcome. This also supports the idea of creating more retailer identification amongst consumers. Loyal customers have been a key factor throughout marketing history, however creating a feeling of identification can be more difficult than just keeping repeat customers. For retailers to create identification they need to have core principles that consumers can not only appreciate and relate to, but identify with. The stronger and more clear a retailer's identity is, the more likely it is that consumers can recognize the similarities they share and feel as if they are a part of the brand itself.

While study 2 emphasizes the positive impact of retailer identification, study 3 shows a clear downside. If identifying consumers read incentivized reviews, and then experience a negative purchase outcome, they are more likely to blame the retailer. If retailers are going to offer incentives to reviewers, they should attempt to limit who sees incentivized reviews, so they are only shown to first time shoppers, or shoppers who do not feel a close affiliation with the brand. This will limit potentially negative results even when a consumer is unhappy with their purchase. 
Study 3 also offers more evidence of the incentivization difficulties retailers are experiencing. Online reviews lead to more sales and therefore retailers need consumers to write reviews. Many consumers do not write reviews, however, and without incentivization, retailers are unable to get the benefit online reviews offer. The FTC mandate (and subsequent monitoring) of incentive disclosure means that seeing a reviewer was incentivized is still relatively new for consumers. At some point, consumers may be able to see past the bias that comes with the incentive, especially due to research showing these reviews are frequently more accurate and helpful. In the meantime, retailers should consider alternative (legal) ways to encourage consumers to write reviews. Some websites will enter you in a contest so that in reality most reviewers do not win anything and are simply writing a review, receiving nothing in return. Utilizing those who identify with the company may also be beneficial, as those who feel closer may be more willing to help.

This set of studies has only begun to scratch the surface of outcome attribution in an online shopping context. There are many more avenues that would benefit from future research. This study focuses specifically on retailer websites, however Amazon and etsy are successful retailers who sell products from other "brands." This leads to a new source of attribution. Not only should we focus on the retailer selling the product, but also the brand that makes the product. There are many examples of products being bought off Amazon that turned out to be not at all similar to what the consumer believed they were purchasing. This most likely does not deter people from shopping on Amazon, only it encourages them to choose products more carefully, preferably from better known or higher quality brands. 
The set-up of these studies could be changed in order to create more realistic shopping situations. Due to the nature of social identity theory and strength ties, it can be difficult to measure relationship closeness with multiple individuals and how that relationship impacts credit or blame in a purchasing situation, especially while controlling for the relevance of that friend making a recommendation (while some friends may know a lot about clothing, others would not be ideal to seek shopping recommendations from). If this could be more directly measured or manipulated, there would be more evidence of exactly how "social" retailers should be. Should they in fact let you see what your online friends are buying (this is the current direction in which many sites are moving), or if friends are shielded more from blame, it is likely retailers should stay away from making connections with a consumers social network?

There are other ways online reviews are becoming more social. These studies looked at reviews in one context (the retailer's website), yet today you can read product recommendations on review sites, social media sites, discussion boards, personal websites etc. Due to previous studies finding disagreement based on using different online platforms, these results should be replicated using other platforms.

Another way reviews are becoming more social is the use of video. A brief visit to YouTube and you can view a wide array of review videos on everything from beauty products to video games. Being able to watch someone give an account of a product or service, and the ability to comment and read others comments on these videos is vastly different from the typical anonymous review on a website. The implications of this setup would also be important to consider for future research. 
Product category is an important area in which to extend the current literature. These studies use a t-shirt and a scarf. Other types of products at various price points should be used. Price is of great importance to marketing researchers and would also be beneficial to consider. We know that a higher cost product creates more risk and therefore should lead to more blame when something goes wrong. This can be tested in the online review context by utilizing products in different price ranges. Another unique pricing issue that deserves attention is the idea of "free." In today's digital environment, there are many reviews for products that are "free' for instance free apps, events, website content, music etc. How does this impact attribution for the reviewer as well as the retailer?

While online shopping seems destined to continue its growth, these new issues are important to consider both for researchers and practitioners. It is essential that we understand how consumers are responding before we make significant changes when it comes to our online review systems. If in fact recommendations from strangers are the most helpful to retailers, this should be their main focus. Adopting methods of creating more of a bond between the consumer and the reviewer may sound like a good thing, but in reality may only lead to more negative feelings towards the retailer. 


\section{APPENDICES}

APPENDIX A: WOM LITERATURE REVIEW

\begin{tabular}{|c|c|c|c|c|c|}
\hline Authors (Year) & $\begin{array}{l}\text { Paper Type } \\
\text { (Conceptual, } \\
\text { Empirical) }\end{array}$ & $\begin{array}{l}\text { Theoretical/Conceptual } \\
\text { Base(s) }\end{array}$ & $\begin{array}{l}\text { Context } \\
\text { (Online, } \\
\text { Offline) }\end{array}$ & Construct & Antecedent/Outcome \\
\hline \multirow{2}{*}{$\begin{array}{l}\text { He and Bond } \\
(2015)\end{array}$} & \multirow[t]{2}{*}{ Empirical } & Social Distribution & \multirow[t]{2}{*}{ Online } & Review Dispersion & $\mathrm{A}$ \\
\hline & & Attribution Theory & & $\begin{array}{l}\text { Attribution (reason for } \\
\text { dispersion) }\end{array}$ & A (Mediator) \\
\hline \multirow[t]{5}{*}{ Koo (2015) } & \multirow[t]{5}{*}{ Empirical } & $\begin{array}{l}\text { Electronic Word of } \\
\text { Mouth }\end{array}$ & \multirow[t]{5}{*}{ Online } & Review Valence & $\mathrm{A}$ \\
\hline & & \multirow[t]{4}{*}{ The Negativity Bias } & & Tie Strength & A (Moderator) \\
\hline & & & & Service Type & A (Moderator) \\
\hline & & & & Attitude towards service & $\mathrm{O}$ \\
\hline & & & & Intention to buy service & $\mathrm{O}$ \\
\hline \multirow{3}{*}{$\begin{array}{l}\text { You, Vadakkepatt, } \\
\text { \& Joshi (2015) }\end{array}$} & \multirow{3}{*}{ Conceptual } & \multirow{3}{*}{$\begin{array}{l}\text { Electronic Word of } \\
\text { Mouth }\end{array}$} & \multirow{3}{*}{ Online } & Industry Growth & $\mathrm{A}$ \\
\hline & & & & Industry Competition & $\mathrm{A}$ \\
\hline & & & & Expertise of WOM Platform & $\mathrm{A}$ \\
\hline
\end{tabular}




\begin{tabular}{|c|c|c|c|c|c|}
\hline Authors (Year) & $\begin{array}{l}\text { Paper Type } \\
\text { (Conceptual, } \\
\text { Empirical) }\end{array}$ & $\begin{array}{l}\text { Theoretical/Conceptual } \\
\text { Base(s) }\end{array}$ & $\begin{array}{l}\text { Context } \\
\text { (Online, } \\
\text { Offline) }\end{array}$ & Construct & Antecedent/Outcome \\
\hline \multirow{10}{*}{$\begin{array}{l}\text { Packard and Berger } \\
\text { (2015) }\end{array}$} & & & & $\begin{array}{l}\text { Trustworthiness of WOM } \\
\text { Platform }\end{array}$ & $\mathrm{A}$ \\
\hline & & & & Advertising & $\mathrm{A}$ \\
\hline & & & & Price & $\mathrm{A}$ \\
\hline & & & & Distribution & $\mathrm{A}$ \\
\hline & & & & eWOM Volume & $\mathrm{O}$ \\
\hline & & & & eWOM Valence & $\mathrm{O}$ \\
\hline & \multirow[t]{4}{*}{ Empirical } & \multirow[t]{4}{*}{ Word of Mouth } & \multirow[t]{4}{*}{ Online } & Endorsement Style & $\mathrm{A}$ \\
\hline & & & & Consumer Knowledge & $\mathrm{A}$ \\
\hline & & & & $\begin{array}{l}\text { Perception of Sender } \\
\text { Expertise }\end{array}$ & A (Mediator) \\
\hline & & & & Product Choice & $\mathrm{O}$ \\
\hline \multirow{7}{*}{$\begin{array}{l}\text { Pentina, Bailey and } \\
\text { Zhang (2015) }\end{array}$} & \multirow[t]{7}{*}{ Empirical } & \multirow[t]{7}{*}{ Word of Mouth } & \multirow[t]{7}{*}{ Online } & Review Valence & $\mathrm{A}$ \\
\hline & & & & Review Sidedness & $\mathrm{A}$ \\
\hline & & & & $\begin{array}{l}\text { Perceived Similarity with the } \\
\text { Reviewer }\end{array}$ & A (Moderator) \\
\hline & & & & User Regulatory Focus & $\mathrm{A}$ \\
\hline & & & & Message Characteristics & $\mathrm{A}$ \\
\hline & & & & Attitudinal Variables & $\mathrm{O}$ \\
\hline & & & & Purchase Intentions & $\mathrm{O}$ \\
\hline
\end{tabular}




\begin{tabular}{|c|c|c|c|c|c|}
\hline Authors (Year) & $\begin{array}{l}\text { Paper Type } \\
\text { (Conceptual, } \\
\text { Empirical) }\end{array}$ & $\begin{array}{l}\text { Theoretical/Conceptual } \\
\text { Base(s) }\end{array}$ & $\begin{array}{l}\text { Context } \\
\text { (Online, } \\
\text { Offline) }\end{array}$ & Construct & Antecedent/Outcome \\
\hline & & & & $\begin{array}{l}\text { User Perceptions of } \\
\text { Helpfulness }\end{array}$ & $\mathrm{O}$ \\
\hline & & & & $\begin{array}{l}\text { User Perceptions of } \\
\text { Trustworthiness }\end{array}$ & $\mathrm{O}$ \\
\hline & & & & Credibility of the Review & $\mathrm{O}$ \\
\hline \multirow{5}{*}{ Xu (2014) } & \multirow{5}{*}{ Empirical } & \multirow[t]{5}{*}{ Credibility } & \multirow{5}{*}{ Online } & Profile Picture & A \\
\hline & & & & Source Credibility & $\mathrm{A}$ \\
\hline & & & & Review Valence & $\mathrm{A}$ \\
\hline & & & & Affective Trust & $\mathrm{O}$ \\
\hline & & & & Cognitive Trust & $\mathrm{O}$ \\
\hline \multirow{8}{*}{ Berger (2014) } & \multirow{8}{*}{ Conceptual } & Reactance Theory & \multirow{8}{*}{ Both } & Identity-Signaling & A \\
\hline & & Attribution Theory & & Filling Conversational Space & A \\
\hline & & Emotion Regulation & & Generating Social Support & A \\
\hline & & Impression Management & & Venting & $\mathrm{A}$ \\
\hline & & $\begin{array}{l}\text { Persuasion and Attitude } \\
\text { Change }\end{array}$ & & Facilitating Sense Making & A \\
\hline & & & & Reducing Dissonance & A \\
\hline & & & & Taking Vengeance & $\mathrm{A}$ \\
\hline & & & & Encouraging Rehearsal & A \\
\hline
\end{tabular}




\begin{tabular}{|c|c|c|c|c|c|}
\hline Authors (Year) & $\begin{array}{l}\text { Paper Type } \\
\text { (Conceptual, } \\
\text { Empirical) }\end{array}$ & $\begin{array}{l}\text { Theoretical/Conceptual } \\
\text { Base(s) }\end{array}$ & $\begin{array}{l}\text { Context } \\
\text { (Online, } \\
\text { Offline) }\end{array}$ & Construct & Antecedent/Outcome \\
\hline & & & & Seeking Advice & $\mathrm{A}$ \\
\hline & & & & Reinforcing Shared Views & $\mathrm{A}$ \\
\hline & & & & $\begin{array}{l}\text { Reducing Loneliness and } \\
\text { Social Exclusion }\end{array}$ & $\mathrm{A}$ \\
\hline & & & & Tie Strength & A (Moderator) \\
\hline & & & & Audience Size & A (Moderator) \\
\hline & & & & Tie Status & A (Moderator) \\
\hline & & & & Written vs. Oral & A (Moderator) \\
\hline & & & & Identifiability & A (Moderator) \\
\hline \multirow{5}{*}{$\begin{array}{l}\text { Yadav and Pavlou } \\
\text { (2014) }\end{array}$} & \multirow[t]{5}{*}{ Conceptual } & \multirow{5}{*}{$\begin{array}{l}\text { Computer Mediated } \\
\text { Environments }\end{array}$} & \multirow[t]{5}{*}{ Online } & Firm-Firm Interactions & $\mathrm{A}$ \\
\hline & & & & Firm-Consumer Interactions & $\mathrm{A}$ \\
\hline & & & & Consumer-Firm Interactions & $\mathrm{A}$ \\
\hline & & & & $\begin{array}{l}\text { Consumer-Consumer } \\
\text { Interactions }\end{array}$ & $\mathrm{A}$ \\
\hline & & & & Marketing Outcomes & $\mathrm{O}$ \\
\hline \multirow[t]{2}{*}{$\begin{array}{l}\text { King, Racherla and } \\
\text { Bush (2014) }\end{array}$} & \multirow[t]{2}{*}{ Conceptual } & $\begin{array}{l}\text { Information Processing } \\
\text { Theory }\end{array}$ & \multirow[t]{2}{*}{ Online } & Self-Enhancement & $\mathrm{A}$ \\
\hline & & & & Consumer Psychographics & A \\
\hline
\end{tabular}




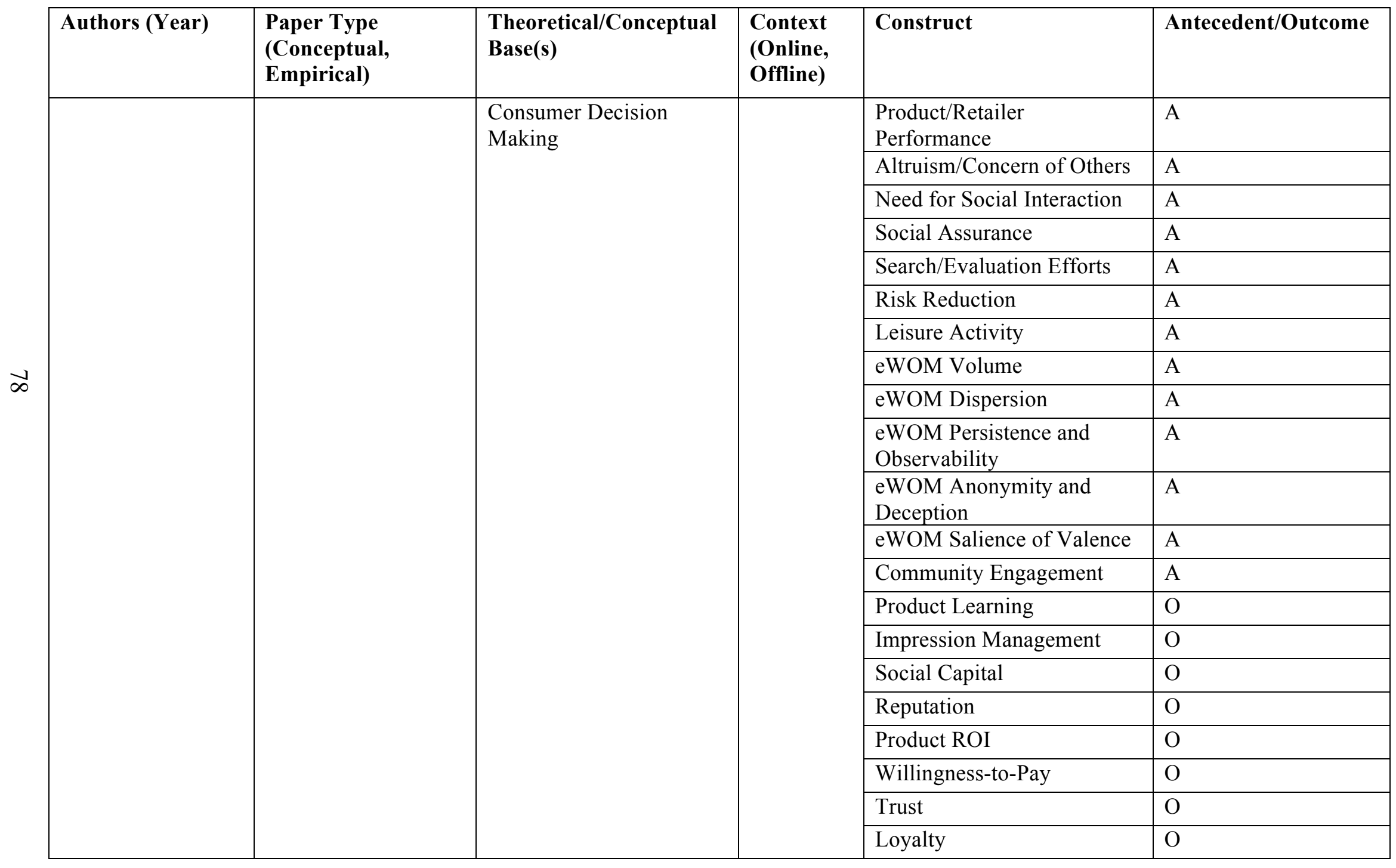




\begin{tabular}{|c|c|c|c|c|c|}
\hline Authors (Year) & $\begin{array}{l}\text { Paper Type } \\
\text { (Conceptual, } \\
\text { Empirical) }\end{array}$ & $\begin{array}{l}\text { Theoretical/Conceptual } \\
\text { Base(s) }\end{array}$ & $\begin{array}{l}\text { Context } \\
\text { (Online, } \\
\text { Offline) }\end{array}$ & Construct & Antecedent/Outcome \\
\hline \multirow[t]{12}{*}{$\begin{array}{l}\text { Blazevic et al. } \\
\text { (2013) }\end{array}$} & \multirow[t]{12}{*}{ Conceptual } & $\begin{array}{l}\text { Customer Driven } \\
\text { Influence }\end{array}$ & \multirow[t]{12}{*}{ Online } & Involvement & A (Moderator) \\
\hline & & \multirow[t]{11}{*}{ Attribution Theory } & & Level of Arousal & A (Moderator) \\
\hline & & & & Observability & A (Moderator) \\
\hline & & & & $\begin{array}{l}\text { Own Attitude Towards } \\
\text { Brand }\end{array}$ & A (Moderator) \\
\hline & & & & Homophily & A (Moderator) \\
\hline & & & & Availability & A (Moderator) \\
\hline & & & & Helping the Company & $\mathrm{A}$ \\
\hline & & & & Self-Enhancement & $\mathrm{A}$ \\
\hline & & & & Group Association & $\mathrm{A}$ \\
\hline & & & & $\begin{array}{l}\text { Group } \\
\text { Association/dissociation }\end{array}$ & $\mathrm{A}$ \\
\hline & & & & $\begin{array}{l}\text { Recommendation } \\
\text { (Intentional/unintentional } \\
\text { communication) }\end{array}$ & $\mathrm{O}$ \\
\hline & & & & Consumption & $\mathrm{O}$ \\
\hline \multirow{3}{*}{$\begin{array}{l}\text { Ludwig, et al. } \\
\text { (2013) }\end{array}$} & \multirow[t]{3}{*}{ Empirical } & \multirow[t]{3}{*}{ Affective Content } & \multirow[t]{3}{*}{ Online } & Affective Cues & $\mathrm{A}$ \\
\hline & & & & Evaluation Valence & $\mathrm{A}$ \\
\hline & & & & Product Judgements & $\mathrm{O}$ \\
\hline
\end{tabular}




\begin{tabular}{|c|c|c|c|c|c|}
\hline Authors (Year) & $\begin{array}{l}\text { Paper Type } \\
\text { (Conceptual, } \\
\text { Empirical) }\end{array}$ & $\begin{array}{l}\text { Theoretical/Conceptual } \\
\text { Base(s) }\end{array}$ & $\begin{array}{l}\text { Context } \\
\text { (Online, } \\
\text { Offline) }\end{array}$ & Construct & Antecedent/Outcome \\
\hline & & & & Product Choice & $\mathrm{O}$ \\
\hline \multirow{2}{*}{$\begin{array}{l}\text { Chen and Lurie } \\
\text { (2013) }\end{array}$} & \multirow{2}{*}{ Empirical } & Attribution Theory & \multirow{2}{*}{ Online } & Review Valence & $\mathrm{A}$ \\
\hline & & & & $\begin{array}{l}\text { Attributions to } \\
\text { reviewer/product }\end{array}$ & A (Mediator) \\
\hline \multirow[t]{4}{*}{$\mathrm{Wu}(2013)$} & \multirow[t]{4}{*}{ Empirical } & $\begin{array}{l}\text { Electronic Word of } \\
\text { Mouth }\end{array}$ & \multirow[t]{4}{*}{ Online } & Review Valence & $\mathrm{A}$ \\
\hline & & The Negativity Bias & & Review Length & $\mathrm{A}$ \\
\hline & & & & Readibility & $\mathrm{A}$ \\
\hline & & & & Helpfulness of Reviews & $\mathrm{O}$ \\
\hline $\begin{array}{l}\text { Floh, Koller and } \\
\text { Zauner (2013) }\end{array}$ & Empirical & Word of Mouth & Online & Valence Intensity & $\mathrm{A}$ \\
\hline \multirow{10}{*}{$\begin{array}{l}\text { Trenz and Berger } \\
\text { (2013) }\end{array}$} & \multirow[t]{10}{*}{ Conceptual } & \multirow{10}{*}{$\begin{array}{l}\text { Electronic Word of } \\
\text { Mouth }\end{array}$} & \multirow[t]{10}{*}{ Online } & Product & $\mathrm{A}$ \\
\hline & & & & Price & $\mathrm{A}$ \\
\hline & & & & Sales & $\mathrm{A}$ \\
\hline & & & & Release Date & $\mathrm{A}$ \\
\hline & & & & Average Rating & $\mathrm{A}$ \\
\hline & & & & Number of Reviews & $\mathrm{A}$ \\
\hline & & & & Review Rating & $\mathrm{A}$ \\
\hline & & & & Review Length & $\mathrm{A}$ \\
\hline & & & & Review Helpfulness & $\mathrm{A}$ \\
\hline & & & & Reviewer Details & $\mathrm{A}$ \\
\hline
\end{tabular}




\begin{tabular}{|c|c|c|c|c|c|}
\hline Authors (Year) & $\begin{array}{l}\text { Paper Type } \\
\text { (Conceptual, } \\
\text { Empirical) }\end{array}$ & $\begin{array}{l}\text { Theoretical/Conceptual } \\
\text { Base(s) }\end{array}$ & $\begin{array}{l}\text { Context } \\
\text { (Online, } \\
\text { Offline) }\end{array}$ & Construct & Antecedent/Outcome \\
\hline & & & & Date and Time & $\mathrm{A}$ \\
\hline & & & & Effect on Sales & $\mathrm{O}$ \\
\hline & & & & Bias and Fraud & $\mathrm{O}$ \\
\hline \multirow{5}{*}{$\begin{array}{l}\text { Berger and Iyengar } \\
\text { (2013) }\end{array}$} & \multirow{5}{*}{ Empirical } & \multirow{5}{*}{ Word of Mouth } & \multirow{5}{*}{ Offline } & Oral Communication & A (Moderator) \\
\hline & & & & Written Communication & A (Moderator) \\
\hline & & & & Asynchrony & A (Mediator) \\
\hline & & & & Self-Enhancement & $\mathrm{A}$ \\
\hline & & & & What People Share & $\mathrm{O}$ \\
\hline $\begin{array}{l}\text { Kusumasondjaja et } \\
\text { al. (2012) }\end{array}$ & Empirical & Credibility & Online & Trust & $\mathrm{O}$ \\
\hline \multirow{7}{*}{$\begin{array}{l}\text { Cheung and Lee } \\
\text { (2012) }\end{array}$} & \multirow[t]{7}{*}{ Empirical } & eWOM Communication & \multirow[t]{7}{*}{ Online } & Reputation & $\mathrm{A}$ \\
\hline & & Economic Theory & & Reciprocity & $\mathrm{A}$ \\
\hline & & \multirow[t]{5}{*}{ Knowledge Self-Efficacy } & & Sense of Belonging & $\mathrm{A}$ \\
\hline & & & & Enjoyment of Helping & $\mathrm{A}$ \\
\hline & & & & Moral Obligation & $\mathrm{A}$ \\
\hline & & & & Knowledge Self-Efficacy & $\mathrm{A}$ \\
\hline & & & & Consumers WOM Intention & $\mathrm{O}$ \\
\hline
\end{tabular}




\begin{tabular}{|c|c|c|c|c|c|}
\hline Authors (Year) & $\begin{array}{l}\text { Paper Type } \\
\text { (Conceptual, } \\
\text { Empirical) }\end{array}$ & $\begin{array}{l}\text { Theoretical/Conceptual } \\
\text { Base(s) }\end{array}$ & $\begin{array}{l}\text { Context } \\
\text { (Online, } \\
\text { Offline) }\end{array}$ & Construct & Antecedent/Outcome \\
\hline \multirow[t]{4}{*}{$\begin{array}{l}\text { Zhao and Xie } \\
\text { (2011) }\end{array}$} & \multirow[t]{4}{*}{ Empirical } & $\begin{array}{l}\text { Psychological } \\
\text { Distance/Fit }\end{array}$ & \multirow[t]{4}{*}{ Offline } & Temporal Distance & $\mathrm{A}$ \\
\hline & & Social Distance & & Recommendation Relevance & A (Mediator) \\
\hline & & \multirow[t]{2}{*}{ Temporal Distance } & & Recommendation Source & A (Moderator) \\
\hline & & & & Preferences & $\mathrm{O}$ \\
\hline \multirow{5}{*}{$\begin{array}{l}\text { De Angelis et al. } \\
\text { (2011) }\end{array}$} & \multirow{5}{*}{ Empirical } & \multirow[t]{5}{*}{ Self-Enhancement } & \multirow{5}{*}{ Online } & Self-Esteem & $\mathrm{A}$ \\
\hline & & & & Attachment & A (Moderator) \\
\hline & & & & WOM Valence & $\mathrm{O}$ \\
\hline & & & & Generating WOM & $\mathrm{O}$ \\
\hline & & & & Transmitting WOM & $\mathrm{O}$ \\
\hline \multirow{4}{*}{ Schlosser (2011) } & \multirow{4}{*}{ Empirical } & \multirow{4}{*}{ Credibility } & \multirow{4}{*}{ Online } & Reviewer Trustworthiness & A (Mediator) \\
\hline & & & & Reviewer Rating & $\mathrm{A}$ \\
\hline & & & & Perceived Helpfulness & $\mathrm{O}$ \\
\hline & & & & Product Judgements & $\mathrm{O}$ \\
\hline \multirow{4}{*}{$\begin{array}{l}\text { Dellarocas, Gao } \\
\text { and Narayan (2010) }\end{array}$} & \multirow[t]{4}{*}{ Empirical } & \multirow{4}{*}{$\begin{array}{l}\text { Interpersonal } \\
\text { Communication }\end{array}$} & \multirow[t]{4}{*}{ Online } & Product Availability & $\mathrm{A}$ \\
\hline & & & & Product Success & $\mathrm{A}$ \\
\hline & & & & Review Volume & $\mathrm{A}$ \\
\hline & & & & Propensity to Review & $\mathrm{O}$ \\
\hline
\end{tabular}




\begin{tabular}{|c|c|c|c|c|c|}
\hline Authors (Year) & $\begin{array}{l}\text { Paper Type } \\
\text { (Conceptual, } \\
\text { Empirical) }\end{array}$ & $\begin{array}{l}\text { Theoretical/Conceptual } \\
\text { Base(s) }\end{array}$ & $\begin{array}{l}\text { Context } \\
\text { (Online, } \\
\text { Offline) }\end{array}$ & Construct & Antecedent/Outcome \\
\hline \multirow{2}{*}{$\begin{array}{l}\text { Chintagunta et al. } \\
(2010)\end{array}$} & \multirow[t]{2}{*}{ Empirical } & \multirow[t]{2}{*}{ Word of Mouth } & \multirow[t]{2}{*}{ Online } & WOM Valence & $\mathrm{A}$ \\
\hline & & & & Sales & $\mathrm{O}$ \\
\hline \multirow{6}{*}{$\begin{array}{l}\text { Zhu and Zhang } \\
\text { (2010) }\end{array}$} & \multirow[t]{6}{*}{ Empirical } & \multirow[t]{6}{*}{ Experiential Goods } & \multirow[t]{6}{*}{ Online } & Product Popularity & A (Moderator) \\
\hline & & & & $\begin{array}{l}\text { Consumer Internet } \\
\text { Experience }\end{array}$ & A (Moderator) \\
\hline & & & & Competition & $\mathrm{A}$ \\
\hline & & & & $\begin{array}{l}\text { Design of online review } \\
\text { system }\end{array}$ & $\mathrm{A}$ \\
\hline & & & & Review Influence & $\mathrm{A}$ \\
\hline & & & & Purchase Outcome & $\mathrm{O}$ \\
\hline \multirow{4}{*}{$\begin{array}{l}\text { Park and Lee } \\
(2009)\end{array}$} & \multirow[t]{4}{*}{ Empirical } & \multirow{4}{*}{$\begin{array}{l}\text { Electronic Word of } \\
\text { Mouth }\end{array}$} & \multirow[t]{4}{*}{ Online } & eWOM Valence & $\mathrm{A}$ \\
\hline & & & & Website Reputation & $\mathrm{A}$ \\
\hline & & & & Product Type & A (Moderator) \\
\hline & & & & eWOM Impact & $\mathrm{O}$ \\
\hline \multirow[t]{7}{*}{$\begin{array}{l}\text { Forman, Ghose and } \\
\text { Wiesenfeld (2008) }\end{array}$} & \multirow[t]{7}{*}{ Empirical } & Online Communities & \multirow[t]{7}{*}{ Online } & $\begin{array}{l}\text { Prevenlence of Identity- } \\
\text { Descriptive Reviewer } \\
\text { Information }\end{array}$ & $\mathrm{A}$ \\
\hline & & \multirow[t]{6}{*}{ Identity } & & Shared Geographic Location & $\mathrm{A}$ \\
\hline & & & & $\begin{array}{l}\text { Identity-Descriptive } \\
\text { Reviewer Information }\end{array}$ & $\mathrm{A}$ \\
\hline & & & & Product Information & A \\
\hline & & & & Review Ambiguity & A (Moderator) \\
\hline & & & & Online Product Sales & $\mathrm{O}$ \\
\hline & & & & Product Choice & $\mathrm{O}$ \\
\hline
\end{tabular}




\begin{tabular}{|c|c|c|c|c|c|}
\hline Authors (Year) & $\begin{array}{l}\text { Paper Type } \\
\text { (Conceptual, } \\
\text { Empirical) }\end{array}$ & $\begin{array}{l}\text { Theoretical/Conceptual } \\
\text { Base(s) }\end{array}$ & $\begin{array}{l}\text { Context } \\
\text { (Online, } \\
\text { Offline) }\end{array}$ & Construct & Antecedent/Outcome \\
\hline & & & & Review Helpfulness & $\mathrm{O}$ \\
\hline \multirow{7}{*}{ Breazeale (2008) } & \multirow{7}{*}{ Conceptual } & \multirow{7}{*}{ Word of Mouth } & \multirow{7}{*}{ Both } & WOM Valence & A (Mediator) \\
\hline & & & & Source Effects & A (Mediator) \\
\hline & & & & Customer Perceptions & A \\
\hline & & & & Service Failures & $\mathrm{A}$ \\
\hline & & & & Customer Acquisition & $\mathrm{O}$ \\
\hline & & & & Customer Retention & $\mathrm{O}$ \\
\hline & & & & Increasing Firm Value & $\mathrm{O}$ \\
\hline \multirow{4}{*}{$\begin{array}{l}\text { East, Hammond } \\
\text { and Lomax (2008) }\end{array}$} & \multirow{4}{*}{ Empirical } & \multirow{4}{*}{ Word of Mouth } & \multirow{4}{*}{ Offline } & Message Content & $\mathrm{A}$ \\
\hline & & & & Tie Strength & $\mathrm{A}$ \\
\hline & & & & Source Effects & $\mathrm{A}$ \\
\hline & & & & WOM Impact & $\mathrm{O}$ \\
\hline \multirow{5}{*}{$\begin{array}{l}\text { Leskovec, Adamic } \\
\text { and Huberman } \\
(2007)\end{array}$} & \multirow[t]{5}{*}{ Empirical } & Social Network Theory & \multirow[t]{5}{*}{ Offline } & Active Recommenders & $\mathrm{A}$ \\
\hline & & \multirow[t]{4}{*}{ Diffusion Theory } & & Recommendation Saturation & $\mathrm{A}$ \\
\hline & & & & Receiver Targeting & $\mathrm{A}$ \\
\hline & & & & Timing & $\mathrm{A}$ \\
\hline & & & & Sales & $\mathrm{O}$ \\
\hline
\end{tabular}




\begin{tabular}{|c|c|c|c|c|c|}
\hline Authors (Year) & $\begin{array}{l}\text { Paper Type } \\
\text { (Conceptual, } \\
\text { Empirical) }\end{array}$ & $\begin{array}{l}\text { Theoretical/Conceptual } \\
\text { Base(s) }\end{array}$ & $\begin{array}{l}\text { Context } \\
\text { (Online, } \\
\text { Offline) }\end{array}$ & Construct & Antecedent/Outcome \\
\hline \multirow{6}{*}{$\begin{array}{l}\text { Dellarocas, Zhang, } \\
\text { Awad (2007) }\end{array}$} & \multirow[t]{6}{*}{ Empirical } & Revenue Forecasting & \multirow[t]{6}{*}{ Online } & Total Sales & A \\
\hline & & \multirow{5}{*}{ Word of Mouth } & & Marketing Budget & $\mathrm{A}$ \\
\hline & & & & Exhibition Longevity & $\mathrm{A}$ \\
\hline & & & & $\begin{array}{l}\text { Volume of first week user } \\
\text { ratings }\end{array}$ & $\mathrm{A}$ \\
\hline & & & & Volume of Critic Ratings & A \\
\hline & & & & Predicting Future Sales & $\mathrm{O}$ \\
\hline $\begin{array}{l}\text { Sen and Lerman } \\
(2007)\end{array}$ & Empirical & Word of Mouth & Online & Review Valence & $\mathrm{A}$ \\
\hline \multirow[t]{2}{*}{ Liu (2006) } & \multirow[t]{2}{*}{ Empirical } & \multirow[t]{2}{*}{ Word of Mouth } & \multirow[t]{2}{*}{ Online } & WOM Volume & $\mathrm{A}$ \\
\hline & & & & Sales & $\mathrm{O}$ \\
\hline \multirow{6}{*}{$\begin{array}{l}\text { Chevalier and } \\
\text { Mayzlin (2006) }\end{array}$} & \multirow[t]{5}{*}{ Empirical } & \multirow[t]{5}{*}{ Word of Mouth } & \multirow[t]{5}{*}{ Online } & Product Rating & $\mathrm{A}$ \\
\hline & & & & Review Length & $\mathrm{A}$ \\
\hline & & & & Price & $\mathrm{A}$ \\
\hline & & & & Number of Reviews & $\mathrm{A}$ \\
\hline & & & & Product Sales & $\mathrm{O}$ \\
\hline & Empirical & Motivation & Online & Product Involvement & A \\
\hline
\end{tabular}




\begin{tabular}{|c|c|c|c|c|c|}
\hline Authors (Year) & $\begin{array}{l}\text { Paper Type } \\
\text { (Conceptual, } \\
\text { Empirical) }\end{array}$ & $\begin{array}{l}\text { Theoretical/Conceptual } \\
\text { Base(s) }\end{array}$ & $\begin{array}{l}\text { Context } \\
\text { (Online, } \\
\text { Offline) }\end{array}$ & Construct & Antecedent/Outcome \\
\hline \multirow{3}{*}{$\begin{array}{l}\text { Dellarocas and } \\
\text { Narayan (2006) }\end{array}$} & & \multirow[t]{3}{*}{ Economic Theory } & & Concern for Others & $\mathrm{A}$ \\
\hline & & & & Self-Involvement & $\mathrm{A}$ \\
\hline & & & & Social Benefits & $\mathrm{A}$ \\
\hline \multirow{4}{*}{$\begin{array}{l}\text { Duan, Gu, } \\
\text { Whinston (2005) }\end{array}$} & \multirow{4}{*}{ Empirical } & \multirow[t]{4}{*}{ Word of Mouth } & \multirow{4}{*}{ Online } & Features & $\mathrm{A}$ \\
\hline & & & & Availability & $\mathrm{A}$ \\
\hline & & & & WOM & $\mathrm{O}$ \\
\hline & & & & Sales & $\mathrm{O}$ \\
\hline \multirow{3}{*}{$\begin{array}{l}\text { Senecal and Nantel } \\
(2004)\end{array}$} & \multirow{3}{*}{ Empirical } & \multirow{3}{*}{ Word of Mouth } & \multirow{3}{*}{ Online } & Recommender System & A (Moderator) \\
\hline & & & & Product Type & A \\
\hline & & & & Product Choice & $\mathrm{O}$ \\
\hline \multirow{5}{*}{$\begin{array}{l}\text { Hennig-Thurau et } \\
\text { al. (2004) }\end{array}$} & \multirow[t]{5}{*}{ Empirical } & \multirow[t]{5}{*}{ Motivation } & \multirow[t]{5}{*}{ Online } & Platform Assistance & $\mathrm{A}$ \\
\hline & & & & Venting Negative Feelings & $\mathrm{A}$ \\
\hline & & & & Concern for Others & $\mathrm{A}$ \\
\hline & & & & $\begin{array}{l}\text { Extraversion/Positive Self- } \\
\text { Enhancement }\end{array}$ & $\mathrm{A}$ \\
\hline & & & & Social Benefits & $\mathrm{A}$ \\
\hline
\end{tabular}




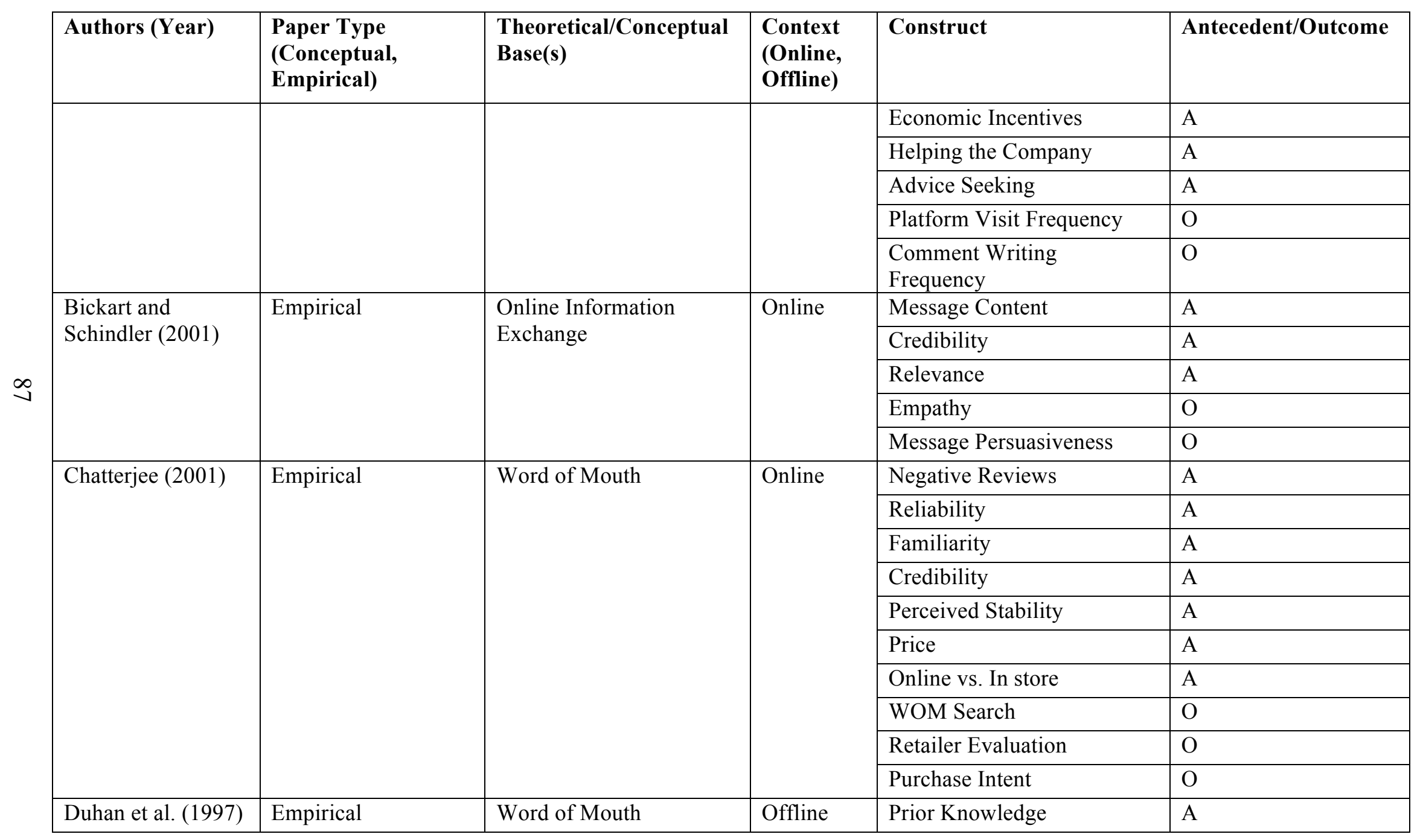




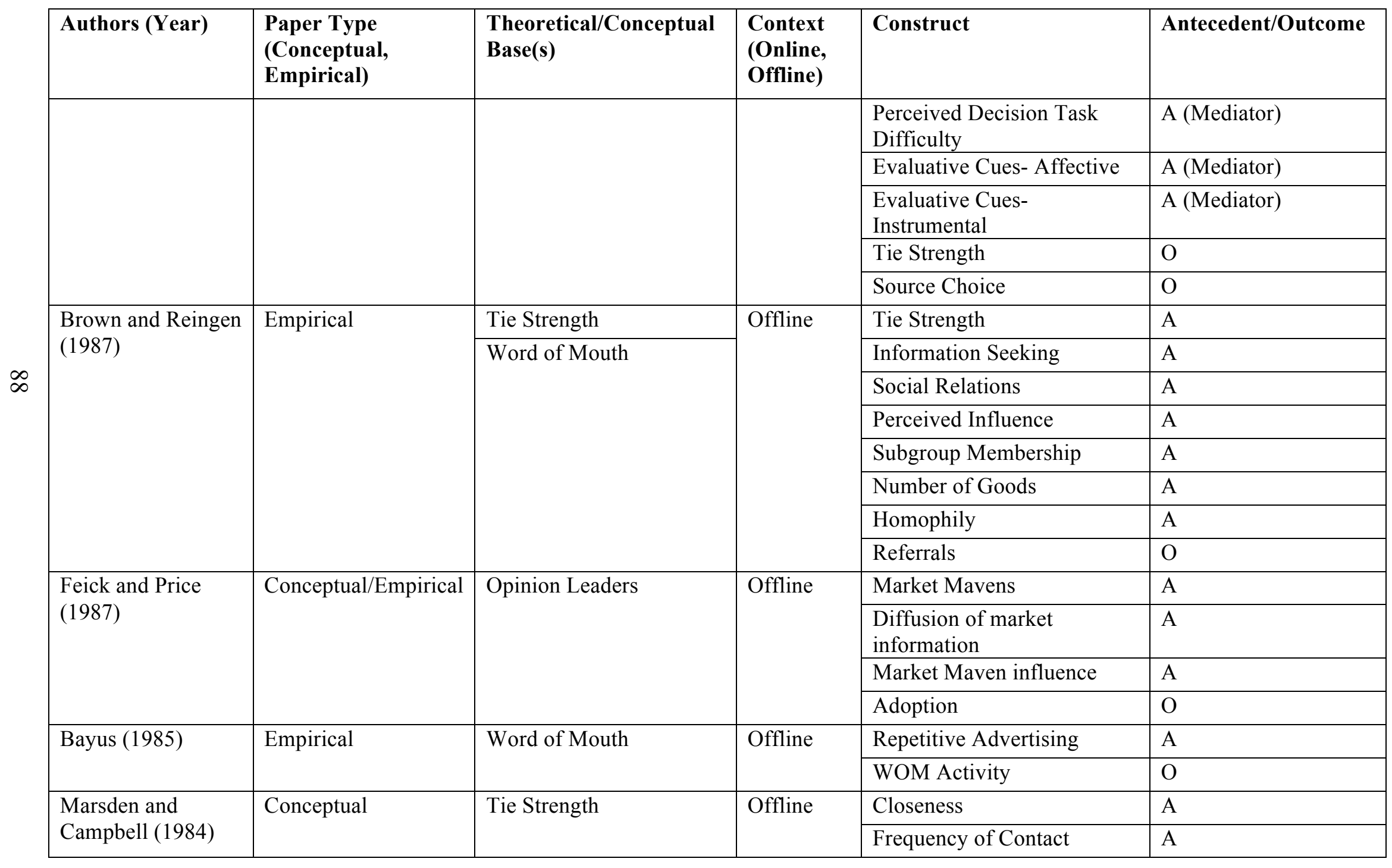




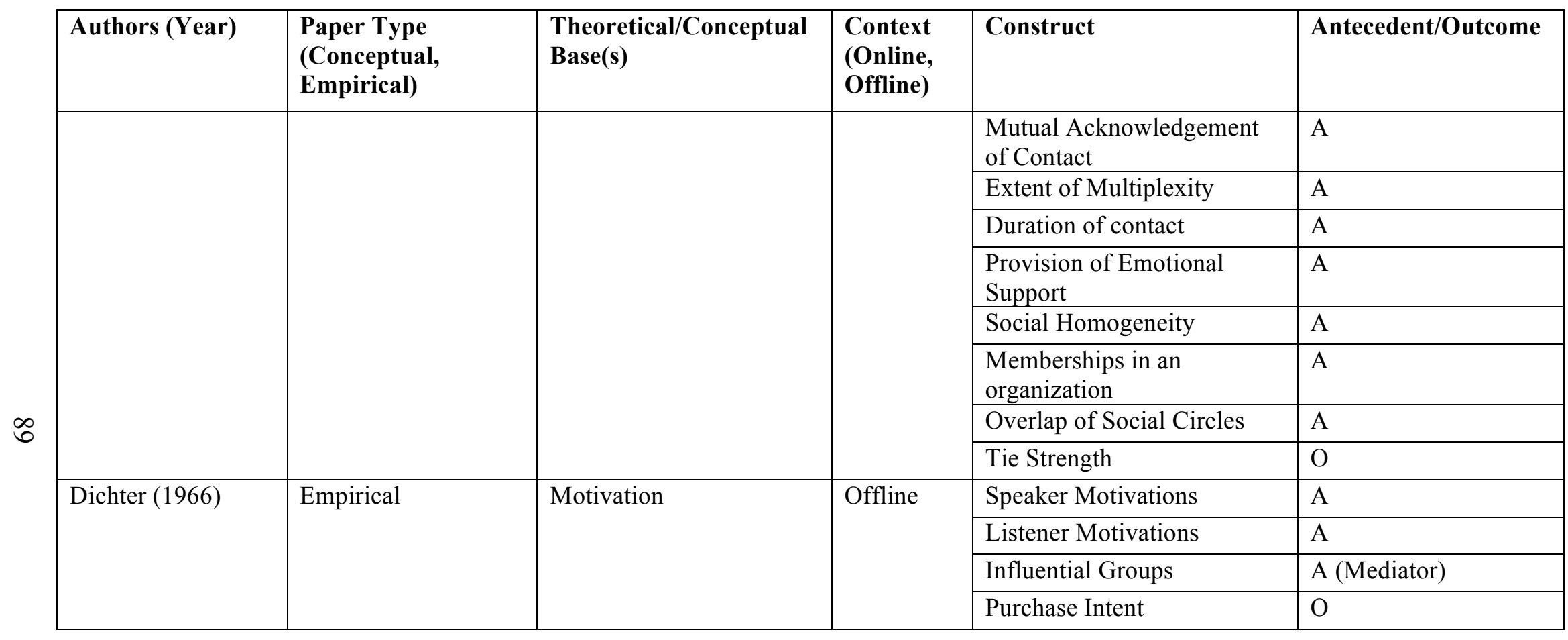




\section{APPENDIX B: ATTRIBUTION OF BLAME LITERATURE REVIEW}

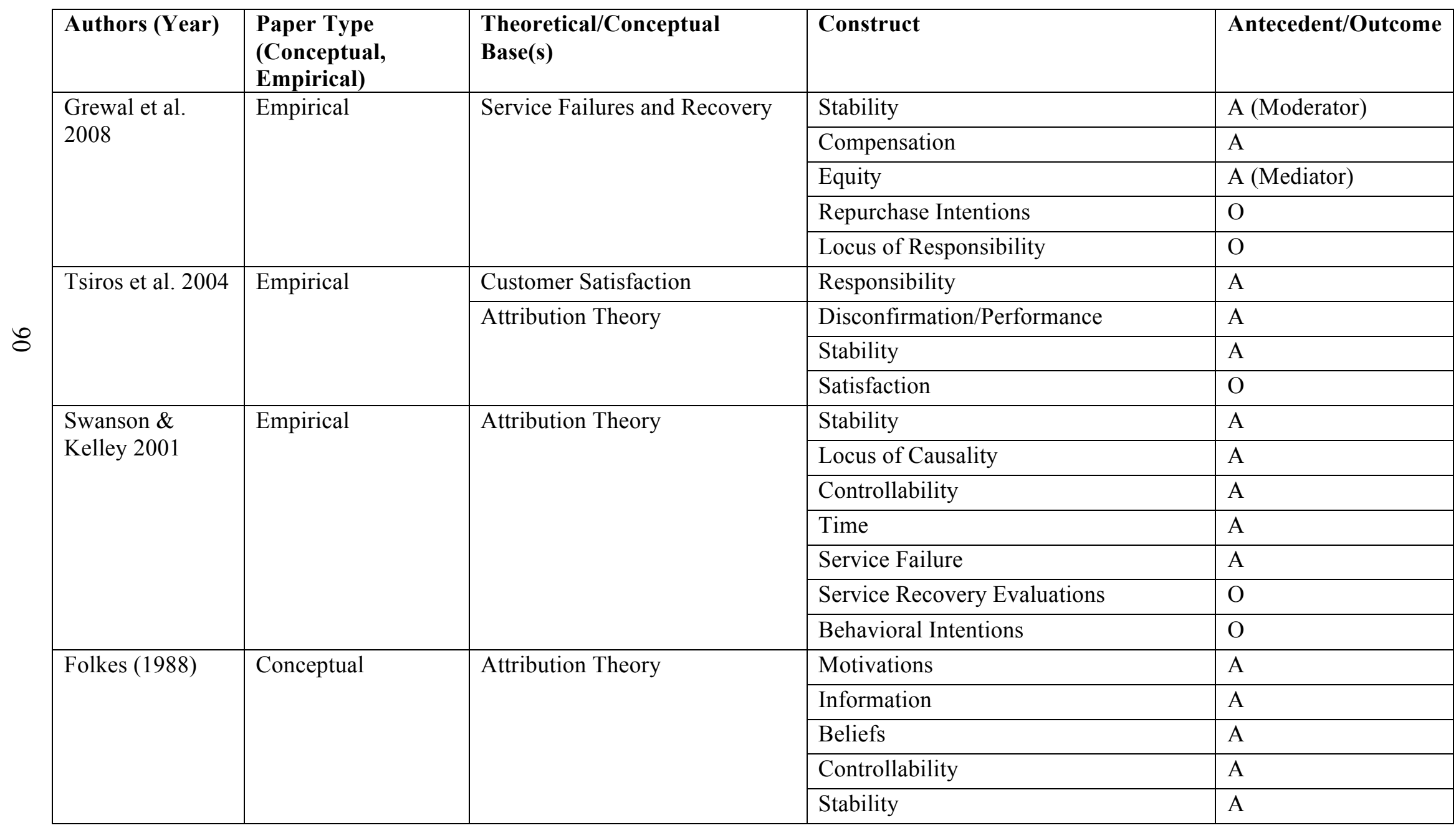




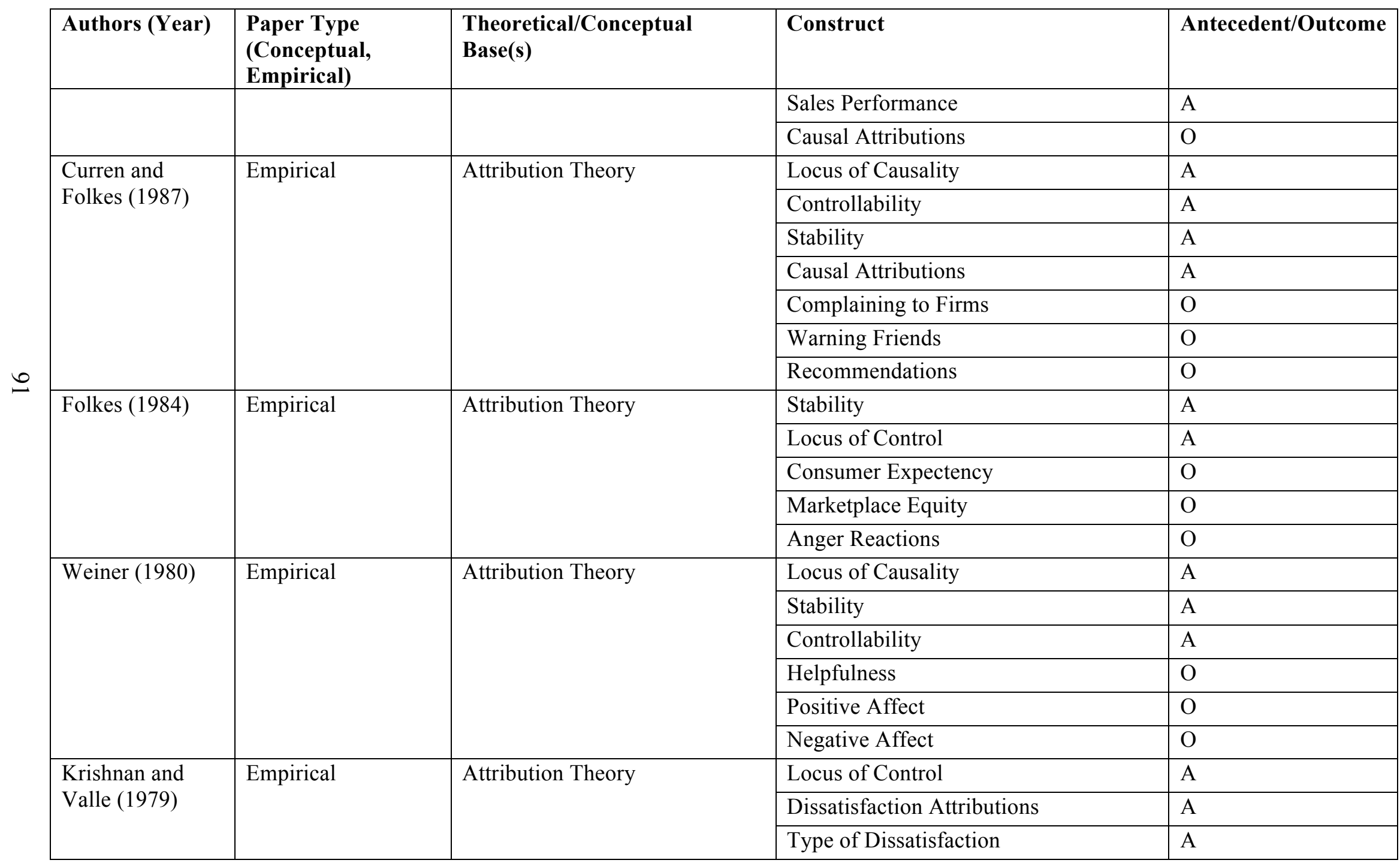




\begin{tabular}{|c|c|c|c|c|}
\hline Authors (Year) & $\begin{array}{l}\text { Paper Type } \\
\text { (Conceptual, } \\
\text { Empirical) }\end{array}$ & $\begin{array}{l}\text { Theoretical/Conceptual } \\
\text { Base(s) }\end{array}$ & Construct & Antecedent/Outcome \\
\hline & & & Consumer Demographics & $\mathrm{A}$ \\
\hline & & & Post Purchase Dissatisfaction & $\mathrm{O}$ \\
\hline \multirow{5}{*}{$\begin{array}{l}\text { Krishnan and } \\
\text { Valle (1979) }\end{array}$} & \multirow[t]{5}{*}{ Empirical } & \multirow[t]{5}{*}{ Attribution Theory } & Locus of Control & $\mathrm{A}$ \\
\hline & & & Dissatisfaction Attributions & $\mathrm{A}$ \\
\hline & & & Consumer Demographics & $\mathrm{A}$ \\
\hline & & & Complaint Behavior & $\mathrm{O}$ \\
\hline & & & Post Purchase Dissatisfaction & $\mathrm{O}$ \\
\hline \multirow{11}{*}{$\begin{array}{l}\text { Mizerski, Golden } \\
\text { and Kernan } \\
(1979)\end{array}$} & \multirow[t]{9}{*}{ Conceptual } & \multirow[t]{9}{*}{ Attribution Theory } & Person-Perception & $\mathrm{A}$ \\
\hline & & & Choice & $\mathrm{A}$ \\
\hline & & & Object-Perception & A \\
\hline & & & Distinctiveness & A \\
\hline & & & Consistency over time & $\mathrm{A}$ \\
\hline & & & Consistency over modality & $\mathrm{A}$ \\
\hline & & & Consensus & $\mathrm{A}$ \\
\hline & & & Stability & $\mathrm{A}$ \\
\hline & & & Attitude & $\mathrm{O}$ \\
\hline & \multirow[t]{2}{*}{ Empirical } & \multirow[t]{2}{*}{ Attribution Theory } & Locus of Control & $\mathrm{A}$ \\
\hline & & & Tie Strength & $\mathrm{A}$ \\
\hline
\end{tabular}




\begin{tabular}{|c|c|c|c|c|}
\hline Authors (Year) & $\begin{array}{l}\text { Paper Type } \\
\text { (Conceptual, } \\
\text { Empirical) }\end{array}$ & $\begin{array}{l}\text { Theoretical/Conceptual } \\
\text { Base(s) }\end{array}$ & Construct & Antecedent/Outcome \\
\hline $\begin{array}{l}\text { Valle and } \\
\text { Wallendorf } \\
\text { (1977) }\end{array}$ & & & Attribution & $\mathrm{O}$ \\
\hline \multirow{2}{*}{$\begin{array}{l}\text { Landon and } \\
\text { Emery (1975) }\end{array}$} & \multirow[t]{2}{*}{ Empirical } & \multirow[t]{2}{*}{ Attribution Theory } & Consumer Dissatisfaction & $\mathrm{A}$ \\
\hline & & & Complaint Action & $\mathrm{O}$ \\
\hline \multirow{5}{*}{ Kelley (1973) } & \multirow{5}{*}{ Conceptual } & \multirow{5}{*}{ Attribution Theory } & New Information & $\mathrm{A}$ \\
\hline & & & Locus of Causality & $\mathrm{A}$ \\
\hline & & & Covariance & $\mathrm{A}$ \\
\hline & & & Error & $\mathrm{A}$ \\
\hline & & & Actor & $\mathrm{A}$ \\
\hline \multirow{8}{*}{ Bem (1972) } & \multirow{8}{*}{ Conceptual } & \multirow[t]{8}{*}{ Attribution Theory } & Self-Perception & $\mathrm{A}$ \\
\hline & & & Cognitive Dissonance & $\mathrm{A}$ \\
\hline & & & Forced Compliance & $\mathrm{A}$ \\
\hline & & & Free Choice & $\mathrm{A}$ \\
\hline & & & Interpersonal Simulations & $\mathrm{A}$ \\
\hline & & & Misattribution effects & $\mathrm{O}$ \\
\hline & & & Dispositional Properties & $\mathrm{A}$ \\
\hline & & & Overjustification & $\mathrm{A}$ \\
\hline Kelley (1967) & Conceptual & Attribution Theory & Distinctiveness & $\mathrm{A}$ \\
\hline
\end{tabular}




\begin{tabular}{|c|c|c|c|c|}
\hline Authors (Year) & $\begin{array}{l}\text { Paper Type } \\
\text { (Conceptual, } \\
\text { Empirical) }\end{array}$ & $\begin{array}{l}\text { Theoretical/Conceptual } \\
\text { Base(s) }\end{array}$ & Construct & Antecedent/Outcome \\
\hline & & & Consistency over time & $\mathrm{A}$ \\
\hline & & & Concensus & $\mathrm{A}$ \\
\hline & & & Attribution & $\mathrm{O}$ \\
\hline \multirow{6}{*}{$\begin{array}{l}\text { Jones and Davis } \\
\text { (1965) }\end{array}$} & \multirow[t]{6}{*}{ Conceptual } & Human Actions & Actor & $\mathrm{A}$ \\
\hline & & Phenomenal Causality & Inference & $\mathrm{A}$ \\
\hline & & \multirow[t]{4}{*}{ Attribution Theory } & Ambiguity & $\mathrm{A}$ \\
\hline & & & Information & $\mathrm{A}$ \\
\hline & & & In/Out Role Behavior & $\mathrm{A}$ \\
\hline & & & Actions & $\mathrm{O}$ \\
\hline \multirow[t]{10}{*}{ Heider (1958) } & \multirow[t]{10}{*}{ Conceptual } & Interpersonal Relations & Perceiving & $\mathrm{A}$ \\
\hline & & \multirow[t]{9}{*}{ Attribution Theory } & Being Perceived & $\mathrm{A}$ \\
\hline & & & Analysis of Action & $\mathrm{A}$ \\
\hline & & & Desire and Pleasure & $\mathrm{A}$ \\
\hline & & & Environmental Effects & A \\
\hline & & & Sentiment & $\mathrm{A}$ \\
\hline & & & Ought and Value & $\mathrm{A}$ \\
\hline & & & Request and Command & $\mathrm{A}$ \\
\hline & & & Benefit and Harm & $\mathrm{A}$ \\
\hline & & & Reaction to other person & $\mathrm{O}$ \\
\hline
\end{tabular}




\section{APPENDIX C: EXPERIMENTS}

\section{Study 1}

\section{Manipulation 1: Offline vs. eWOM}

Scenario 1: (eWOM)

You are purchasing a t-shirt from an online retailer you have not previously

purchased from. The website has the following online reviews for the shirt:

Please read the following reviews aloud:

Reviewer 1: I just received this t-shirt and am very satisfied with the product. The fit and color are as expected and the material seems well made. I recommend buying this shirt.

Reviewer 2: This is the best t-shirt I have ever bought! I wear it all the time and it looks great!

Reviewer 3: This store has great t-shirts. Anyone considering buying this shirt should. I did and I am very satisfied with my purchase.

Scenario 2: (Offline)

You are purchasing a t-shirt from an online retailer you have not previously purchased from. Your friends provided the following reviews for the shirt:

Please read the following reviews aloud, as if you were talking to a friend: Friend 1: I just received this t-shirt and am very satisfied with the product. The fit and color are as expected and the material seems well made. I recommend buying this shirt.

Friend 2: This is the best t-shirt I have ever bought! I wear it all the time and it looks great!

Friend 3: This store has great t-shirts. Anyone considering buying this shirt should. I did and I am very satisfied with my purchase.

1. How satisfied do you expect you will be with this product?

Very unsatisfied

Very Satisfied 


\section{Manipulation 2: Satisfaction with the t-shirt}

Similar to (Despite) your friends' (the reviewers') satisfaction with the t-shirt, you are satisfied (dissatisfied) with the purchase. You found that the t-shirt exceeded (was below) expectations.

2. Given the scenario above, how would you rate your satisfaction with the t-shirt purchase?

Very dissatisfied

Very

Satisfied

2

3

4

5

6

7

3. To whom do you attribute your satisfaction to:

Retailer

Online Reviewer

Self

4. How much do you attribute your satisfaction to the following:

a. Online retailer

Not at all

$0 \quad 1$

2

3

4

Completely

b. Reviewers

Not at all

$0 \quad 1$

12

3

4

5

Completely

C. Self

Not at all

0

1

3

4

$5 \quad$ Completely

D. Random Chance

Not at all

0

$1 \quad 2$

2

3

4

$5 \quad$ Completely

5. How much of an effect does your purchase satisfaction have on your expectation to purchase from this retailer in the future?

No effect

Makes me less likely to purchase again

Makes me more likely to purchase again

6. Who recommended this product to you?

Blogs 
Positive online reviews

Negative online reviews

Friends

Opinion leaders

7. How likely are you to try another product from this website?

Not at all likely

Very

Likely

0

1

2

3

4

5

6

8. Why do you think the reviewers highly recommended the product?

9. Are there any additional sources you would consider prior to purchasing online in the future (select all that apply):

Blogs

Positive online reviews

Negative online reviews

Opinion leaders

Friends \& family

10. What sources do you commonly use prior to making a purchase:

Blogs

Positive online reviews

Negative online reviews

Opinion leaders

Friends \& family

11. Roughly how many of each source do you consider prior to making a purchase?

Blogs

Positive online reviews

Negative online reviews

Opinion leaders

Friends \& family

12. Gender: Male

Female

13. How often do you shop online?

Always Frequently

Sometimes

Never 
14. How strong would you say your technological skills are? (Using the Internet and social media platforms)

Not very strong

Very

Strong 2

3

4

5

6

7

15. Approximately how many hours per day do you spend online?

0 - $1-2$

3-4

$5-6$

7-8

9 or more

16. How old are you? 


\section{Study 2}

\section{Manipulation 1: eWOM from a Stranger vs. Friend}

Scenario 1: (eWOM, Strangers)

You are purchasing a scarf from an online retailer from whom you have not

previously purchased. The website has the following online reviews for the scarf:

Please read the following reviews aloud:

Reviewer 1: I just received this scarf and am very satisfied with the product. The scarf is well designed and well made. I recommend buying this scarf.

Reviewer 2: This is the best scarf I ever bought! I wear it all the time and it looks great!

Reviewer 3: This store has great scarves. Anyone considering buying this scarf should. I did and I am very satisfied with my purchase.

Scenario 2: (Offline)

You are purchasing a scarf from an online retailer from whom you have not previously purchased. Your friends provided the following reviews for the scarf, which you can see on the retailer's website:

Please read the following reviews aloud:

Friend 1: I just received this scarf and am very satisfied with the product. The scarf is well designed and well made. I recommend buying this scarf.

Friend 2: This is the best scarf I ever bought! I wear it all the time and it looks great!

Friend 3: This store has great scarfes. Anyone considering buying this scarf should. I did and I am very satisfied with my purchase.

1. How satisfied do you expect you will be with this product?

Very dissatisfied

Very

Satisfied

1

$2 \quad 3 \quad 4$

5

6

7

\section{Manipulation 2: Product Performance}

Your scarf arrived. Similar (Despite) to your friends' (reviewers') satisfaction with the t-shirt, you are satisfied (dissatisfied) with the purchase.

2. Given the scenario above, how would you rate your satisfaction with the scarf purchase? 
Very dissatisfied

Very

Satisfied

1

2

3

4

5

6

7

3. To whom do you attribute your level of satisfaction with the product's performance? (check all that apply)

Retailer

Friend

Self

Random Chance

4. How much do you attribute your satisfaction to the following:

a. Online retailer

Not at all

Completely

$0 \quad 1$

2

3

4

5

6

b. Online reviewers

Not at all

Completely

0

2

3

4

5

6

C. Self

Not at all

Completely

$0 \quad 1$

2

3

4

5

6

D. Random Chance

Not at all

0

1

2

3

4

$5 \quad 6$

Completely

The items below concern your impressions or opinions of the cause or causes for your level of satisfaction following the scarf's performance. (McAuley, Duncan \& Russell, 1992; reliability internal causality $=\alpha=.79$; reliability external causality $=\alpha=.82$ )

5. The cause of your level of satisfaction with the scarf:

\begin{tabular}{|l|l|l|l|l|l|l|l|l|}
\hline $\begin{array}{l}\text { Reflects an aspect of } \\
\text { yourself }\end{array}$ & 1 & 2 & 3 & 4 & 5 & 6 & 7 & $\begin{array}{l}\text { Reflects an aspect of the } \\
\text { situation }\end{array}$ \\
\hline
\end{tabular}




\begin{tabular}{|l|l|l|l|l|l|l|l|l|}
\hline Was manageable by you & 1 & 2 & 3 & 4 & 5 & 6 & 7 & $\begin{array}{l}\text { Was not manageable by } \\
\text { you }\end{array}$ \\
\hline $\begin{array}{l}\text { Was something you could } \\
\text { have regulated }\end{array}$ & 1 & 2 & 3 & 4 & 5 & 6 & 7 & $\begin{array}{l}\text { Was not something you } \\
\text { could have regulated }\end{array}$ \\
\hline Reflects on the reviewers & 1 & 2 & 3 & 4 & 5 & 6 & 7 & $\begin{array}{l}\text { Does not reflect on the } \\
\text { reviewers }\end{array}$ \\
\hline $\begin{array}{l}\text { Was something over which } \\
\text { the reviewers had control }\end{array}$ & 1 & 2 & 3 & 4 & 5 & 6 & 7 & $\begin{array}{l}\text { Was not something over } \\
\text { which the reviewers had } \\
\text { control }\end{array}$ \\
\hline $\begin{array}{l}\text { Was something over which } \\
\text { the reviewers had power }\end{array}$ & 1 & 2 & 3 & 4 & 5 & 6 & 7 & $\begin{array}{l}\text { Was not something over } \\
\text { which the reviewers had } \\
\text { power }\end{array}$ \\
\hline $\begin{array}{l}\text { Reflects on the retailer that } \\
\text { sold the scarf }\end{array}$ & 1 & 2 & 3 & 4 & 5 & 6 & 7 & $\begin{array}{l}\text { Does not reflect on the } \\
\text { retailer }\end{array}$ \\
\hline $\begin{array}{l}\text { Was something over which } \\
\text { the retailer had control }\end{array}$ & 1 & 2 & 3 & 4 & 5 & 6 & 7 & $\begin{array}{l}\text { Was not something over } \\
\text { which the retailer had } \\
\text { control }\end{array}$ \\
\hline $\begin{array}{l}\text { Was something over which } \\
\text { the retailer had power }\end{array}$ & 1 & 2 & 3 & 4 & 5 & 6 & 7 & $\begin{array}{l}\text { Was not something over } \\
\text { which the retailer had } \\
\text { power }\end{array}$ \\
\hline
\end{tabular}

6. Please rate your level of agreement with each of the statements about your intentions to engage in the following behaviors, which are related to the retailer that sold you the scarf in the scenario. (Cronin, Brady \& Hult, 2000; $\alpha=.87$ )

\begin{tabular}{|l|l|l|l|l|l|l|l|}
\hline & $\begin{array}{l}\text { Strongly } \\
\text { Disagree }\end{array}$ & & & & & & $\begin{array}{l}\text { Strongly } \\
\text { Agree }\end{array}$ \\
\hline $\begin{array}{l}\text { I would say positive things } \\
\text { about the retailer }\end{array}$ & 1 & 2 & 3 & 4 & 5 & 6 & 7 \\
\hline $\begin{array}{l}\text { I would recommend the } \\
\text { retailer to others }\end{array}$ & 1 & 2 & 3 & 4 & 5 & 6 & 7 \\
\hline $\begin{array}{l}\text { I would suggest the retailer to } \\
\text { someone who sought my } \\
\text { advice }\end{array}$ & 1 & 2 & 3 & 4 & 5 & 6 & 7 \\
\hline $\begin{array}{l}\text { I would repurchase from this } \\
\text { retailer }\end{array}$ & 1 & 2 & 3 & 4 & 5 & 6 & 7 \\
\hline $\begin{array}{l}\text { I would spend more of my } \\
\text { money on things from this } \\
\text { retailer }\end{array}$ & 1 & 2 & 3 & 4 & 5 & 6 & 7 \\
\hline $\begin{array}{l}\text { I would pay a price premium } \\
\text { to buy from this retailer again }\end{array}$ & 1 & 2 & 3 & 4 & 5 & 6 & 7 \\
\hline
\end{tabular}

7. Who recommended this product to you?

Blogs

Positive online reviews

Negative online reviews 
Friends

Opinion leaders

8. How likely are you to try another product that was recommended by these reviewers?

Not at all likely

Likely

$\begin{array}{llllll}0 & 1 & 2 & 3 & 4 & 5\end{array}$

6

9. Why do you think the reviewers highly recommended the product?

10. Are there any additional sources you would consider prior to purchasing online in the future (select all that apply):

Blogs

Positive online reviews

Negative online reviews

Opinion leaders

Friends \& family

11. What sources do you commonly use prior to making a purchase:

Blogs

Positive online reviews

Negative online reviews

Opinion leaders

Friends \& family

12. Roughly how many of each source do you consider prior to making a purchase?

Blogs

Positive online reviews

Negative online reviews

Opinion leaders

Friends \& family

13. Gender: Male Female

14. How often do you shop online?

Always Frequently

Sometimes Never 
15. How strong would you say your technological skills are? (Using the Internet and social media platforms)

Not very strong

Very

Strong

2

34

5

6

7

16. Approximately how many hours per day do you spend online?

$1-2$

$3-4$

$5-6$

$7-8$

9 or more

17. How old are you? 


\section{Study 3}

\section{Manipulation 1: eWOM from a Friend vs. Incentivized Friend}

Scenario 1: (eWOM, Friend)

You are purchasing a scarf from an online retailer from whom you have not

previously purchased. Your friends provided the following reviews for the scarf,

which you can see on the retailer's website:

Please read the following reviews aloud:

Friend 1: I just received this scarf and am very satisfied with the product. The scarf is well designed and well made. I recommend buying this scarf.

Friend 2: This is the best scarf I ever bought! I wear it all the time and it looks great!

Friend 3: This store has great scarfes. Anyone considering buying this scarf should. I did and I am very satisfied with my purchase.

Scenario 1: (eWOM, Friend, Incentivized)

You are purchasing a scarf from an online retailer from whom you have not previously purchased. Your friends provided the following reviews for the scarf, which you can see on the retailer's website:

The reviews have a note above them from the retailer, which says "(Disclosure: The reviewers received a $\$ 10$ store credit in exchange for their reviews)"

Please read the following reviews aloud:

Friend 1: I just received this scarf and am very satisfied with the product. The scarf is well designed and well made. I recommend buying this scarf.

Friend 2: This is the best scarf I ever bought! I wear it all the time and it looks great!

Friend 3: This store has great scarfes. Anyone considering buying this scarf should. I did and I am very satisfied with my purchase.

1. How satisfied do you expect you will be with this product?

Very dissatisfied Satisfied

$\begin{array}{lllllll}1 & 2 & 3 & 4 & 5 & 6 & 7\end{array}$

\section{Manipulation 2: Product Performance}

Your scarf arrived. Similar (Despite) to your friends' (reviewers') satisfaction with the t-shirt, you are satisfied (dissatisfied) with the purchase. 
2. Given the scenario above, how would you rate your satisfaction with the scarf purchase?

Very dissatisfied

Very

Satisfied

2

3

4

5

6

7

3. To whom do you attribute your level of satisfaction with the product's performance? (check all that apply)

Retailer

Friend

Self

Random Chance

4. How much do you attribute your satisfaction to the following:

a. Online retailer

Not at all

0

1

2

3

4

5

Completely

b. Online reviewers

Not at all

0

12

3

4

5

Completely

C. Self

Not at all

0

12

3

4

Completely

D. Random Chance

Not at all

0

1

2

3

4

Completely

5

6

The items below concern your impressions or opinions of the cause or causes for your level of satisfaction following the scarf's performance. (McAuley, Duncan \& Russell, 1992; reliability internal causality $=\alpha=.79$; reliability external causality $=\alpha=.82$ )

7. The cause of your level of satisfaction with the scarf:

\begin{tabular}{|l|l|l|l|l|l|l|l|l|}
\hline $\begin{array}{l}\text { Reflects an aspect of } \\
\text { yourself }\end{array}$ & 1 & 2 & 3 & 4 & 5 & 6 & 7 & $\begin{array}{l}\text { Reflects an aspect of the } \\
\text { situation }\end{array}$ \\
\hline Was manageable by you & 1 & 2 & 3 & 4 & 5 & 6 & 7 & $\begin{array}{l}\text { Was not manageable by } \\
\text { you }\end{array}$ \\
\hline $\begin{array}{l}\text { Was something you could } \\
\text { have regulated }\end{array}$ & 1 & 2 & 3 & 4 & 5 & 6 & 7 & $\begin{array}{l}\text { Was not something you } \\
\text { could have regulated }\end{array}$ \\
\hline Reflects on the reviewers & 1 & 2 & 3 & 4 & 5 & 6 & 7 & $\begin{array}{l}\text { Does not reflect on the } \\
\text { reviewers }\end{array}$ \\
\hline
\end{tabular}




\begin{tabular}{|l|l|l|l|l|l|l|l|l|}
\hline $\begin{array}{l}\text { Was something over which } \\
\text { the reviewers had control }\end{array}$ & 1 & 2 & 3 & 4 & 5 & 6 & 7 & $\begin{array}{l}\text { Was not something over } \\
\text { which the reviewers had } \\
\text { control }\end{array}$ \\
\hline $\begin{array}{l}\text { Was something over which } \\
\text { the reviewers had power }\end{array}$ & 1 & 2 & 3 & 4 & 5 & 6 & 7 & $\begin{array}{l}\text { Was not something over } \\
\text { which the reviewers had } \\
\text { power }\end{array}$ \\
\hline $\begin{array}{l}\text { Reflects on the retailer that } \\
\text { sold the scarf }\end{array}$ & 1 & 2 & 3 & 4 & 5 & 6 & 7 & $\begin{array}{l}\text { Does not reflect on the } \\
\text { retailer }\end{array}$ \\
\hline $\begin{array}{l}\text { Was something over which } \\
\text { the retailer had control }\end{array}$ & 1 & 2 & 3 & 4 & 5 & 6 & 7 & $\begin{array}{l}\text { Was not something over } \\
\text { which the retailer had } \\
\text { control }\end{array}$ \\
\hline $\begin{array}{l}\text { Was something over which } \\
\text { the retailer had power }\end{array}$ & 1 & 2 & 3 & 4 & 5 & 6 & 7 & $\begin{array}{l}\text { Was not something over } \\
\text { which the retailer had } \\
\text { power }\end{array}$ \\
\hline
\end{tabular}

8. Please rate your level of agreement with each of the statements about your intentions to engage in the following behaviors, which are related to the retailer that sold you the scarf in the scenario. (Cronin, Brady \& Hult, 2000; $\alpha=.87$ )

\begin{tabular}{|l|l|l|l|l|l|l|l|}
\hline & $\begin{array}{l}\text { Strongly } \\
\text { Disagree }\end{array}$ & & & & & & $\begin{array}{l}\text { Strongly } \\
\text { Agree }\end{array}$ \\
\hline $\begin{array}{l}\text { I would say positive things } \\
\text { about the retailer }\end{array}$ & 1 & 2 & 3 & 4 & 5 & 6 & 7 \\
\hline $\begin{array}{l}\text { I would recommend the } \\
\text { retailer to others }\end{array}$ & 1 & 2 & 3 & 4 & 5 & 6 & 7 \\
\hline $\begin{array}{l}\text { I would suggest the retailer to } \\
\text { someone who sought my } \\
\text { advice }\end{array}$ & 1 & 2 & 3 & 4 & 5 & 6 & 7 \\
\hline $\begin{array}{l}\text { I would repurchase from this } \\
\text { retailer }\end{array}$ & 1 & 2 & 3 & 4 & 5 & 6 & 7 \\
\hline $\begin{array}{l}\text { I would spend more of my } \\
\text { money on things from this } \\
\text { retailer }\end{array}$ & 1 & 2 & 3 & 4 & 5 & 6 & 7 \\
\hline $\begin{array}{l}\text { I would pay a price premium } \\
\text { to buy from this retailer again }\end{array}$ & 1 & 2 & 3 & 4 & 5 & 6 & 7 \\
\hline
\end{tabular}

7. Who recommended this product to you?

Blogs

Positive online reviews from friends

Negative online reviews from friend

Opinion leaders

8. Were the reviewers compensated in any way for providing the reviews?

Yes

No 
If yes, how were they compensated?

9. How likely are you to try another product that was recommended by these reviewers?

Not at all likely

Likely

$\begin{array}{llllll}0 & 1 & 2 & 3 & 4 & 5\end{array}$

6

10. Why do you think the reviewers highly recommended the product?

11. Are there any additional sources you would consider prior to purchasing online in the future (select all that apply):

Blogs

Positive online reviews

Negative online reviews

Opinion leaders

Friends \& family

12. What sources do you commonly use prior to making a purchase:

Blogs

Positive online reviews

Negative online reviews

Opinion leaders

Friends \& family

13. Roughly how many of each source do you consider prior to making a purchase?

Blogs

Positive online reviews

Negative online reviews

Opinion leaders

Friends \& family

14. Gender: Male Female

15. How often do you shop online?

Always Frequently

Sometimes

Never 
16. How strong would you say your technological skills are? (Using the Internet and social media platforms)

Not very strong

Very

Strong

2

$3 \quad 4$

5

6

7

17. Approximately how many hours per day do you spend online?

$1-2$

$3-4$

$5-6$

$7-8$

9 or more

18. How old are you? 


\section{BIBLIOGRAPHY}

Algesheimer, R., Dholakia, U. M., \& Herrmann, A. (2005). The social influence of brand community: Evidence from European car clubs. Journal of marketing, 69(3), 19-34.

Ahluwalia, R., Burnkrant, R. E., \& Unnava, H. R. (2000). Consumer response to negative publicity: The moderating role of commitment. Journal of marketing research, 37(2), 203-214.

Anderson, M., \& Magruder, J. (2012). Learning from the crowd: Regression discontinuity estimates of the effects of an online review database. The Economic Journal, 122(563), 957-989.

Arkin, R. M., Appelman, A. J., \& Burger, J. M. (1980). Social anxiety, selfpresentation, and the self-serving bias in causal attribution. Journal of personality and social psychology, 38(1), 23.

Armstrong, A., \& Hagel III, J. (1995). Real profits from virtual communities. The McKinsey Quarterly, (3), 127-128.

Arndt, J. (1967). Role of product-related conversations in the diffusion of a new product. Journal of marketing Research, 291-295.

Aron, A., Aron, E. N., Tudor, M., \& Nelson, G. (1991). Close relationships as including other in the self. Journal of personality and social psychology, 60(2), 241.

Asch, S. E. (1955). Opinions and social pressure. Readings about the Social Animal, 193, 17-26.

Ball, A. D., \& Tasaki, L. H. (1992). The role and measurement of attachment in consumer behavior. Journal of consumer psychology, 1(2), 155-172.

Barnett, H. G. (1953). Innovation: the basis of cultural change.

Bass, F. M. (1969). A new product growth for model consumer durables. Management science, 15(5), 215-227.

Bayus, B. L. (1985). Word of mouth: The indirect effects of marketing efforts. Journal of Advertising Research, 25(3), 31-39.

Bearden, W. O., Netemeyer, R. G., \& Teel, J. E. (1989). Measurement of consumer susceptibility to interpersonal influence. Journal of Consumer Research, 15(4), 473481. 
Belk, R. W. (1988). Possessions and the extended self. Journal of consumer research, 15(2), 139-168.

Belk, R. W. (2013). Extended self in a digital world. Journal of Consumer Research, 40(3), 477-500.

Bem, D. J. (1972). Self-perception theory. Advances in Experimental Social Psychology, 6, 1-62.

Berger, J. (2014). Word of mouth and interpersonal communication: A review and directions for future research. Journal of Consumer Psychology, 24(4), 586-607.

Berger, J., \& Heath, C. (2007). Where consumers diverge from others: Identity signaling and product domains. Journal of Consumer Research, 34(2), 121-134.

Berger, J., \& Heath, C. (2008). Who drives divergence? Identity signaling, outgroup dissimilarity, and the abandonment of cultural tastes. Journal of personality and social psychology, 95(3), 593.

Berger, J., \& Iyengar, R. (2013). Communication channels and word of mouth: How the medium shapes the message. Journal of Consumer Research, 40(3), 567-579.

Berger, J., \& Milkman, K. L. (2012). What makes online content viral? Journal of marketing research, 49(2), 192-205.

Berger, J., \& Schwartz, E. M. (2011). What drives immediate and ongoing word of mouth?. Journal of Marketing Research, 48(5), 869-880.

Berndt, T. J., \& Keefe, K. (1995). Friends' influence on adolescents' adjustment to school. Child development, 66(5), 1312-1329.

Berry, L. L. (1983). Relationship marketing. American Marketing Association.

Bhattacharya, C. B., \& Sen, S. (2003). Consumer-company identification: A framework for understanding consumers' relationships with companies. Journal of marketing, 67(2), 76-88.

Bickart, B., \& Schindler, R. M. (2001). Internet forums as influential sources of consumer information. Journal of interactive marketing, 15(3), 31-40.

Bitner, M. J. (1990). Evaluating service encounters: the effects of physical surroundings and employee responses. the Journal of Marketing, 69-82.

Blackston, M. (1992). Observations: building brand equity by managing the brand's relationships. Journal of advertising research, 32(3), 79-83. 
Blazevic, V., Hammedi, W., Garnefeld, I., Rust, R. T., Keiningham, T., Andreassen, T. W. \& Carl, W. (2013). Beyond traditional word-of-mouth: an expanded model of customer-driven influence. Journal of Service Management, 24(3), 294-313.

Breakenridge, D. (2001). Cyberbranding: brand building in the digital economy. Prentice Hall PTR.

Breazeale, M. (2009). An Assessment of Electronic Word-of-Mouth Research. International Journal of Market Research, 51(3), 297-318.

BrightLocal. (2014). Local Consumer Review Survey 2014.

Brown, L. A. (1981). Innovation diffusion; a new perspective. Methuen.

Brown, J., Broderick, A. J., \& Lee, N. (2007). Word of mouth communication within online communities: Conceptualizing the online social network. Journal of interactive marketing, 21(3), 2-20.

Brown, J. J., \& Reingen, P. H. (1987). Social ties and word-of-mouth referral behavior. Journal of Consumer Research, 14(3), 350-362.

Burger, J. M., Messian, N., Patel, S., del Prado, A., \& Anderson, C. (2004). What a coincidence! The effects of incidental similarity on compliance. Personality and Social Psychology Bulletin, 30(1), 35-43.

Burke, P. J., \& Stets, J. E. (2009). Identity theory. Oxford University Press.

Burnkrant, R. E., \& Cousineau, A. (1975). Informational and normative social influence in buyer behavior. Journal of Consumer research, 2(3), 206-215.

Burt, R. S. (2009). Structural holes: The social structure of competition. Harvard university press.

Cabral, L., \& Li, L. (2015). A dollar for your thoughts: Feedback-conditional rebates on eBay. Management Science, 61(9), 2052-2063.

Campbell, W. K., \& Sedikides, C. (1999). Self-threat magnifies the self-serving bias: A meta-analytic integration. Review of General Psychology, 3(1), 23.

Celsi, R. L., Rose, R. L., \& Leigh, T. W. (1993). An exploration of high-risk leisure consumption through skydiving. Journal of consumer research, 20(1), 1-23.

Chaplin, L. N., \& Lowrey, T. M. (2010). The development of consumer-based consumption constellations in children. Journal of Consumer Research, 36(5), 757777. 
Chatterjee P. (2001). Online reviews: do consumers use them? in $N A$-Advances in Consumer Research Volume 28, eds. Mary C. Gilly and Joan Meyers-Levy, Valdosta, GA: Association for Consumer Research, 129-133.

Chaudhuri, A., \& Holbrook, M. B. (2001). The chain of effects from brand trust and brand affect to brand performance: the role of brand loyalty. Journal of marketing, 65(2), 81-93.

Cheema, A., \& Kaikati, A. M. (2010). The effect of need for uniqueness on word of mouth. Journal of Marketing Research, 47(3), 553-563.

Chen, Z., \& Lurie, N. H. (2013). Temporal contiguity and negativity bias in the impact of online word of mouth. Journal of Marketing Research, 50(4), 463-476.

Cheung, C. M., \& Lee, M. K. (2012). What drives consumers to spread electronic word of mouth in online consumer-opinion platforms. Decision Support Systems, 53(1), 218-225.

Chevalier, J. A., \& Mayzlin, D. (2006). The effect of word of mouth on sales: Online book reviews. Journal of Marketing Research, 43(3), 345-354.

Chintagunta, P. K., Gopinath, S., \& Venkataraman, S. (2010). The effects of online user reviews on movie box office performance: Accounting for sequential rollout and aggregation across local markets. Marketing Science, 29(5), 944-957.

Correa, T., Hinsley, A. W., \& De Zuniga, H. G. (2010). Who interacts on the Web?: The intersection of users' personality and social media use. Computers in Human Behavior, 26(2), 247-253.

Cronin, J. J., Brady, M. K., \& Hult, G. T. M. (2000). Assessing the effects of quality, value, and customer satisfaction on consumer behavioral intentions in service environments. Journal of retailing, 76(2), 193-218.

Cropanzano, R., \& Mitchell, M. S. (2005). Social exchange theory: An interdisciplinary review. Journal of management, 31(6), 874-900.

Crosby, L. A., Evans, K. R., \& Cowles, D. (1990). Relationship quality in services selling: an interpersonal influence perspective. The journal of marketing, 68-81.

Crosby, L. A., \& Stephens, N. (1987). Effects of relationship marketing on satisfaction, retention, and prices in the life insurance industry. Journal of marketing research, 404-411.

Curren, M. T., \& Folkes, V. S. (1987). Attributional influences on consumers' desires to communicate about products. Psychology and Marketing, 4(1), 31.

Das, S., \& Kramer, A. (2013). Self-censorship on Facebook. In Proceedings of ICWSM, 2013, 120-127. 
De Angelis, M., Bonezzi, A., Peluso, A. M., Rucker, D., \& Costabile, M. (2011). On braggarts and gossips: Why consumers generate positive but transmit negative word of mouth. NA-Advances in Consumer Research Volume 39.

Dellarocas, C. and Narayan, R. (2006). A statistical measure of a population's propensity to engage in post-purchase online word-of-mouth. Statistical Science, 21(2), 277-285.

Dellarocas, C., Zhang, X. M., \& Awad, N. F. (2007). Exploring the value of online product reviews in forecasting sales: The case of motion pictures. Journal of Interactive Marketing, 21(4), 23-45.

Dellarocas, C., Gao, G., \& Narayan, R. (2010). Are consumers more likely to contribute online reviews for hit or niche products? Journal of Management Information Systems, 27(2), 127-158.

Dichter, E. (1966). \{How word-of-mouth advertising works\}. Harvard Business Review, 44(6), 147-160.

Duan, W., Gu, B., \& Whinston, A. B. (2008). Do online reviews matter?-An empirical investigation of panel data. Decision Support Systems, 45(4), 1007-1016.

Duhan, D. F., Johnson, S. D., Wilcox, J. B., \& Harrell, G. D. (1997). Influences on consumer use of word-of-mouth recommendation sources. Journal of the Academy of Marketing Science, 25(4), 283-295.

Dunn, L., \& Dahl, D. W. (2012). Self-threat and product failure: how internal attributions of blame affect consumer complaining behavior. Journal of Marketing Research, 49(5), 670-681.

Dutton, J. E., Dukerich, J. M., \& Harquail, C. V. (1994). Organizational images and member identification. Administrative science quarterly, 239-263.

East, R., Hammond, K., \& Lomax, W. (2008). Measuring the impact of positive and negative word of mouth on brand purchase probability. International journal of research in marketing, 25(3), 215-224.

Easterbrook, M. J., \& Vignoles, V. L. (2015). When friendship formation goes down the toilet: Design features of shared accommodation influence interpersonal bonds and well-being. British Journal of Social Psychology, 54(1), 125-139.

Ebeid, A. Y., \& Gadelrab, H. F. (2014). A Structural Equation Modeling Approach to Investigate Negative Word of Mouth Impact on Customer-Based Brand Equity: Does Attribution Matter?. International Journal of Business and Social Research, 4(9), 113. 
Einwiller, S. A., Fedorikhin, A., Johnson, A. R., \& Kamins, M. A. (2006). Enough is enough! When identification no longer prevents negative corporate associations. Journal of the Academy of Marketing Science, 34(2), 185-194.

Einwiller, S. A., \& Kamins, M. A. (2008). Rumor has it: the moderating effect of identification on rumor impact and the effectiveness of rumor refutation1. Journal of Applied Social Psychology, 38(9), 2248-2272.

Mlicki, P., \& Ellemers, N. (1996). Being different or being better? National stereotypes and identifications of Polish and Dutch students.

Ellison, N. B. (2007). Social network sites: Definition, history, and scholarship. Journal of Computer-Mediated Communication, 13(1), 210-230.

Engel, J. F., Kegerreis, R. J., \& Blackwell, R. D. (1969). Word-of-mouth communication by the innovator. The Journal of Marketing, 15-19.

Escalas, J. E., \& Bettman, J. R. (2003). 13 Using narratives to discern self-identity related consumer goals and motivations. The why of consumption: Contemporary perspectives on consumer motives, goals, and desires, 1, 237.

Evanschitzky, H., Brock, C., \& Blut, M. (2011). Will you tolerate this? The impact of affective commitment on complaint intention and postrecovery behavior. Journal of Service Research.

Federal Trade Commission. (2009). Guides Concerning the Use of Endorsements and Testimonials in Advertising. 16 CFR Part 255.

Feick, L., \& Higie, R. A. (1992). The effects of preference heterogeneity and source characteristics on ad processing and judgements about endorsers. Journal of Advertising, 21(2), 9-24.

Feick, L. F., \& Price, L. L. (1987). The market maven: A diffuser of marketplace information. The Journal of Marketing, 83-97.

Festinger, L. (1954). A theory of social comparison processes. Human relations, 7(2), 117-140.

Floh, A., Koller, M., \& Zauner, A. (2013). Taking a deeper look at online reviews: The asymmetric effect of valence intensity on shopping behaviour. Journal of Marketing Management, 29(5-6), 646-670.

Floyd, K., Freling, R., Alhoqail, S., Cho, H. Y., \& Freling, T. (2014). How online product reviews affect retail sales: A meta-analysis. Journal of Retailing, 90(2), 217232. 
Folkes, V. S. (1984). Consumer reactions to product failure: An attributional approach. Journal of Consumer Research, 10(4), 398-409.

Folkes, V. S. (1988). Recent attribution research in consumer behavior: A review and new directions. Journal of Consumer Research, 14(4), 548-565.

Folkes, V. S., \& Kotsos, B. (1986). Buyers' and sellers' explanations for product failure: Who done it?. The Journal of Marketing, 74-80.

Forman, C., Ghose, A., Wiesenfeld, B. (2008). Examining the relationship between reviews and sales: The role of reviewer identity disclosure in electronic markets. Information Systems Research, 19(3): 291-313.

Fournier, S. (1998). Consumers and their brands: Developing relationship theory in consumer research. Journal of consumer research, 24(4), 343-373.

Frank, K. A., Muller, C., \& Mueller, A. S. (2013). The Embeddedness of Adolescent Friendship Nominations: The Formation of Social Capital in Emergent Network Structures 1. American Journal of Sociology, 119(1), 216-253.

Friedkin, N. (1980). A test of structural features of Granovetter's strength of weak ties theory. Social networks, 2(4), 411-422.

Fretwell, Lisa, Jon Stine, Hiten Sethi, \& Andy Noronha. (2013). Catch and Keep' Digital Shoppers: How To Deliver Retail Their Way. Cisco.

Fuchs, C., Schreier, M., \& van Osselaer, S. M. (2015). The handmade effect: What's love got to do with it? Journal of Marketing, 79(2), 98-110.

Gilbert, E., \& Karahalios, K. (2009, April). Predicting tie strength with social media. In Proceedings of the SIGCHI conference on human factors in computing systems (pp. 211-220). ACM.

Gilly, M. C. (1987). Post-complaint processes: from organizational response to repurchase behavior. Journal of Consumer Affairs, 21(2), 293-213.

Goldner, F. H. (1982). Pronoia. Social Problems, 30(1), 82-91.

Goldsmith, R. E., \& Horowitz, D. (2006). Measuring motivations for online opinion seeking. Journal of interactive advertising, 6(2), 2-14.

Granovetter, M. S. (1973). The strength of weak ties. American journal of sociology, $78(6), 1360-1380$.

Grégoire, Y., \& Fisher, R. J. (2008). Customer betrayal and retaliation: when your best customers become your worst enemies. Journal of the Academy of Marketing Science, $36(2), 247-261$. 
Grégoire, Y., Tripp, T. M., \& Legoux, R. (2009). When customer love turns into lasting hate: the effects of relationship strength and time on customer revenge and avoidance. Journal of Marketing, 73(6), 18-32.

Grewal, D., Roggeveen, A. L., \& Tsiros, M. (2008). The effect of compensation on repurchase intentions in service recovery. Journal of Retailing, 84(4), 424-434.

Gruen, T. W., Osmonbekov, T., \& Czaplewski, A. J. (2006). eWOM: The impact of customer-to-customer online know-how exchange on customer value and loyalty. Journal of Business research, 59(4), 449-456.

Hagel, J., \& Armstrong, A. G. (1997). Net gain. Harvard Business School Press, Boston.

Haywood, K. M. (1989). Managing word of mouth communications. Journal of Services Marketing, 3(2), 55-67.

He, S. X., \& Bond, S. D. (2015). Why is the crowd divided? Attribution for dispersion in online word of mouth. Journal of Consumer Research, 41(6), 1509-1527.

Heider, F. (1958). The Psychology of Interpersonal Relations. New York: Wiley.

Hennig-Thurau, T., Gwinner, K. P., Walsh, G., \& Gremler, D. D. (2004). Electronic word-of-mouth via consumer-opinion platforms: What motivates consumers to articulate themselves on the Internet?. Journal of Interactive Marketing, 18(1), 38-52.

Hong, S. Y., \& Yang, S. U. (2009). Effects of reputation, relational satisfaction, and customer-company identification on positive word-of-mouth intentions. Journal of Public Relations Research, 21(4), 381-403.

Iyengar, R., Van den Bulte, C., \& Valente, T. W. (2011). Opinion leadership and social contagion in new product diffusion. Marketing Science, 30(2), 195-212.

Jetten, J., Spears, R., \& Manstead, A. S. (1996). Intergroup norms and intergroup discrimination: distinctive self-categorization and social identity effects. Journal of personality and social psychology, 71(6), 1222.

Jones, E. E., \& Davis, K. E. (1965). From acts to dispositions the attribution process in person perception. Advances in Experimental Social Psychology, 2, 219-266.

Jones, S. (2013). How technology has increased our access to information and answers- Not all of them right. MediaPost.

Katz, E., \& Lazarsfeld, P. F. (1965). Personal Influence: The Part Played by People in the Flow of Mass Communications. A Foreword by Elmo Roper. Free Press. 
Keh, H. T., \& Xie, Y. (2009). Corporate reputation and customer behavioral intentions: The roles of trust, identification and commitment. Industrial Marketing Management, 38(7), 732-742.

Kelley, H. H. (1967). Attribution theory in social psychology. In Nebraska symposium on motivation. University of Nebraska Press.

Kelman, H. C. (1961). Processes of opinion change. Public opinion quarterly, 25(1), $57-78$.

Kim, C. K., Han, D., \& Park, S. B. (2001). The effect of brand personality and brand identification on brand loyalty: Applying the theory of social identification. Japanese Psychological Research, 43(4), 195-206.

King, R. A., Racherla, P., \& Bush, V. D. (2014). What we know and don't know about online word-of-mouth: A review and synthesis of the literature. Journal of Interactive Marketing, 28(3), 167-183.

Kleine, S. S., Kleine, R. E., \& Allen, C. T. (1995). How is a possession "me" or "not me"? Characterizing types and an antecedent of material possession attachment. Journal of Consumer Research, 22(3), 327-343.

Kleine, R. E., Kleine, S. S., \& Kernan, J. B. (1993). Mundane consumption and the self: A social-identity perspective. Journal of consumer psychology, 2(3), 209-235.

Kollock, P. (1994). The emergence of exchange structures: An experimental study of uncertainty, commitment, and trust. American Journal of sociology, 313-345.

Koo, D. M. (2015). The strength of no tie relationship in an online recommendation: Focused on interactional effects of valence, tie strength, and type of service. European Journal of Marketing, 49(7/8), 1163-1183.

Kratzer, J., \& Lettl, C. (2009). Distinctive roles of lead users and opinion leaders in the social networks of schoolchildren. Journal of Consumer Research, 36(4), 646-659.

Krishnan, S., \& Valle, V. A. (1979). Dissatisfaction attributions and consumer complaint behavior. NA-Advances in Consumer Research Volume 06.

Kuenzel, S., \& Vaux Halliday, S. (2008). Investigating antecedents and consequences of brand identification. Journal of Product \& Brand Management, 17(5), 293-304.

Kusumasondjaja, S., Shanka, T., \& Marchegiani, C. (2012). Credibility of online reviews and initial trust: The roles of reviewer's identity and review valence. Journal of Vacation Marketing, 18(3), 185-195.

Landon, L. E., \& Emery, D. R. (1975). Causal Attribution of Consumer Dissatisfaction as a Predictor of Complaint Action: A Preliminary Report. In conference of the Association for Consumer Research, Chicago. 
Lata, K., \& Singh, N. S. K. (2016). Presentation of profile: social identity formation by Facebook users. International Journal of Management and Social Sciences (IJMSS), 5(2), 61-66.

Leskovec, J., Adamic, L. A., \& Huberman, B. A. (2007). The dynamics of viral marketing. ACM Transactions on the Web (TWEB), 1(1), 5.

Lin, N., Dayton, P. W., \& Greenwald, P. (1978). Analyzing the instrumental use of relations in the context of social structure. Sociological Methods \& Research, 7(2), 149-166.

Lin, N., Ensel, W. M., \& Vaughn, J. C. (1981). Social resources and strength of ties: Structural factors in occupational status attainment. American sociological review, 393-405.

Lisjak, M., Lee, A. Y., \& Gardner, W. L. (2012). When a threat to the brand is a threat to the self the importance of brand identification and implicit self-esteem in predicting defensiveness. Personality and Social Psychology Bulletin, 38(9), 1120-1132.

Littlefield, J., \& Ozanne, J. L. (2011). Socialization into consumer culture: Hunters learning to be men. Consumption Markets \& Culture, 14(4), 333-360.

Liu, Y. (2006). Word of mouth for movies: Its dynamics and impact on box office revenue. Journal of marketing, 70(3), 74-89.

Livingstone, S. (2008). Taking risky opportunities in youthful content creation: teenagers' use of social networking sites for intimacy, privacy and self-expression. New media \& society, 10(3), 393-411.

Ludwig, S., De Ruyter, K., Friedman, M., Brüggen, E. C., Wetzels, M., \& Pfann, G. (2013). More than words: The influence of affective content and linguistic style matches in online reviews on conversion rates. Journal of Marketing, 77(1), 87-103.

Machleit, K. A., \& Mantel, S. P. (2001). Emotional response and shopping satisfaction: Moderating effects of shopper attributions. Journal of Business Research, 54(2), 97-106.

Mahajan, V., Muller, E., \& Wind, Y. (Eds.). (2000). New-product diffusion models (Vol. 11). Springer Science \& Business Media.

Marsden, P. V., \& Campbell, K. E. (1984, 1990). Measuring tie strength. Social forces, 63(2), 482-501.

Marsden, P., \& Chaney, P. (2012). The social commerce handbook: 20 secrets for turning social media into social sales. McGraw Hill Professional. 
Martin, W. C. (2015). Independent versus incentivized word-of-mouth: Effects on listeners. Academy of Marketing Studies Journal, 19(1), 1.

Maxwell, J. C., \& Dornan, J. (1997). Becoming a person of influence: How to positively impact the lives of others. Thomas Nelson Inc.

McAuley, E., Duncan, T. E., \& Russell, D. W. (1992). Measuring causal attributions: The revised causal dimension scale (CDSII). Personality and Social Psychology Bulletin, 18(5), 566-573.

McClelland, D. C. (1951). Measuring motivation in phantasy: the achievement motive.

McCullough, M. E., \& Witvliet, C. V. (2002). The psychology of forgiveness. Handbook of Positive Psychology, 2, 446-455.

McEwen, W. J. (2005). Married to the brand: Why consumers bond with some brands for life. Simon and Schuster.

Mehra, A., Kilduff, M., \& Brass, D. J. (1998). At the margins: A distinctiveness approach to the social identity and social networks of underrepresented groups. Academy of Management Journal, 41(4), 441-452.

Miller, D. T., \& Ross, M. (1975). Self-serving biases in the attribution of causality: Fact or fiction?. Psychological bulletin, 82(2), 213.

Minnema, A., Bijmolt, T. H., Gensler, S., \& Wiesel, T. (2016). To Keep or Not to Keep: Effects of Online Customer Reviews on Product Returns. Journal of Retailing, 92(3), 253-267.

Mizerski, R. W., Golden, L. L., \& Kernan, J. B. (1979). The attribution process in consumer decision making. Journal of Consumer Research, 6(2), 123-140.

Moon, Y. (2003). Don't blame the computer: When self-disclosure moderates the selfserving bias. Journal of Consumer Psychology, 13(1), 125-137.

Moorman, Christine (2014). CMO Survey Report: Highlights and Insights. August.

Morgan, R. M., \& Hunt, S. D. (1994). The commitment-trust theory of relationship marketing. The journal of marketing, 20-38.

Muller, T. E., Tse, D. K., \& Venkatasubramaniam, R. (1991). Post-consumption emotions: exploring their emergence and determinants. Journal of Consumer Satisfaction, Dissatisfaction and Complaining Behavior, 4(1991), 13-20.

Muniz, A. M., \& O'Guinn, T. C. (2001). Brand community. Journal of Consumer Research, 27(4), 412-432. 
Norton, J. A., \& Bass, F. M. (1987). A diffusion theory model of adoption and substitution for successive generations of high-technology products. Management science, 33(9), 1069-1086.

Nyquist, J. D., Bitner, M. J., \& Booms, B. H. (1985). Identifying communication difficulties in the service encounter: a critical incident approach. The Service Encounter, 195-212.

Oliver, R. L., \& DeSarbo, W. S. (1988). Response determinants in satisfaction judgments. Journal of Consumer Research, 14(4), 495-507.

Ortiz, M. H., \& Harrison, M. P. (2011). Crazy little thing called love: A consumerretailer relationship. Journal of Marketing Development and Competitiveness, 5(3), 68.

Osenton, T. (2002). Customer share marketing: how the world's great marketers unlock profits from customer loyalty. FT Press.

Oyserman, D. (2009). Identity-based motivation and consumer behavior. Journal of Consumer Psychology, 19(3), 276-279.

Packard, G. M., \& Berger, J. A. (2015). Following the Blind: How Expertise and Endorsement Style Impact Word of Mouth Persuasion. Available at SSRN 2615023.

Palmatier, R. W., Dant, R. P., Grewal, D., \& Evans, K. R. (2006). Factors influencing the effectiveness of relationship marketing: a meta-analysis. Journal of marketing, 70(4), 136-153.

Park, C., \& Lee, T. M. (2009). Information direction, website reputation and eWOM effect: A moderating role of product type. Journal of Business Research, 62(1), 61-67.

Pavlou, P., \& Wang, S. (2015). How do monetary incentives affect online product reviews and sales? http://aisel.aisnet.org/amcis2015/e-Biz/GeneralPresentations/35/

Pentina, I., Bailey, A. A., \& Zhang, L. (2015). Exploring effects of source similarity, message valence, and receiver regulatory focus on yelp review persuasiveness and purchase intentions. Journal of Marketing Communications, 1-21.

Petrescu, M., O’Leary, K., Goldring, D., \& Mrad, S. B. (2017). Five-Star Reviews: How Do Incentivized Product Reviews Impact Sales (An Abstract). In Marketing at the Confluence between Entertainment and Analytics (pp. 883-884). Springer, Cham.

Picazo-Vela, S., Chou, S. Y., Melcher, A. J., \& Pearson, J. M. (2010). Why provide an online review? An extended theory of planned behavior and the role of Big-Five personality traits. Computers in Human Behavior, 26(4), 685-696. 
Pinch, T., \& Kesler, F. (2011). How aunt Ammy gets her free lunch: A study of the top-thousand customer reviewers at amazon.com. Managing Overflow in Affluent Societies.

Pool, I. (1980). Comment on Mark Granovetter's" The strength of weak ties: A network theory revisited. In Annual Meetings of the International Communications Association, Acapulco, May.

PowerReviews. (2014). The Power of Reviews: How ratings and reviews influence the buying behavior of the modern consumer.

Pratt, M. G. (1998). Central questions in organizational identification. Identity in organizations, 171-207.

Prelinger, E. (1959). Extension and structure of the self. The Journal of Psychology, 47(1), 13-23.

Quester, P., \& Steyer, A. (2010). Revisiting Individual Choices in Group Settings: The Long and Winding (Less Traveled) Road?. Journal of Consumer Research, 36(6), 1050-1057.

Rayport, J. F., \& Sviokla, J. J. (1994). Managing in the Marketspace. Harvard Business Review, 72(6), 141-150.

Reed, A., Forehand, M. R., Puntoni, S., \& Warlop, L. (2012). Identity-based consumer behavior. International Journal of Research in Marketing, 29(4), 310-321.

Richins, M. L. (1983). Negative word-of-mouth by dissatisfied consumers: A pilot study. The Journal of Marketing, 68-78.

Richins, M. L. (1985). Factors affecting the level of consumer-initiated complaints to marketing organizations. Consumer Satisfaction, Dissatisfaction and Complaining Behavior, Bloomington, 82-85.

Richins, M. L. (1994). Valuing things: The public and private meanings of possessions. Journal of Consumer Research, 21(3), 504-521.

Richins, M. L., \& Chaplin, L. N. (2015). Material parenting: how the use of goods in parenting fosters materialism in the next generation. Journal of Consumer Research, $41(6), 1333-1357$.

Rodhain, A. (2006). Brands and the Identification Process of Children. Advances in Consumer Research, 33(1).

Rogers, E. M. (1962). Diffusion of innovations. Simon and Schuster. 
Schlosser, Ann E. (2011), "Can Including Pros and Cons Increase the Helpfulness and Persuasiveness of Online Reviews? The Interactive Effects of Ratings and Arguments," Journal of Consumer Psychology, 21 (3), 226-39.

Schmalz, S., \& Orth, U. R. (2012). Brand attachment and consumer emotional response to unethical firm behavior. Psychology \& marketing, 29(11), 869-884.

Scott, S. G., \& Lane, V. R. (2000). A stakeholder approach to organizational identity. Academy of Management review, 25(1), 43-62.

Sen, S., \& Lerman, D. (2007). Why are you telling me this? An examination into negative consumer reviews on the web. Journal of Interactive Marketing, 21(4), 7694.

Senecal, S., \& Nantel, J. (2004). The influence of online product recommendations on consumers' online choices. Journal of Retailing, 80(2), 159-169.

Sherif, M. (1936). The psychology of social norms.

Sheth, J. N. (1971). Word-of-Mouth in Lov Risk lnnovations. Journal of Advertising Research, 11(3), 15-18.

Shi, X., Adamic, L. A., \& Strauss, (2007). Networks of Strong Ties. Physica A: Statistical Mechanics and its Applications, 378(1), 33-47

Siebert, D. C., Mutran, E. J., \& Reitzes, D. C. (1999). Friendship and social support: The importance of role identity to aging adults. Social work, 44(6), 522-533.

Simons, H. W., Berkowitz, N. N., \& Moyer, R. J. (1970). Similarity, credibility, and attitude change: A review and a theory. Psychological Bulletin, 73(1), 1.

Simpkins, S. D., Parke, R. D., Flyr, M. L., \& Wild, M. N. (2006). Similarities in children's and early adolescents' perceptions of friendship qualities across development, gender, and friendship qualities. The Journal of Early Adolescence, 26(4), 491-508.

Stephen, A. T., Bart, Y., du Plessis, C., \& Gonçalves, D. (2012). Does paying for online product reviews pay off? The effects of monetary incentives on consumers' product evaluations. Papier de recherche, Insead, (2012/96).

Swanson, S. R., \& Kelley, S. W. (2001). Attributions and outcomes of the service recovery process. Journal of Marketing Theory and Practice, 9(4), 50-65.

Tajfel, H. E. (1978). Differentiation between social groups: Studies in the social psychology of intergroup relations. Academic Press. 
Tercia, C. Y., \& Teichert, T. (2017). How consumers respond to incentivized word of mouth: An examination across gender. Australasian Marketing Journal (AMJ), 25(1), 46-56.

Trenz, M., \& Berger, B. (2013). Analyzing Online Customer Reviews-An Interdisciplinary Literature Review And Research Agenda. In ECIS (p. 83).

Trump, R. K. (2014) 'Connected consumers' responses to negative brand actions: The roles of transgression self- relevance and domain', Journal of Business Research, 67(9), 1824-1830.

Tsiros, M., Mittal, V., \& Ross, W. T. (2004). The role of attributions in customer satisfaction: A reexamination. Journal of Consumer Research, 31(2), 476-483.

Tuškej, U., Golob, U., \& Podnar, K. (2013). The role of consumer-brand identification in building brand relationships. Journal of business research, 66(1), 5359.

Valle, V., \& Wallendorf, M. (1977). Consumers' attributions of the cause of their product satisfaction and dissatisfaction. Consumer Satisfaction, Dissatisfaction, and Complaining Behavior, 26-30.

Van Vaerenbergh, Y., \& Orsingher, C. (2016). Service Recovery: An Integrative Framework and Research Agenda. The Academy of Management Perspectives, 30(3), 328-346.

Voss, G. B., Parasuraman, A., \& Grewal, D. (1998). The roles of price, performance, and expectations in determining satisfaction in service exchanges. The Journal of Marketing, 46-61.

Wan, L. C., Hui, M. K., \& Wyer, R. S. (2011). The role of relationship norms in responses to service failures. Journal of Consumer Research, 38(2), 260-277.

Wang, G., Xie, S., Liu, B., \& Yu, P. S. (2012). Identify online store review spammers via social review graph. ACM Transactions on Intelligent Systems and Technology (TIST), 3(4), 61.

Wang, Y., \& Griskevicius, V. (2014). Conspicuous consumption, relationships, and rivals: Women's luxury products as signals to other women. Journal of Consumer Research, 40(5), 834-854.

Weiner, B. (1980). May I borrow your class notes? An attributional analysis of judgments of help giving in an achievement-related context. Journal of Educational Psychology, 72(5), 676.

Weiner, B., Russell, D., \& Lerman, D. (1978). Affective consequences of causal ascriptions. New Directions in Attribution Research, 2, 59-90. 
Wellman, B., \& Wortley, S. (1990). Different strokes from different folks: Community ties and social support. American journal of Sociology, 96(3), 558-588.

Werner, C., \& Parmelee, P. (1979). Similarity of activity preferences among friends: Those who play together stay together. Social Psychology Quarterly, 62-66.

White, K., Simpson, B., \& Argo, J. J. (2014). The motivating role of dissociative outgroups in encouraging positive consumer behaviors. Journal of Marketing Research, 51(4), 433-447.

Whyte Jr, W. H. (1954). The web of word of mouth. Fortune, 50(5), 140-143.

Wind, Y., Mahajan, V., \& Gunther, R. E. (2002). Convergence Marketing: Strategies for Reaching the New Hybrid Consumer Prentice-Hall. Englewood Cliffs.

Woodside, A. G., \& Davenport, J. W. (1974). The effect of salesman similarity and expertise on consumer purchasing behavior. Journal of Marketing Research, 11(2), 198-202.

Wojnicki, A. C., \& Godes, D. (2011). Signaling success: Strategically-positive word of mouth. In Working paper, Rotman School of Management, University of Toronto.

Wu, P. F. (2013). In search of negativity bias: An empirical study of perceived helpfulness of online reviews. Psychology \& Marketing, 30(11), 971-984.

$\mathrm{Xu}, \mathrm{Q}$. (2014). Should I trust him? The effects of reviewer profile characteristics on eWOM credibility. Computers in Human Behavior, 33, 136-144.

Yadav, M. S., \& Pavlou, P. A. (2014). Marketing in computer-mediated environments: Research synthesis and new directions. Journal of Marketing, 78(1), 20-40.

You, Y., Vadakkepatt, G. G., \& Joshi, A. M. (2015). A meta-analysis of electronic word-of-mouth elasticity. Journal of Marketing, 79(2), 19-39.

Zhang, J. Q., Craciun, G., \& Shin, D. (2010). When does electronic word-of-mouth matter? A study of consumer product reviews. Journal of Business Research, 63(12), $1336-1341$.

Zhao, M., \& Xie, J. (2011). Effects of social and temporal distance on consumers' responses to peer recommendations. Journal of Marketing Research, 48(3), 486-496.

Zhu, F., \& Zhang, X. (2010). Impact of online consumer reviews on sales: The moderating role of product and consumer characteristics. Journal of Marketing, 74(2), 133-148. 